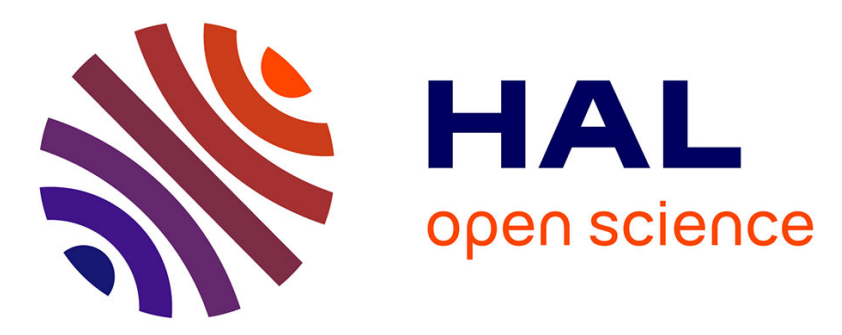

\title{
Assessing the conservation status of coastal habitats under Article 17 of the EU Habitats Directive
}

Pauline Delbosc, I. Lagrange, C. Rozo, F. Bensettiti, Jan-Bernard Bouzillé, D. Evans, A. Lalanne, Sébastien Rapinel, F. Bioret

\section{- To cite this version:}

Pauline Delbosc, I. Lagrange, C. Rozo, F. Bensettiti, Jan-Bernard Bouzillé, et al.. Assessing the conservation status of coastal habitats under Article 17 of the EU Habitats Directive. Biological Conservation, 2021, 254, pp.108935. 10.1016/j.biocon.2020.108935 . hal-03129871

\section{HAL Id: hal-03129871 \\ https://hal.science/hal-03129871}

Submitted on 29 Mar 2021

HAL is a multi-disciplinary open access archive for the deposit and dissemination of scientific research documents, whether they are published or not. The documents may come from teaching and research institutions in France or abroad, or from public or private research centers.
L'archive ouverte pluridisciplinaire HAL, est destinée au dépôt et à la diffusion de documents scientifiques de niveau recherche, publiés ou non, émanant des établissements d'enseignement et de recherche français ou étrangers, des laboratoires publics ou privés. 


\section{Assessing the conservation status of coastal habitats under Article 17 of the EU Habitats directive}

Pauline Delbosc ${ }^{a}$, Ilse Lagrange ${ }^{a}$, Clémence Rozo $^{\mathrm{b}}$, Farid Bensettiti ${ }^{\mathrm{c}}$, Jan-Bernard Bouzillé ${ }^{\mathrm{d}}$, Douglas Evans ${ }^{\mathrm{e}}$, Arnault Lalanne ${ }^{\mathrm{a}}$, Sébastien Rapinel ${ }^{\mathrm{b}}$, Frédéric Bioret ${ }^{\mathrm{a}}$

a Univ Brest, EA 7462 Géoarchitecture, F-29200 Brest, France.

${ }^{\mathrm{b}}$ LETG UMR 6554 CNRS, Université de Rennes, Place du recteur Henri Le Moal, 35043 Rennes, France.

${ }^{c}$ Muséum national d'Histoire Naturelle, UMS - PatriNat, 36, rue Geoffroy Saint-Hilaire - 75005 Paris, France.

d UMR CNRS 6553 Ecobio, OSUR Campus Beaulieu, Université de Rennes 1, France.

e Les Arolles, Route du Barry, 05260 St Léger les Mélèzes, France.

Corresponding author : delboscpauline@gmail.com,6 avenue Victor le Gorgeu, Institut de Géoarchitecture UFR Sciences, 29200 Brest CEDEX 3. 


\title{
1 Assessing the conservation status of coastal habitats under Article
} 17 of the EU Habitats directive

3

\begin{abstract}
Research on the habitats protected by the European Union's Habitats Directive (HD) has increased rapidly since its adoption in 1992. However, the methods and tools used to assess their conservation status are varied. In this context, we reviewed and summarized the scientific literature related to the coastal Natura 2000 habitats to list and sort parameters used to assess and map their conservation status. We found 225 papers that specifically focused on the assessment of conservation status of coastal habitats. An analysis of the papers was conducted based on the four parameters (range, area, structure and functions, future prospects) specified in the guidelines. Results highlight knowledge gaps regarding the availability of data and methods that measure the range, area, structure and functions and trends. Most of the papers focused on coastal dunes and were located in the Mediterranean biogeographic region. Therefore, the process of assessing the conservation status of coastal habitats remains complicated to implement because methodological approaches are mainly dominated by expert statements and all the procedures of the Habitats Directive are carried out within each member country and the final assessments are often the synthesis of these partial assessments. However, the multiscalar approach and the use of innovative technologies (databases, remote sensing) can be particularly relevant to develop replicable approaches and facilitate monitoring and the implementation of management measures.
\end{abstract}

Keywords: conservation status, coastal habitats, Habitats Directive, Natura 2000, European review.

\section{Introduction}

Coastal habitats are amongst the most threatened habitats and are subject to natural (marine and wind erosion) and anthropogenic pressures (climate change, urbanization, agriculture, tourism, etc.) (Heslenfeld et al., 2004; Jackson et al., 2011; Janssen et al., 2016). At the same time, awareness of their fragility has been heightened by regulatory protection measures and numerous studies on the geomorphological and temporal changes of coastlines, their management and development have been published (Brown and McLachlan, 2002 ; Sterr, 2008). It is critically important to find suitable monitoring methods which enable accurate information with a reasonable sampling effort. The implementation of the EU directives on the conservation of natural habitats and of wild fauna and flora (92/43/EEC) and on the conservation of wild birds (79/409/EEC) constitutes an important step towards the harmonization of nature conservation in the European Union. The aim of the Habitats Directive is to contribute towards ensuring bio-diversity through the conservation of natural habitats and of wild fauna and flora in the European territory of the Member States to which the Treaty applies and to maintain or restore in a favourable conservation status, natural habitats and species of wild fauna and flora of Community interest (Art. 2). The Birds and Habitats Directives require Member States to adopt the measures in the Directive and to actively implement them. The corresponding conservation actions focus on the "Species of Community Interest" and "Habitats of Community Interest" listed in the Annexes to the Directives. More specifically, the Habitats Directive (HD) requires Member States to monitor the conservation status of the habitats and species listed in the Directive (Art. 11) and to report periodically (Art. 17): conservation status of habitats and species must be assessed in a report every six years at the biogeographical level.

However, the implementation of the HD has been problematic as fundamental concepts used for reporting (Favourable reference values in particular) and the four parameters used to assess Conservation Status ("Range", "Area", "Structure and functions", "Future prospects") which are still unclear. In addition, monitoring protocols are difficult to standardise at biogeographical level due to the difference in data available between European countries and between habitats of Community interest (Evans, 2006; Maciejewski et al., 2016; Bijlsma et al., 2019). The general aims of the HD have not yet been achieved (EEA, 2015) and it is not possible to predict when, or if, they will be fully achieved. However, it is clear that the situation of habitats conserved by the Directives would be significantly worse in its absence and that the conservation status of habitats improves when targeted actions on a sufficient scale are taken (European Commission, 2016; Tucker et al 2019). Further research on monitoring and assessment of the conservation status of habitats is necessary to improve monitoring protocols and clarify the definitions of reference states and conservation status parameters (Angelini et al., 2018; Ellwanger et al., 2018). The Commission will present in 2021 a proposal to set legally binding nature conservation targets for the EU with a view to restoring degraded ecosystems, in particular, it will ask the 
Member States to ensure that trends in conservation and ecological status of all habitats and species are not deteriorated by 2030 (in connection with art. 11 and art. 17 of the HD) (European Commission, 2020).

Furthermore, the difficulties in implementing the HD at the national scale have an impact on the assessment of the conservation status at the local scale (within and outside Natura 2000 sites) but also on the monitoring of habitats. Indeed, the disparity of available scientific data and the diversity of methodological approaches do not allow for the effective implementation of conservation policies by managers. Moreover, local data represent a valuable source of information for testing and improving the methodological approach (Bensettiti and Trouvilliez, 2009). In this way, a multi-scalar scientific approach would answer the need for research set out in Art. 2 of the HD on the definition of the favourable conservation status, in Art. 11 of the HD on the monitoring of the conservation status and in Art. 17 on the assessment of the conservation status.

In this context, we carried out a review of the scientific literature at the European level in order to answer these two research questions : Q1-"Why and due to which aspects the implementation of HD remains complicated today to assess and monitor the conservation status ?"; Q2-"what are the most relevant and objective parameters to be implemented in the protocols for assessing and monitoring the conservation status of coastal habitats ?". We aimed (i) to examine the extent to which European Union countries have built their methodology to assess and monitor conservation status of coastal habitats; (ii) to examine which parameters and categories have been taken into account to assess and monitor conservation status of coastal habitat. To achieve this, we focused our research on publications dealing with the concepts of reference state and favorable conservation status as well as the assessment of the four parameters (range, area, structure and functions, future prospects) recommended by the guidelines of all coastal habitats of Appendix 1 of the Habitats Directive (dune, cliff, salt marsh, salt steppe, estuary and lagoon). Our review discusses the development of conservation status assessment projects with the aim of improving monitoring and management protocols. This paper constitutes a state of the art based on a European synthesis of methods for assessing the conservation status of coastal habitats. Beyond this methodological aspect, this synthesis allows to better define the context in which these methodologies are implemented and to identify research perspectives on the conservation assessment of coastal habitats.

\section{Methods}

We reviewed the literature according to the analytical framework proposed by Higgins and Green (2011), which is based on a standard protocol. Our aim was to trace a history and identify the methods and tools used to assess the current conservation status of coastal habitats. We have deliberately focused on the peer-reviewed literature but have also taken into account documents in the "grey literature" at a European scale (e.g. EEA and European Commission reports). We are aware that the assessment of the conservation status of habitats at the scale of Natura 2000 sites is frequently addressed in the grey literature (technical reports or synthesis). A literature search on the conservation status of all coastal habitat was performed with the SciVerse Scopus engine, arguably the largest database of peer-reviewed research literature. We used the main keywords as "conservation status" AND "Habitats Directive" AND ["coastal vegetation" OR “coastal habitat"] OR "Natura 2000" AND "Biodiversity" AND "Habitat conservation" AND "Habitat management" AND "Habitat type"). Although these terms are only in English, we have translated them into the main European languages (Italian, Spanish, French, Portuguese and German) in order to compile as many publications as possible from the different countries. Our study focuses on coastal terrestrial habitats in Appendix I of the Habitats Directive (Tab. C.1. in Appendix C). and does not cover species or the habitats of associated species. It also does not take into account publications dealing with ecosystem services (Drius et al., 2019) because this concept refers to the value (monetary or nonmonetary) of ecosystems. The final list of keywords contains the words most used in the literature and most representative, in order to collect the most records published on our subject of study. We conducted additional research on the assessment conservation status in different publication sources to obtain a maximum number of records. The time span of our search was 1992 - 2019 corresponding to the period since the Habitats Directive was adopted until now. Searches were carried out from March to May 2019.

After the elimination of duplicates, our initial search resulted in 352 records that were combined using Zotero software. To assess the accuracy of our search, we made a comparison with the first 50 records retrieved by Google Scholar. We found that we had already compiled the 50 records found on Google Scholar. We have removed from our initial data $(\mathrm{n}=352)$ those that do not deal with sensu-stricto research (in particular comments and supplements): (20), were not relevant to the Habitats Directive (45), concern species or the habitats of associated species (31), take into account publications dealing with ecosystem services (42), addressed areas outside the EU only (37), were not obtainable in full-text format (11), or did not fulfill our inclusion parameters for other reasons (duplicate publication (1)). The total number of papers retained for our analysis was 225 (Appendix A). 
A literature review was conducted to classify these 225 references retrieved during the search, and to extract the relevant information for testing our hypotheses. In order to assess the main references, parameters and criteria of the conservation status of coastal habitats, we read the whole text and for each paper we recorded the year of publications, type of research (quantitative and/or qualitative), biogeographical regions and countries where the study was conducted and their topic within predefined categories (Appendix B). First, we carried out a general characterization of the selected publications (typology used, type of habitat studied, spatial and temporal scale, types of surveys (quadrats, transects, phytosociological and/or landscape surveys...). Next, we carried out a content analysis to identify the methods and tools used in the literature to assess the status of the four parameters used to assess Conservation Status; "Range", "Area", "Structure and functions" and "Future prospects" (Evans \& Arvela 2011, Bijlsma et al. 2019). We have listed the number of records that use these keywords most frequently. We also classified the records according to their publication date. In addition, we sorted the studies according to the country and biogeographic regions where they were conducted in order to highlight geographic trends. Our research focused on specific topics among the most frequently addressed in order to detect other approaches used.

Descriptive statistics were used to assess the temporal trends of published papers. The proportion of records in relation to the total number of published records per year was also plotted as smoothed curves between 1992 (first record retrieved since adoption of the directive) and 2019. A Multiple Correspondence Analysis (MCA) was used to ordinate the similarities between the variables derived from our Literature review (Categories and classes - Tab. B.1. in Appendix B). In order to assess which methods have been used and at what scale, a MCA was applied to the categories "Types of surveys", "Spatial scale", "Range", "Area", "Structure and functions", and "Future prospects" (Tab. B.1. in Appendix B). Secondly and in view of the diversity of criteria used in the literature to assess the conservation status of the "Structure and functions" parameter, we sought to identify the proximities between the criteria and to count the records that take into account both one or more criteria using also MCA. All statistical procedures were conducted using the open source program R version 3.2.3 (R Core Team, 2014).

\section{Results}

\subsection{Overview and trends about conservation status approaches}

The conservation status of coastal habitats is a recent subject of study which has developed rapidly since the 2000s and particularly since 2011 (Figure 1 - [A]). The assessment of the conservation status seems to have evolved with computer science and mapping advances during this decade although red listing of plant communities/habitats/biotopes developed earlier (Janssen et al., 2016). Despite the adoption of the Habitats Directive in 1992, publications on coastal habitats did not appear in any number until the early 2000s, were frequent in the early 2000s, with a rapid increase in papers on the assessment of the conservation status of coastal habitats in the mid-2010s. However, there were many papers on the directive and Natura 2000 network in the 1990's but many were very general (eg Pott, 1997). Our overview shows that, in general, records on conservation status are carried out in a monitoring context rather than assessment context (Figure 1, [B]). Indeed, most studies have a focus on defining the conservation status to help managers recommend management measures adapted to the conservation of coastal habitats. This is particularly the case for long-term multitemporal analyses that have guided managers in planning conservation management strategies adapted to coastal dunes (Malavasi et al., 2013).

In general, the process of assessing the conservation status of coastal habitats remains difficult to implement for two reasons: on the one hand the methodological approach is mainly dominated by expert statements and on the other hand all the procedures of the Habitats Directive are carried out within each member country (individually) and the final assessments (at the biogeographic scale) are often the synthesis of these partial assessments. These aspects of the procedure imply disparities in the definition of the reference status, in the typologies used to describe the habitats to be assessed, and more broadly in the methods used to assess the conservation status according to coastal habitats (Bijlsma et al. 2019).

The fact that the EU Habitats Directive asks each country to define its reference states and its own criteria makes the standardization of protocols almost impossible: each country has its own protocols with the result that the approach differs from one country to another and by habitat type (Ellwanger et al., 2018). Definitions and concepts relating to the conservation status are still being debated in the scientific community today. There is no agreement on how to select typical species (of a habitat) (Gigante et al., 2018). This is reflected in our analyses by a small number of records published at European level (10\%). Generally speaking, the assessment of the conservation status is carried out at the local level (47\%) and very little at the national level (25\%). In some countries, the assessment of the conservation status at the national level is carried out by aggregating local data (within and outside N2000 sites) at the biogeographic level (Angelini et al., 2018). 
Numerous studies have been carried out to identify the components of coastal habitats using different typologies (Phytosociological typology, CORINE biotopes, EUNIS, EUR 28) (Figure 1, [D]). BraunBlanquetienne sigmatist phytosociology is the most widely used method to characterize their floristic composition and abiotic conditions for habitats (Dengler et al., 2008). However, this method remains based on experts' statements, which raises questions about the objectivity of the methodological approach.

Among coastal habitats, dune systems have been the subject of the largest number of studies (Fig. C.1. in Appendix C). Our analysis reveals a disparity in records between dunes and other coastal environments (eg cliffs, shingle, marshes and salt meadows) within Atlantic and Mediterranean biogeographic regions (Fig. C.1. in Appendix C). This is linked to the geomorphological context of this environment and the anthropogenic pressures (tourism, frequentation, trampling and urbanization) that make them very vulnerable (EEA, 2009; Ley de la Vega, 2012). In the other biogeographic regions, habitats are dealt with fairly equally. The analysis by country shows that dunes and salt meadows remain the most studied habitats. This analysis also shows that Italy and France are the two countries that have carried out the most studies on the assessment of the conservation status of coastal habitats (Fig. C.2. in Appendix C).

Even if today many techniques, such as numerical classifications or remote sensing represent relevant tools to standardize and objectify the process of assessing the conservation status of coastal habitats, they do not yet seem to be accepted by the procedure currently implemented.
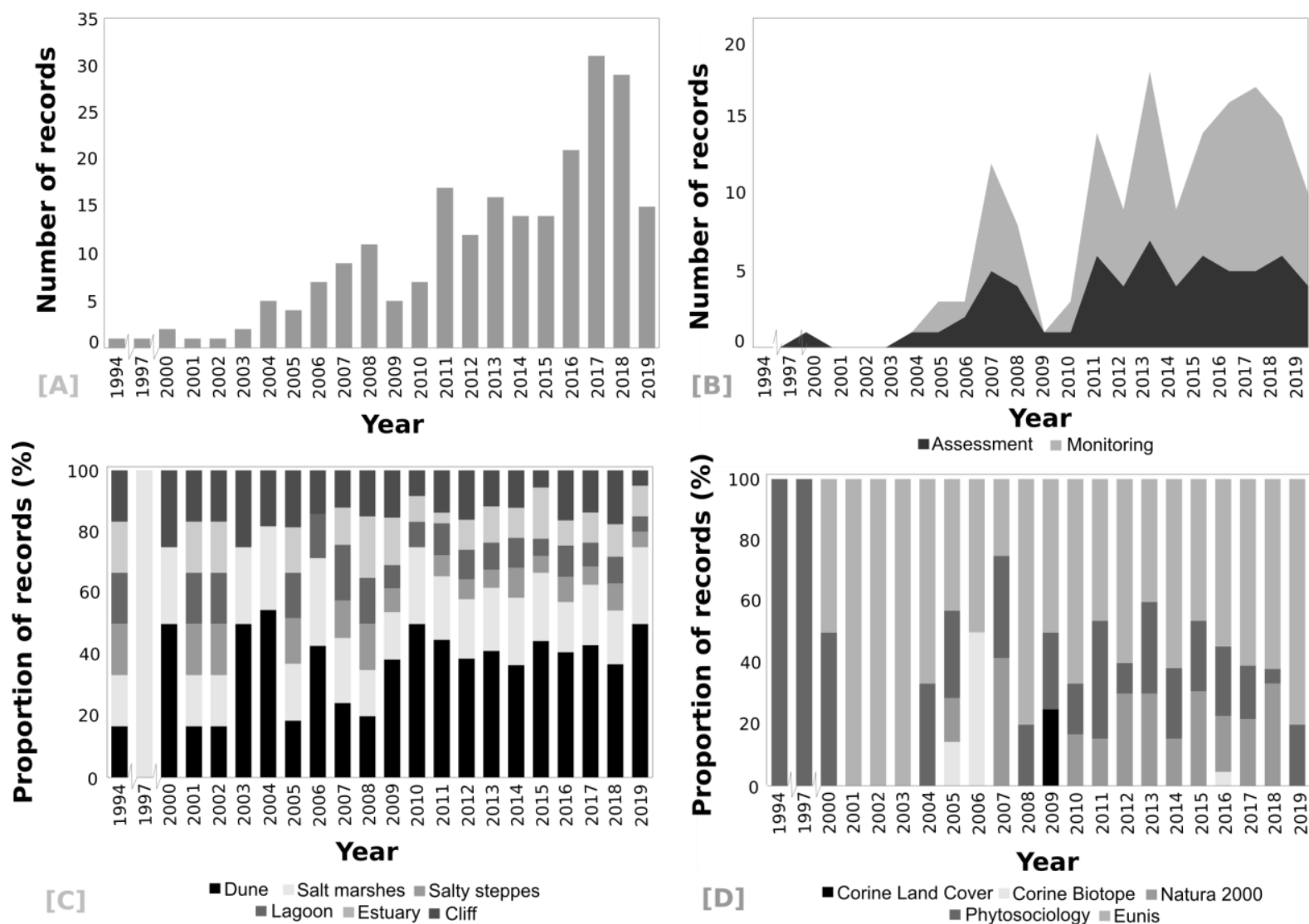

Figure 1. Temporal trends in the number of published records: (a) number of records concerning conservation status of coastal habitats ; (b) based on whether the studies focused on assessment of conservation status or on monitoring of conservation status ; (c) based on coastal habitats studied ; (d) based on typologies used to describe coastal habitats. Time frame: between 1994 (first record retrieved by our search) and 2019. The proportion of records of each classification in relation to the total number of published records per year was represented as column plots.

18 records deal with the use of databases to compile data for assessing conservation status (8\%). The use of databases has really developed since 2007 (Figure 2, [A]) with the aim of providing a tool for data processing using modern, digital methods for the phytosociological classification of vegetation. 98 records discuss mapping by field surveys and remote sensing (43\%). As in the case of databases, the use of GIS and remote sensing data has developed strongly since 2007 (Figure 2, [B]). 

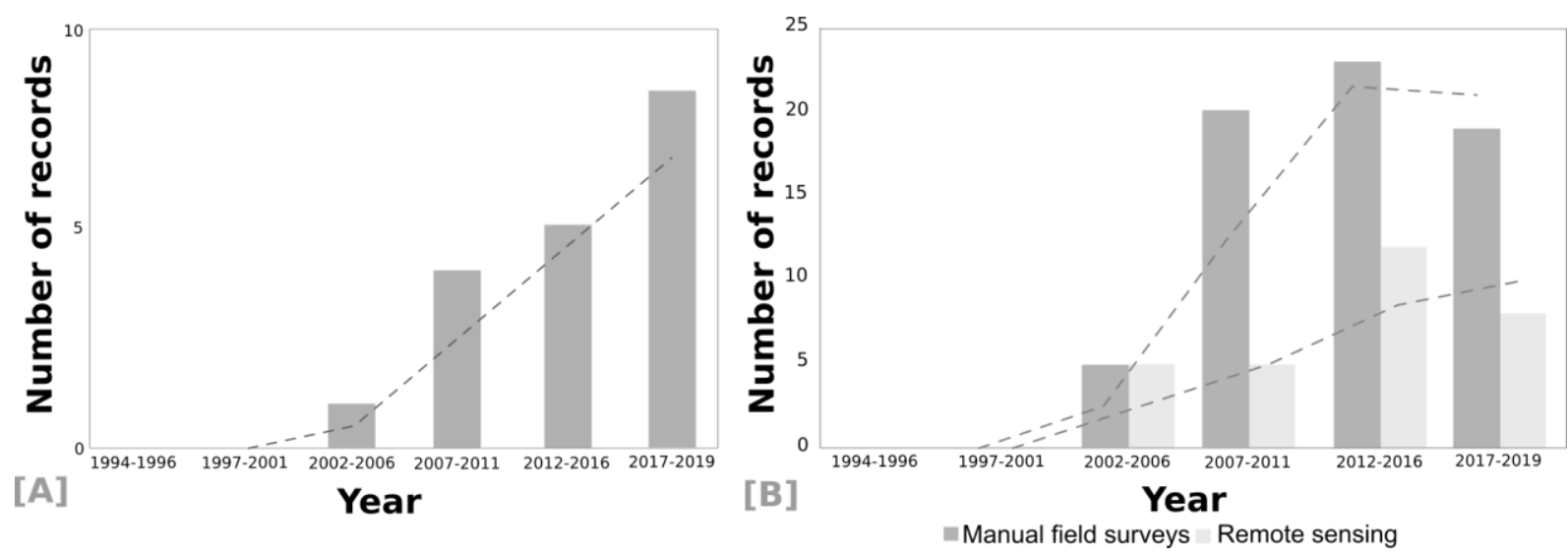

Figure 2. Temporal trends in the number of published records: (a) number of records using databases to assess conservation status of coastal habitats ; (b) based on whether the studies focused on assessment of conservation status using mapping and remote sensing approaches. For the outcomes of the literature review, the total number of records per year class [every 4 years] for each category was represented by line plots with smoothing curves for the period between 1994 (the first record retrieved by our search) and 2019.

\subsection{Trends in assessing the conservation status of parameters}

Since 2007, there has been a significant increase in the number of records on tools and methods to evaluate these parameters (Fig. D.1. in Appendix D). 216 publications deal with the assessment of at least one of the 4 parameters defined in Art. 17 of the HD. 81 records discuss "Area," 114 records deal with "Range," 196 records focus on "Structure and functions," and 134 discuss "Future prospects. "Structure and functions" is the parameter with the most records since 2006 while "Future prospects" has been the subject of more publications since 2011. On the other hand, the number of publications concerning the parameters "Range" and "Area" has shown a less significant increase since 2010: "Range" is discussed in an average of 15 publications per year and "Area" in 6 publications per year. This result contrasts with the other two parameters which are discussed on average in 25 publications per year for "Future prospects" and 38 publications per year for "Structure and functions".

Figure 3 show the main methodological approaches and study scales are used to assess and monitor the conservation status of coastal habitats.

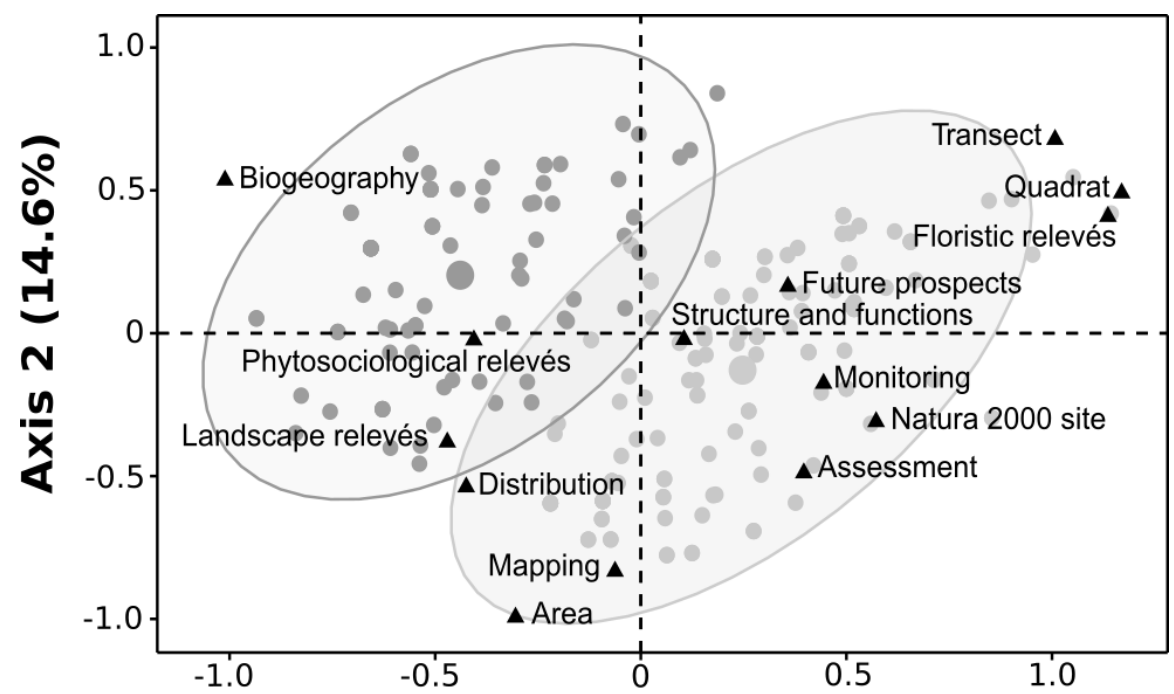

Axis $1(18.2 \%)$

Figure 3. Ordination of methodological approaches and scales used to assess the conservation status of coastal habitats. Multiple Correspondence Analysis (MCA) of the records classified according to "Spatial Scale" [Natura 2000 site, Biogeography], "Types of surveys" [Quadrat, Transect, Floristic relevés, Phytosociological relevés, Landscape relevés, Mapping], "Parameters [Range, Area, Structure and functions and Future prospects] and "type of contribution" [Assessment, Monitoring]. Time-period: 1994-2019. Number of records: 225. Values in brackets refer to the amount of variance explained by MCA axes 1 and 2 . 

an ellipse: the first ellipse (leftmost) represents an approach at the regional scale based on phytosociological and landscape relevés; the second ellipse represents an approach at the local scale in a context of monitoring and management of coastal habitats. This second ellipse (rightmost) highlights a diversity of survey types to assess the conservation status of the four parameters: mapping is used to assess the "Range" and "Area" parameters, while quadrats, transects and floristic relevés are used to assess the "Structure and functions" and "Future prospects" criteria. Early studies focused on reflections on assessment systems and more specifically on the criteria that could be taken into account to evaluate the degree of artificialization and naturalness (e.g. Loidi, 1994). Nowadays, methodological approaches are more oriented towards numerical and statistical models to assess the conservation status of coastal habitats. This is particularly the case on the Adriatic coast where mapping data and analyses of floristic and phylogenetic composition have been carried out to understand the impact of tourism on dune habitats (e.g. Šilc et al., 2019).

Range represents the envelope within which the areas actually occupied by a habitat type occur. The aim of this parameter is to describe and detect changes in the extent of the distribution. 114 records discuss range: $42 \%$ (48 records) focus on the biogeographic level and 58\% (67 records) of them at the Natura 2000 site level. The most commonly used method for obtaining habitat range maps is geo-referenced phytosociological relevés (52\% - 60 publications) followed by mapping methods (Habitat maps and remote sensing; $36 \%$ - 41 records). From our research, 55\% of the records (63 records) use the EUNIS typology, followed by Annex I (17.5\% - 20 records) and syntaxonomic (16.6\% - 19 records) typologies. Dune systems (80\% - 92 records), salt meadows (61 records) and cliffs (44 records) are the coastal habitats most frequently studied. This parameter has to be assessed at the biogeographic scale (Del Vecchio et al., 2017). Our results showed that the methods for assessing the Favourable Reference Range of coastal habitats are based on two approaches: (i) an historical approach based on diachronic analysis. This approach studies the historical range of a habitat at a time when it was supposed to be in a favourable conservation status. (ii) A modeling approach based on "species range models" (SDMs). This approach allows the relationship between habitats and abiotic variables to be analyzed to predict their range where in situ data are missing.

Area represents the occupied surface in $\mathrm{km}^{2}$ of a habitat type. 81 records (36\% of all selected records) discuss "Area". 33\% (27 records) on the parameter at the biogeographic scale and 67\% (55 records) at the Natura 2000 site scale. The most commonly used method to obtain habitat area is mapping (53\% - 43 publications) or by remote sensing ( $26 \%$ - 21 records). To monitor the changes in area over time and space, diachronic analysis are mainly used (21\% - 17 publications). From our research, $48 \%$ of the records (39 records) use the EUNIS typology, followed by Natura 2000 (24.6\% - 20 records) and syntaxonomic (17.3\% - 14 records) typologies. Dune systems ( $72.8 \%$ - 59 records), salt meadows $(60.5 \%$ - 49 records) and cliffs $(43 \%-35$ records) are the coastal habitats whose distribution has most frequently been studied.

Structure is defined by the physiognomy of the dominant species that make up the habitat and abiotic features: Function is defined by the essential ecological processes that occur internally and may include physical processes (e.g. dune formation and erosion). This parameter is the most studied (205 records), its evaluation is carried out, essentially at the level of Natura 2000 sites (68\% - 140 publications). Figure 4 shows three main approaches to assess the conservation status of the "Structure and functions" parameter: (i) the first ellipse (leftright) represents dynamic-geomorphological approach (to study ecological erosion and landscape fragmentation); (ii) the second ellipse (bottom left) concerns phytosociological scale (to identify plant communities contained in habitat and their dynamic trajectories; (iii) the third ellipse (top left) represents a species scale (to define the typical species, the presence or absence of alien species, the floristic composition or functional traits).

Two approaches with different characteristics are highlighted (Figure 4). Each approach corresponds to an ellipse: the first ellipse (leftmost) represents an approach at the regional scale based on phytosociological and landscape relevés; the second ellipse represents an approach at the local scale in a context of monitoring and management of coastal habitats. 


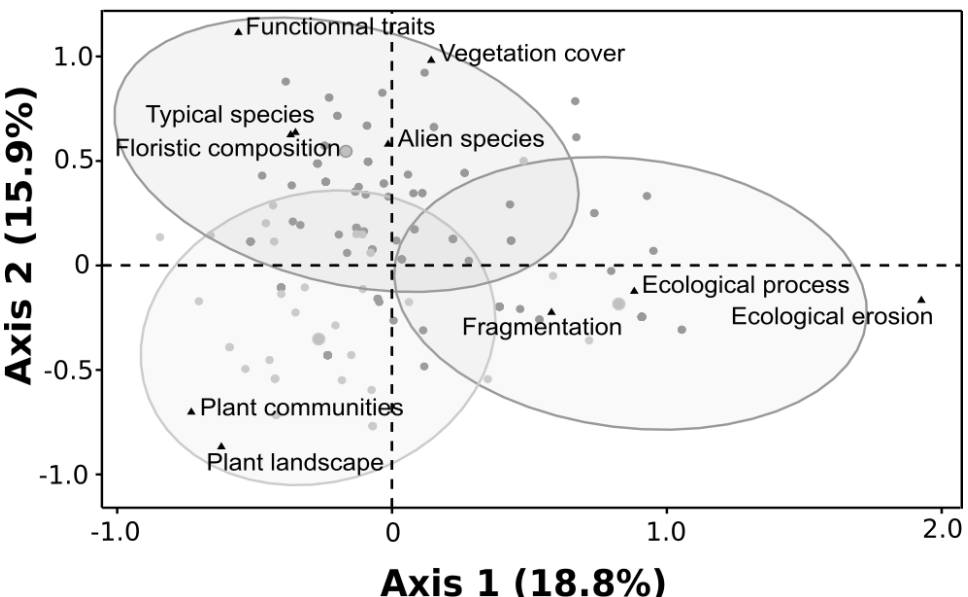

Axis 1 (18.8\%)

Figure 4. Distribution of the criteria used to evaluate the parameter "Structure and functions". Multiple Correspondence Analysis (MCA) of records classified according to "Plant landscape", "Plant communities composition", "Functionnal traits", "Vegetation cover", "Alien species", "Floristic composition", "Typical species", "Fragmentation", "Ecological process", "Ecological erosion". Time period: 1997-2019. Number of records: 191.

Future prospect is not defined in the Directive but it is recommended to be assessed by considering the future trends and likely future status of the three other parameters (Range, Area, Structure and functions). 138 records (61\% of all selected records) cover the parameter "Future prospects". Future prospects of each of the three parameters (Range, Area, and Structure and functions) should mainly reflect the future trends which are based on a comparison of pressures and conservation measures (DG Environment, 2017). However, in most of the records in our review the method used is based on two main approaches: (1) the typology based on a list of threats observed on studies areas and (2) diachronic analysis to define past and current trends in habitat evolution (Valentini et al., 2015; Diez-Garretas et al., 2019).

\section{Discussions}

We have reviewed the literature on aspects related to the application of the Habitats Directive in assessing the conservation status of coastal habitats. Our aim was to identify important trends and research gaps. Our results showed (1) an increase in the number of publications on conservation status assessment over time, mainly from 2011 onwards; (2) a bias according to the coastal habitats studied as $80 \%$ of the publications focus on dune systems ; (3) a strong geographical bias, most of the scientifically published research being carried out in two biogeographical regions (Atlantic and Mediterranean) and in two countries (Italy and France); (4) that the conservation status is based on the assessment of 4 parameters recommended by the guidelines (Range, Area, Structure and functions, Future prospects); (5) that the definitions of these 4 parameters lack clarity and imply a diversity of methodological approaches which are against a standardised protocol; (6) that even if there are tools and methods (e.g. numerical classification and remote sensing) which would favour the standardisation of a protocol, the current procedure is essentially based on expert judgements and the summaries on a biogeographical scale are only a partial synthesis of the reality on the ground.

One of the most striking results is the lack of comparability in the definition of concepts and especially for the definition of the reference state (Bijlsma et al. 2019). The European Commission asks each Member State to define the reference state of habitats and the criteria used to assess the conservation status parameters. Thus, each European country defines its own reference states, thus creating two major problems: on the one hand, the lack of conceptual and methodological coherence between European countries, methodological transposition problems from one country to another and a non-standardized habitat assessment on a biogeographic region at European scale. Reference states will be unique to each country but it is necessary that the methods used to define them are compatible.

In France, for example, the reference state can be defined from a "natural" or "semi-natural" state, i.e. not disturbed by human activities, but it can also mean the best existing or achievable state in a given space where man is considered as a whole in the ecosystem (Maciejewski et al., 2016). Given the anthropogenic activities that have significantly altered natural environments, the definition of the reference state is delicate, a widely applied solution is to do the opposite, i.e. define a state of degradation (Janssen et al., 2016).

Although Art. 17 uses the term 'Favourable Conservation Status' and it is to be used for Art 17 reporting, multi-scale and temporal monitoring of habitats is an approach that would allow us to move away 
from the concept of a reference state and evaluate "favourable" or "unfavourable" conservation status while having an assessment of the changes taking place in the plant landscape. The development of partnerships between academics and managers will facilitate the implementation of monitoring protocols adapted to the scale of Natura 2000 sites and according to the habitats of Community interest. From these various follow-ups, it will then be possible to identify trends and changes at the biogeographic scale when the Natura 2000 network covers most of the habitat within the region being assessed. The feasibility of this approach will depend on time, available data resources (manpower, finance ....).

The definitions of the four parameters and their methodologies remain fairly fuzzy. This lack of clarity favours the multiplication of methodological approaches that make it difficult to standardize a protocol.

Moreover, the syntheses for assessing the conservation status of these four parameters at the biogeographic scale come from syntheses of data produced at local scales (sites) that differ from one habitat to another, from one country to another and from one biogeographic region to another. This synthesis is therefore a partial evaluation of the conservation status and not very representative of all the regions.

Many authors note the difficulty of assessing "Range" for two reasons: (i) the lack or absence of data on certain habitats (Gigante et al., 2016); (ii) the need to have survey data to assess this parameter (Prisco et al., 2012; Chytrý et al., 2016). The spatial range of habitats is generally represented by maps of plant communities at different scales. The combination of ecological modelling and remote sensing offers many advantages over field investigations and image interpretation, thus harmonizing and standardizing maps of current and potential habitat range within biogeographic regions (Álvarez-Martínez et al., 2017). Field mapping of habitats remains an expensive and time-consuming method that can only be carried out at a large scale. The other problem with the field maps currently being produced is based on the share of subjectivity in habitat delineation: each observer has his or her own vision. This observation implies the need to promote mapping methods that can be transposed and repeated from one site to another (Ichter et al., 2014). Remote sensing is increasingly used to automate habitat mapping, especially when combined with other datasets (eg geology, digital terrain models), but these techniques, which are currently being developed, are not widely used (Borre et al., 2017; Agrillo et al., 2018). This method should be more objective and repeatable than field mapping. Some authors propose to use old satellite images to establish a surface reference state (Cabello et al., 2018) and to do diachronic analysis in time and space (Valentini et al., 2015) but these approaches are carried out at coastal site scales (Tomaselli et al., 2012).

The definition and the assessment of Structure and functions is based on expert knowledge. At present, there is no standardised protocol for its assessment at local level and comparison at national and biogeographic levels. This standardization is difficult to achieve because each state agency uses its own criteria (Figure 5). "Typical species" is considered as one of the main criteria for assessing the status of Structure and functions. There is no agreement on the definition of typical species, no univocal vision of the situation currently exists but this notion is often discussed in the publications. Typical species for Art 17 reporting are those which mainly occur in a habitat type or at least in a subtype or a variant of a habitat type (European Commission, 1992; DG Environment, 2017). In this context, the concept of 'diagnostic species composition', a kind of 'reference state' (Gigante et al., 2016), becomes central. Two approaches can be distinguished to define "Typical species": the first is based on the definition of "faithful" or "diagnostic" species that are strictly linked to one habitat and cannot be found in another (Chytrý et al., 2002); the second is based on "sentinel" species which constitute a criteria of artificialization or environmental degradation (Caro, 2010). Gigante et al. (2018) propose to integrate the entire floristic pool into the assessment of the conservation status of the "Structure and function" parameter in order to have a vision that is as representative as possible of the habitat. However, DG Environment (2017) specifies that typical species indicate favourable habitat quality. Thus, by definition, typical species cannot include those that indicate degradation. On the other hand, the development of databases allows a better understanding of the structure and functioning of habitats (Chýtrý et al. 2016) and facilitates the crosswalks between the different typologies (Rodwell et al. 2018).

Future prospects is the parameter with the most variation in approaches. In most studies, the evaluation of this parameter is based on a qualitative analysis based on a typology of threats to habitats (Pakeman et al., 2017; Bezzi et al., 2018). Several indexes have been set up to assess the vulnerability of habitats (Williams et al., 2011; Ciccarelli et al., 2017), their naturalness (Boteva et al., 2004), their resilience (Garcia-Lozano et al., 2018) or their degree of artificialisation (Pinna et al. 2015; Tsiripidis et al., 2018). Future prospects requires consideration of future trends in all three parameters: range, area, structure and functions, in relation to the current conservation status (DG Environment, 2017). This parameter should best reflect management methods in favour of the conservation of coastal habitats but also anticipate global changes (climate change, land-use scenarios and trends in certain policies) which are aspects that will influence future trends and which will involve their deterioration. The assessment of this parameter takes time and on coastal areas the time required for the survey depends on several variables such as the morphological complexity of the area, its accessibility, the complexity of the vegetation mosaic and the competence of the field operator (Del Vecchio et al., 2019). Future 
prospects must be developed to detect the level of pressure currently exerted on the habitat but also to quickly detect potential impacts to support management measures to mitigate and treat impacts on habitats. Innovative technologies such as remote sensing could be used to assess changes in critical habitat functions related in part to species distribution. Overall, these contributions of remote sensing are of the utmost importance not only to monitor invasions, but also to mitigate, restore and improve environmental quality, adapt to their potential impacts (Simberloff et al., 2013). Moreover, the functional traits of species are increasingly being used to highlight changes and functional divergences between coastal habitats (eg embryo dunes vs fixed dunes) (Torca et al., 2019). In particular, the functional traits of typical species are studied to better understand functional characteristics (plant height, specific leaf area, leaf dry matter content, leaf size, leaf thickness, seed mass, seed shape) and the strategies adopted by plants in response to disturbances (Jiménez- Alfaro et al., 2015; Mahdavi and Bergmeier, 2016). Plot monitoring to follow changes in specific composition can be used to quantify temporal changes in species composition (Sperandii et al., 2019). Despite being challenging and time consuming, revisitation studies are highly recommended tools for analyzing temporal dynamics in plant communities (Del Vecchio et al., 2019).

Finally, approaches to assess the conservation status of these four parameters should draw from the Red Lists of species and habitats, particularly to assess and monitor habitat loss and fragmentation (Brooks et al., 2019) but also from Essential Biodiversity Variables, which aim to monitor ecosystems based on standardized variables (Pettorelli et al., 2016).

Our results show that there is a real disparity in studies concerning coastal habitats. Indeed, among all coastal habitats, dunes are the most studied environments and the most taken into account in conservation status assessment studies (80\% of the studies we examined concern dune systems), particularly within the Atlantic and Mediterranean biogeographical regions. Dunes are the most vulnerable habitats to human and natural pressures. In general, dunes have an essential buffer role against storms and inland habitats (McLachlan \& Brown, 2006), a role that can be limited when they are disturbed (frequentation, alien species...). Thus, given the important conservation issues, numerous legislative measures have been implemented to protect them on a global scale (Heslenfeld et al., 2004). Assessment of Range and Area are the two most studied parameters for all coastal habitats. However, for the parameters Structure and function and Future prospects, disparities exist between habitat types. Indeed, the analysis of the literature shows that the trend is more towards a phase of learning and understanding the structure (physiognomy, dynamics) and functioning (ecological and anthropogenic processes) of habitats than an evaluation phase. This trend is largely explained by the recent increase (since 2012) of methodological approaches that are being implemented to improve knowledge on the different types of coastal habitats, especially on the most threatened habitats. It is on the basis of this knowledge and long-term monitoring data that it will be possible to determine the optimal state of structure and functioning of each habitat. A rebalancing of studies on all habitats (salt steppes, lagoons, cliffs, etc.) would provide an overall picture of the conservation status of all coastal habitats. Our review shows the need for interdisciplinary work: most studies focus either on ecological processes or on floristic and vegetation aspects (floristic and phytosociological approach) or on range and area aspects (spatial approach). No current studies have combined all of these aspects for the same habitat. The development of a multidisciplinary approach would make it possible to integrate all the knowledge needed to assess the conservation status of habitats in an integrated and effective way. This approach can improve preventive actions against threats to habitats that contribute to maintaining their functionality (Attorre et al., 2018; Rodwell et al., 2018).

\section{Conclusions}

We have reviewed and discussed the methods and tools that are used in the literature to assess the conservation status of coastal habitats in Europe. Indeed, although HD implies assessing of 4 parameters (Range, Area, Structure and functions, Future prospects) it does not require any agreed methodological approaches, which raises real difficulties for the actors who are led to assess the conservation. The procedure currently being implemented is essentially based on expert judgements and is carried out by each country. Thus, the assessment of the state of conservation at the biogeographic scale is a synthesis of these partial assessments. The application of HD currently remains very disparate from one biogeographic region to another, from one country to another and from one habitat to another. Many studies have been carried out in the Atlantic and Mediterranean regions, mainly in Italy and France, and most of them concern dune systems representing the most threatened environments. These divergences are closely linked to the lack of clear and precise definitions of the main concepts (reference status, typical species and parameters in particular) which are still debated among scientists but also to the lack of available data. Most of the methods currently used in the literature are limited by the available data, which do not currently allow a multi-scalar and spatial view of the assessment of the conservation status of coastal habitats. 
Despite the constraints we have identified, interest in assessing the conservation status of coastal habitats has become prevalent over the past decade. There has been a significant increase in work on various types of coastal habitats (cliffs, lagoons, salt steppes, salt meadows, dunes), advancing interdisciplinary strategies for more effective protocol implementation and habitat conservation status monitoring. With regard to all the records analysed, the aims are to promote (i) recent and innovative methods for automatic and objective modelling of habitat range and area; (ii) pragmatic protocols applicable by all Natura 2000 site managers for assessing and monitoring the conservation status; and (iii) a concerted and multiscalar management strategy. Measures could be taken to change this situation: for example, the use of databases would help to structure and standardise data and promote exchange between actors; experimental monitoring investigations should be encouraged to gain a more accurate picture of changes and trends in habitats, particularly in the context of global changes.

\section{Acknowledgments}

We thank the editor and reviewers for their advice which helped improve this paper.

\section{Declaration of competing interest}

The authors declare that they have no known competing financial interests or personal relationships that could have appeared to influence the work reported in this paper.

\section{Appendix}

Appendix A - Publications included in our in-depth review (225 publications, period 1992-2019).

Appendix B - Keywords selection protocol and literature search criteria

Appendix C - Typology and distribution of the number of publications concerning coastal habitats by biogeographic region and by European countries.

Appendix D - Supplementary analysis.

\section{References}

Agrillo, E., Alessi, N., Jiménez-Alfaro, B., Casella, L., Angelini, P., Argagnon, O., Crespo, G., Fernández-González, F., Monteiro-Henriques, T., Silva Neto, C., Attorre, F., 2018. The use of large databases to characterize habitat types: the case of Quercus suber woodlands in Europe. Rendiconti Lincei. Scienze Fisiche e Naturali. 29, 2, 283

293. https://doi.org/10.1007/s12210-018-0703-x

Álvarez- Martínez, J.M., Jiménez- Alfaro, B., Barquín, J., Ondiviela, B., Recio, M., Silió- Calzada, A., Juanes, J.A., 2017. Modelling the area of occupancy of habitat types with remote sensing. Methods in Ecology and Evolution. 9, 3, 580593. https://doi.org/10.1111/2041-210X.12925

Angelini, P., Chiarucci, A., Nascimbene, J., Cerabolini, B.E., Dalle Fratte, M., Casella, L., 2018. Plant assemblages and conservation status of habitats of Community interest (Directive 92/43/EEC): definitions and concepts. Ecological Questions. 29, 3, 87-97. http://dx.doi.org/10.12775/EQ.2018.025

Attorre, F., Pignatti, S., Spada, F., Casella, L., Agrillo, E., 2018. Introduction: Vegetation science and the habitats directive: approaches and methodologies of a never-ending story. Rendiconti Lincei. Scienze Fisiche e Naturali. 29(2), 233-235. https://doi.org/10.1007/s12210-018-0716-5

Bensettiti, F., Trouvilliez, J., 2009. Rapport synthétique des résultats de la France sur l'état de conservation des habitats et des espèces conformément à l'article 17 de la directive habitats. Rapport SPN 2009/12, MNHN-DEGB-SPN, Paris, pp. 48. Bezzi, A., Pillon, S., Martinucci, D., Fontolan, G, 2018. Inventory and conservation assessment for the management of coastal dunes, Veneto coasts, Italy. Journal of Coastal Conservation. 22, 503-518. https://doi.org/10.1007/s11852-017-0580y

Bijlsma, R.J., Agrillo, E., Attorre, F., Boitani, L., Brunner, A., Evans, P., Foppen, R., Gubbay, S., Janssen, J.A.M., Van Kleunen, A., Langhout, W., Pacifici M., Ramírez, I., Rondinini, C., Van Roomen, M., Siepel, H., Van Swaaij, C.A.M., Winter, H.V., 2019. Defining and applying the concept of Favourable Reference Values for species habitats under the EU Birds and Habitats Directives: examples of setting favourable reference values (No. 2929). Wageningen Environmental Research, Wageningen, pp. 92.

Borre, J.V., Spanhove, T., Haest, B., 2017. Towards a mature age of remote sensing for Natura 2000 habitat conservation: Poor method transferability as a prime obstacle, in: Díaz-Delgado R., Lucas R., Hurford C. (eds) The Roles of Remote Sensing in Nature Conservation. Springer, Cham. https://doi.org/10.1007/978-3-319-64332-8_2

Boteva, D., Griffiths, G., Dimopoulos, P. 2004. Evaluation and mapping of the conservation significance of habitats using GIS: an example from Crete, Greece. Journal for Nature Conservation. 12, 237-250.

https://doi.org/10.1016/j.jnc.2004.09.002

Brooks, T. M., Pimm, S. L., Akçakaya, H. R., Buchanan, G. M., Butchart, S. H. M., Foden, W., (...) Rondinini, C., 2019, November 1). Measuring terrestrial area of habitat $(\mathrm{AOH})$ and its utility for the IUCN Red List. Trends in Ecology \& Evolution, 34, 977-986. https://doi. org/10.1016/j.tree.2019.06.009 
Brown, A.C., McLachlan, A., 2002. Sandy shore ecosystems and the threats facing them: some predictions for the year 2025. Environmental Conservation. 29, 62-77. https://doi.org/10.1017/S037689290200005X

Cabello, J., Mairota, P., Alcaraz-Segura, D., Arenas-Castro, S., Escribano, P., Leitão, P.J., Martínez-López, J., Regos A., Requena-Mullor, J.M., Satellite Remote Sensing of Ecosystem Functions: Opportunities and Challenges for Reporting Obligations of the EU Habitats Directive. In: IGARSS 2018-2018 IEEE International Geoscience and Remote Sensing Symposium. IEEE, 6604-6607. https://doi.org/10.1109/IGARSS.2018.8517296

Caro, T., 2010. Conservation by proxy: indicator, umbrella, keystone, flagship, and other surrogate species. Island Press. Washington, pp. 374.

Chytrý, M., Hennekens, S.M., Jiménez- Alfaro, B., Knollová, I., Dengler, J., Jansen, F., (...) \& Yamalov, S., 2016. European Vegetation Archive (EVA): an integrated database of European vegetation plots. Applied vegetation science. 19, $173-180$. https://doi.org/10.1111/avsc. 12191

Chytrý, M., Tichý, L., Holt, J., Botta- Dukát, Z., 2002. Determination of diagnostic species with statistical fidelity measures. Journal of Vegetation science. 13, 79-90. https://doi.org/10.1111/j.1654-1103.2002.tb02025.x

Ciccarelli, D., Pinna, M.S., Alquini, F., Cogoni, D., Ruocco, M., Bacchetta, G., Sarti, G., Fenu, G., 2017. Development of a coastal dune vulnerability index for Mediterranean ecosystems: A useful tool for coastal managers? Estuarine, Coastal and Shelf Science. 187, 84-95. https://doi.org/10.1016/j.ecss.2016.12.008

Del Vecchio, S., Fantinato, E., Silan, G., Buffa, G., 2019. Trade-offs between sampling effort and data quality in habitat monitoring. Biodiversity and conservation. 28(1), 55-73. https://doi.org/10.1007/s10531-018-1636-5

Del Vecchio, S., Fantinato, E., Janssen, J.A.M., Bioret, F., Acosta, A., Prisco, I., Tzonev, R., Marcenò, C., Rodwell, J., Buffa, G., 2017. Biogeographic variability of coastal perennial grasslands at the European scale. Applied Vegetation Science. 21, 312-321. https://doi.org/10.1111/avsc. 12356

Dengler, J., Chytrý, M.,Ewald, J. 2008. Phytosociology, in: Jørgensen S.E., Fath B.D. (eds.), General Ecology. Vol. 4 of Encyclopedia of Ecology, Elsevier, Oxford, pp. 2767-2779.

DG Environment, 2017. Reporting under Article 17 of the Habitats Directive: Explanatory notes and guidelines for the period 2013-2018. Final version - May 2017. Brussels, pp. 188. http://cdr.eionet.europa.eu/help/habitats_art17/index_htm

Díez-Garretas, B., Comino, O., Pereña, J., Asensi, A., 2019. Spatio-temporal changes (1956-2013) of coastal ecosystems in Southern Iberian Peninsula (Spain). Mediterranean Botany. 40, 111-119. https://doi.org/10.5209/MBOT.62889

Drius, M., Jones, L., Marzialetti, F., de Francesco, M.C., Stanisci, A., Carranza, M.L., 2019. Not just a sandy beach. The multi-service value of Mediterranean coastal dunes. Science of the total environment. 668, 1139-1155.

https://doi.org/10.1016/j.scitotenv.2019.02.364

Ellwanger, G., Runge, S., Wagner, M., Ackermann, W., Neukirchen, M., Frederking, W., Müller, C., Ssymank, A., Sukopp, U., 2018. Current status of habitat monitoring in the European Union according to Article 17 of the Habitats Directive, with an emphasis on habitat structure and functions and on Germany. Nature Conservation. 29, 57-78. https://doi.org/10.3897/natureconservation.29.27273

Evans, D., 2006. The Habitats of the European Union Habitats Directive. Biology and Environment: Proceedings of the Royal Irish Academy. 106, 167-173. https://doi.org/10.3318/BIOE.2006.106.3.167

Evans, D., Arvela, M., 2011. Assessment and reporting under Article 17 of the Habitats Directive. Explanatory Notes \& Guidelines for the period 2007-2012. European Commission, Brussels, pp. 123.

European Commission, 1992. Council Directive 92/43/EEC of 21 May 1992 on the conservation of natural habitats and of wild fauna and flora. Official Journal 206: 7-50. http://eur-

lex.europa.eu/LexUriServ/LexUriServ.do?uri=CELEX:31992L0043:EN:HTML

European Commission, 2016. Commission Staff Working Document: Fitness Check of the of the EU Nature Legislation (Birds and Habitats Directives) Directive 2009/147/EC of the European Parliament and of the Council of 30 November 2009 on the Conservation of Wild Birds and Council Directive 92/43/EEC of 21 May 1992 on the Conservation of Natural Habitats and of Wild Fauna and Flora (SWD(2016) 472 Final). European Commission, Brussels. http://eurlex.europa.eu/legalcontent/EN/TXT/PDF/?uri=CELEX:02009L0147-20130701\& qid=1506451801028 \& from=EN. European Commission, 2020. Communication de la Commission au Parlement Européen, au Conseil, au Comité économique et social européen et au Comité des Régions. Stratégie de l'UE en faveur de la biodiversité à l'horizon 2030. Technical Report No. 5/2020. https://eur-lex.europa.eu/legal-content/FR/TXT/?uri=CELEX\%3A52020DC0380

European Environment Agency, 2009. Article 17 Technical report (2001-2006). Brussels, Belgium.

https://www.eionet.europa.eu/etcs/etc-bd/activities/reporting/article-17/outcomes-2001-2006

European Environment Agency (EEA), 2015. State of Nature in the EU. Results from Reporting Under the Nature Directives 2007-2012. Technical Report No. 2/2015, Luxembourg, pp. 143.

Garcia-Lozano, C., Pintó, J., Daunis-i-Estadella, P., 2018. Changes in coastal dune systems on the Catalan shoreline (Spain, NW Mediterranean Sea). Comparing dune landscapes between 1890 and 1960 with their current status. Estuarine, Coastal and Shelf Science. 208, 235-247. https://doi.org/10.1016/j.ecss.2018.05.004

Gigante, D., Acosta, A. T. R., Agrillo, E., Armiraglio, S., Assini, S., Attorre, F., Bagella, S., Bufa, G., Casella, L., Giancola, C., Giusso del Galdo, G.P., Marcenò, C., Pezzi, G., · Prisco, I., Venanzoni, R., Viciani, D., 2018. Habitat conservation in Italy: the state of the art in the light of the first European Red List of Terrestrial and Freshwater Habitats. Rendiconti Lincei. Scienze Fisiche e Naturali. 29, 251-265. https://doi.org/10.1007/s12210-018-0688-5

Gigante, D., Foggi, B., Venanzoni, R., Viciani, D., Buffa, G., 2016. Habitats on the grid: The spatial dimension does matter for red-listing. Journal for Nature Conservation.32, 1-9. https://doi.org/10.1016/j.jnc.2016.03.007

Heslenfeld, P., Jungerius, P.D., Klijn, J.A., 2004. European coastal dunes: ecological values, threats, opportunities and policy development. In: Martínez, M.L., Psuty, N.P., (eds) Costal dunes, ecology and conservation. Ecological studies, 171. Springer-Verlag, Berlin, pp. 335-351.

Higgins, J.P., Green, S. (Eds.)., 2011. Cochrane handbook for systematic reviews of interventions (Vol. 4). John Wiley \& Sons Ttd., Chichester, pp. 674. https://doi.org/10.1002/9780470712184 
Ichter, J., Evans, D., \& Richard, D., 2014. Terrestrial habitat mapping in Europe: an overview-European Environment Agency (EEA) (Publication). European Environment Agency (EU body or agency), Museum national d'Histoire naturelle (MNHN), Copenhague, pp. 153.

Jackson, D.W.T., Cooper, J.A.G., 2011. Coastal dune fields in Ireland: rapid regional response to climatic change. Journal of Coastal Research, 293-297.

Janssen, J.A.M., Rodwell, J.S., Criado, M.G., Arts, G.H.P., Bijlsma, R.J., Schaminee, J.H.J., 2016. European red list of habitats: Part 2. Terrestrial and freshwater habitats. European Union. Luxembourg, Luxembourg: Publications Office of the European Union, pp. 40.

Jiménez- Alfaro, B., Marcenò, C., Guarino, R., Chytrý, M., 2015. Regional metacommunities in two coastal systems: spatial structure and drivers of plant assemblages. Journal of Biogeography. 42, 452-462. https://doi.org/10.1111/jbi.12437 Ley de la Vega, C., Favennec, J., Gallego-Fernández J., et Pascual Vidal, C. (eds) (2012). Conservation des dunes côtières. Restauration et gestion durables en Méditerranée occidentale. UICN, Gland, Suisse et Malaga, Espagne, pp.124. Loidi, J., 1994. Phytosociology applied to nature conservation and land management, in: Song, Y., Dierschke, H. \& Wang, X. (eds.) Applied vegetation ecology. Proceedings of the 35th Symposium IAVS in Shanghai, East China Normal University Press, pp. 17-30.

Maciejewski, L., Lepareur, F., Viry, D., Bensettiti, F., Puissauve, R., Touroult, J., 2016. État de conservation des habitats : propositions de définitions et de concepts pour l'évaluation à l'échelle d'un site Natura 2000. Revue d'Écologie (Terre et Vie). 71, 3-20.

Mahdavi, P., Bergmeier, E., 2016. Plant functional traits and diversity in sand dune ecosystems across different biogeographic regions. Acta oecologica, 74, 37-45. https://doi.org/10.1016/j.actao.2016.06.003

Malavasi, M., Santoro, R., Cutini, M., Acosta, A.T.R., Carranza, M.L., 2013. What has happened to coastal dunes in the last half century? A multitemporal coastal landscape analysis in Central Italy. Landscape and Urban Planning. 119, 54-63. https://doi.org/10.1016/j.landurbplan.2013.06.012

McLachlan, A., \& Brown, A. C. (Eds.), 2006. The ecology of sandy shores. Academic Press, Burlington, MA, USA, pp. 373. https://doi.org/10.1016/B978-0-12-372569-1.X5000-9

Pakeman, R.J., Hewison, R.L., Lewis, R.J. 2017. Drivers of species richness and compositional change in Scottish coastal vegetation. Applied vegetation science. 20, 183-193. https://doi.org/10.1111/avsc.12283

Pettorelli, N., Owen, H.J.F., \& Duncan, C., 2016. How do we want Satellite Remote Sensing to support biodiversity conservation globally?. Methods in Ecology and Evolution, 7(6), 656-665. https://doi.org/10.1111/2041-210X.12545 Pinna, M.S., Cogoni, D., Fenu, G., Bacchetta, G., 2015. The conservation status and anthropogenic impacts assessments of Mediterranean coastal dunes. Estuarine, Coastal and Shelf Science. 167, 25-31. https://doi.org/10.1016/j.ecss.2015.07.002 Pott, R., 1997. Classification of European biotope-types for FFH-guidelines and the importance of phytosociology. Colloques Phytosociologiques. 27, 17-79

Prisco, I., Acosta, A.T.R., Ercole, S., 2012. An Overview of the Italian Coastal Dune Eu Habitats. Annali di Botanica. 2, 39 48. https://doi.org/10.4462/annbotrm-9340

Rodwell, J.S., Evans, D., Schaminée, J.H., 2018. Phytosociological relationships in European Union policy-related habitat classifications. Rendiconti Lincei. Scienze Fisiche e Naturali. 29, 237-249. https://doi.org/10.1007/s12210-018-0690-y R Core Team, 2014. R: A language and environment for statistical computing. R Foundation for Statistical Computing, Vienna, Austria. http://www.R-project.org/http://cran.r-project.org/

Šilc, U., Stešević, D., Rozman, A., Caković, D., Küzmič, F., 2019. Alien species and the impact on sand dunes along the NE adriatic coast, in: Makowski C, Finkl CW (eds) Impacts of invasive species on coastal environments. Springer, Cham, pp 113-143. https://doi.org/10.1007/978-3-319-91382-7_4

Simberloff, D., Martin, J. L., Genovesi, P., Maris, V., Wardle, D. A., Aronson, J., Courchamp, F., Galil, B., García-Berthou, E., Pascal, M., Pysek, P., Sousa, R., Tabacchi, E., Vila, M., 2013. Impacts of biological invasions: what's what and the way forward. Trends in ecology \& evolution. 28, 58-66. https://doi.org/10.1016/j.tree.2012.07.013

Sperandii, M.G., Bazzichetto, M., Gatti, F., Acosta, A.T.R., 2019. Back into the past: Resurveying random plots to track community changes in Italian coastal dunes. Ecological Indicators. 96, 572-578.

https://doi.org/10.1016/j.ecolind.2018.09.039

Sterr, H., 2008. Assessment of Vulnerability and Adaptation to Sea-Level Rise for the Coastal Zone of Germany. Journal of Coastal Research, 380-393. https://doi.org/10.2112/07A-0011.1

Tomaselli, V., Tenerelli, P., Sciandrello, S., 2012. Mapping and quantifying habitat fragmentation in small coastal areas: a case study of three protected wetlands in Apulia (Italy). Environmental monitoring and assessment. 184, 693-713. https://doi.org/10.1007/s10661-011-1995-9

Torca, M., Campos, J.A., Herrera, M., 2019. Changes in plant diversity patterns along dune zonation in south Atlantic European coasts. Estuarine, Coastal and Shelf Science. 218, 39-47. https://doi.org/10.1016/j.ecss.2018.11.016 Tsiripidis, I., Xystrakis, F., Kallimanis, A., Panitsa, M., Dimopoulos, P., 2018. A bottom-up approach for the conservation status assessment of structure and functions of habitat types. Rendiconti Lincei. Scienze Fisiche e Naturali. 29, $267-282$. https://doi.org/10.1007/s12210-018-0691-x

Tucker, G., Stuart, T., Naumann, S., Stein, U., Landgrebe-Trinkunaite, R., Knol, O., 2019. Study on identifying the drivers of successful implementation of the Birds and Habitats Directives. Report to the European Commission, DG Environment on Contract ENV.F.1/FRA/2014/0063, Institute for European Environmental Policy, Brussels, pp. 175.

Valentini, E., Taramelli, A., Filipponi, F., Giulio, S., 2015. An effective procedure for EUNIS and Natura 2000 habitat type mapping in estuarine ecosystems integrating ecological knowledge and remote sensing analysis. Ocean \& Coastal Management. 108, 52-64. https://doi.org/10.1016/j.ocecoaman.2014.07.015

Williams, A.T., Duck, R.W., Phillips, M.R., 2011. Coastal dune vulnerability among selected Scottish systems. Journal of Coastal Research. 1263-1267.

Zotero, 2020. Zotero. https://www.zotero.org/ (accessed 22 april 2019). 
632 Appendix A. Conservation status of coastal areas publications of ecological, interdisciplinary 633 and other foci included in our in-depth review (225 publications, period 1992-2019).

\begin{tabular}{|c|c|c|c|c|c|c|c|c|c|}
\hline Authors & Title & Item Type & Source Title & $\begin{array}{c}\text { Publication } \\
\text { Year }\end{array}$ & $\begin{array}{l}\text { Num } \\
\text { Pages }\end{array}$ & $\begin{array}{l}\text { Num } \\
\text { Pages }\end{array}$ & Issue & Volume & Language \\
\hline Loidi, J. & $\begin{array}{l}\text { Phytosociology applied to nature } \\
\text { conservation and land management }\end{array}$ & Journal - Article & $\begin{array}{c}\text { Applied } \\
\text { Vegetation } \\
\text { Ecology } \\
\end{array}$ & 1994 & $17-30$ & - & - & - & en \\
\hline $\begin{array}{l}\text { Van Wijnen, H. } \\
\text { J., Bakker, J. } \\
\text { P., De Vries, Y. }\end{array}$ & $\begin{array}{l}\text { Twenty years of salt marsh } \\
\text { succession on a Dutch coastal } \\
\text { barrier island }\end{array}$ & Journal - Article & $\begin{array}{l}\text { Journal of Coastal } \\
\text { Conservation }\end{array}$ & 1997 & $1-9$ & - & 1 & 3 & en \\
\hline $\begin{array}{l}\text { Acosta, A., } \\
\text { Blasi, C., \& } \\
\text { Stanisci, A. }\end{array}$ & $\begin{array}{l}\text { Spatial connectivity and boundary } \\
\text { patterns in coastal dune vegetation } \\
\text { in the Circeo National Park, } \\
\text { Central Italy }\end{array}$ & Journal - Article & $\begin{array}{l}\text { Journal of } \\
\text { Vegetation } \\
\text { Science }\end{array}$ & 2000 & $149-154$ & - & 1 & 11 & en \\
\hline $\begin{array}{l}\text { Esselink, P., } \\
\text { Zijlstra, W., } \\
\text { Dijkema, K. S., } \\
\text { van Diggelen, } \\
\text { R. } \\
\end{array}$ & $\begin{array}{l}\text { The effects of decreased } \\
\text { management on plant-species } \\
\text { distribution patterns in a salt marsh } \\
\text { nature reserve in the Wadden Sea }\end{array}$ & Journal - Article & $\begin{array}{l}\text { Biological } \\
\text { Conservation }\end{array}$ & 2000 & $61-76$ & - & 1 & 93 & en \\
\hline Lee, M. & $\begin{array}{l}\text { Coastal defence and the Habitats } \\
\text { Directive: predictions of habitat } \\
\text { change in England and Wales }\end{array}$ & Journal - Article & $\begin{array}{c}\text { The Geographical } \\
\text { Journal }\end{array}$ & 2001 & $39-56$ & - & 1 & 167 & en \\
\hline $\begin{array}{l}\text { Rodwell, J S, } \\
\text { Schaminée, J H } \\
\text { J, Mucina, L, } \\
\text { Pignatti, S, } \\
\text { Dring, J, Moss, } \\
\text { D }\end{array}$ & $\begin{array}{l}\text { The diversity of European } \\
\text { vegetation }\end{array}$ & Report & Report EC-LNV & 2002 & 116 & - & - & 54 & en \\
\hline $\begin{array}{l}\text { Ekebom, J., } \\
\text { Erkkilä, A. }\end{array}$ & $\begin{array}{l}\text { Using aerial photography for } \\
\text { identification of marine and coastal } \\
\text { habitats under the EU's Habitats } \\
\text { Directive: identifying marine and } \\
\text { coastal habitats from aerial } \\
\text { photographs }\end{array}$ & Journal - Article & $\begin{array}{l}\text { Aquatic } \\
\text { Conservation: } \\
\text { Marine and } \\
\text { Freshwater } \\
\text { Ecosystems }\end{array}$ & 2003 & $287-304$ & - & 4 & 13 & en \\
\hline Paskoff, R & $\begin{array}{l}\text { La conservation des dunes } \\
\text { littorales implique-t-elle leur } \\
\text { stabilisation? L'exemple de la côte } \\
\text { atlantiqueCoastal dune fields in } \\
\text { Atlantic Europe: towards a } \\
\text { dynamic conservation }\end{array}$ & Journal - Article & $\begin{array}{l}\text { Nature Sciences } \\
\text { Sociétés }\end{array}$ & 2003 & $288-294$ & - & 3 & 11 & fr \\
\hline $\begin{array}{l}\text { Bioret, F., } \\
\text { Glémarec, M., } \\
\text { Géhu, J.M. }\end{array}$ & $\begin{array}{l}\text { Identification des habitats côtiers } \\
\text { de la Directive Habitats présents en } \\
\text { France }\end{array}$ & Journal - Article & Fitosociologia & 2004 & $43-51$ & - & 1 & 41 & $\mathrm{fr}$ \\
\hline $\begin{array}{l}\text { Boteva, D., } \\
\text { Griffiths, G., } \\
\text { Dimopoulos, P. }\end{array}$ & $\begin{array}{l}\text { Evaluation and mapping of the } \\
\text { conservation significance of } \\
\text { habitats using GIS: an example } \\
\text { from Crete, Greece }\end{array}$ & Journal - Article & $\begin{array}{l}\text { Journal for Nature } \\
\text { Conservation }\end{array}$ & 2004 & $237-250$ & - & 4 & 12 & en \\
\hline $\begin{array}{l}\text { Ejrnæs, R., } \\
\text { Bruun, H. H., } \\
\text { Aude, E., } \\
\text { Buchwald, E. }\end{array}$ & $\begin{array}{l}\text { Developing a classifier for the } \\
\text { Habitats Directive grassland types } \\
\text { in Denmark using species lists for } \\
\text { prediction }\end{array}$ & Journal - Article & $\begin{array}{l}\text { Applied } \\
\text { Vegetation } \\
\text { Science }\end{array}$ & 2004 & $71-80$ & - & 1 & 7 & en \\
\hline $\begin{array}{l}\text { Schmidt, K.S., } \\
\text { Skidmore, } \\
\text { A.K., } \\
\text { Kloosterman, } \\
\text { E.H., van } \\
\text { Oosten, H., } \\
\text { Kumar, L., } \\
\text { Janssen, J.A.M. }\end{array}$ & $\begin{array}{l}\text { Mapping Coastal Vegetation Using } \\
\text { an Expert System and } \\
\text { Hyperspectral Imagery }\end{array}$ & Journal - Article & $\begin{array}{l}\text { Photogrammetric } \\
\text { Engineering \& } \\
\text { Remote Sensing }\end{array}$ & 2004 & $703-715$ & - & 6 & 70 & en \\
\hline $\begin{array}{l}\text { Stanisci, A., } \\
\text { Acosta, A., } \\
\text { Ercole, S., } \\
\text { Blasi, C. }\end{array}$ & $\begin{array}{l}\text { Plant communities on costal dunes } \\
\text { in Lazio (Italy) }\end{array}$ & Journal - Article & Annali di Botanica & 2004 & $115-128$ & - & - & 4 & en \\
\hline
\end{tabular}




\begin{tabular}{|c|c|c|c|c|c|c|c|c|c|}
\hline $\begin{array}{l}\text { Biondi, E., } \\
\text { Colosi, L. }\end{array}$ & $\begin{array}{l}\text { Environmental quality : An } \\
\text { assessment based on the characters } \\
\text { of the plant landscape. }\end{array}$ & Journal - Article & $\begin{array}{l}\text { Plant Biosystems - } \\
\text { An International } \\
\text { Journal Dealing } \\
\text { with all Aspects of } \\
\text { Plant Biology }\end{array}$ & 2005 & $145-154$ & - & 2 & 139 & en \\
\hline $\begin{array}{l}\text { Bock, M., } \\
\text { Rossner, G., } \\
\text { Wissen, M., } \\
\text { Remm, K., } \\
\text { Langanke, T., } \\
\text { Lang, S., Klug, } \\
\text { H., Blaschke, } \\
\text { T., Vrščaj, B. }\end{array}$ & $\begin{array}{l}\text { Spatial indicators for nature } \\
\text { conservation from European to } \\
\text { local scale }\end{array}$ & Journal - Article & $\begin{array}{l}\text { Ecological } \\
\text { Indicators }\end{array}$ & 2005 & $322-338$ & - & 4 & 5 & en \\
\hline $\begin{array}{l}\text { Dimopoulos, } \mathrm{P}, \\
\text { Bergmeier, E, } \\
\text { Fischer, P }\end{array}$ & $\begin{array}{l}\text { Monitoring and conservation } \\
\text { assessment of habtat types in } \\
\text { Greece: fundamentals and } \\
\text { exemplary cases }\end{array}$ & Journal - Article & Annali di Botanica & 2005 & $7-20$ & - & - & 5 & en \\
\hline $\begin{array}{l}\text { Penas, A., Del } \\
\text { Río, S., } \\
\text { Herrero, L. }\end{array}$ & $\begin{array}{l}\text { A new methodology for the } \\
\text { quantitative evaluation of the } \\
\text { conservation status of vegetation: } \\
\text { the potentiality distance index } \\
\text { (PDI). }\end{array}$ & Journal - Article & Fitosociologia & 2005 & $23-31$ & - & 2 & 42 & en \\
\hline $\begin{array}{l}\text { Acosta, A., } \\
\text { Ercole, S., } \\
\text { Stanisci, A., \& } \\
\text { Blasi, C. }\end{array}$ & $\begin{array}{l}\text { Sandy coastal ecosystems and } \\
\text { effects of disturbance in Central } \\
\text { Italy }\end{array}$ & Journal - Article & $\begin{array}{l}\text { Journal of Coastal } \\
\text { Research }\end{array}$ & 2006 & 985-989 & - & 39 & - & en \\
\hline $\begin{array}{l}\text { Alonso, I, } \\
\text { Sánchez, I, } \\
\text { Cabrera, L, } \\
\text { Benavides, A, } \\
\text { Alcántara- } \\
\text { Carrió, J, } \\
\text { Usera, J } \\
\end{array}$ & $\begin{array}{l}\text { Decadal Evolution of a Coastal } \\
\text { Dune Field and Adjacent Beaches } \\
\text { at North of Fuerteventura (Canary } \\
\text { Islands, Spain) }\end{array}$ & Journal - Article & $\begin{array}{l}\text { Journal of Coastal } \\
\text { Research }\end{array}$ & 2006 & $198-203$ & - & - & 39 & en \\
\hline $\begin{array}{l}\text { Arnaud- } \\
\text { Fassetta, G., } \\
\text { Bertrand, F., } \\
\text { Costa, S., } \\
\text { Davidson, R. }\end{array}$ & $\begin{array}{l}\text { The western lagoon marshes of the } \\
\text { Ria Formosa (Southern Portugal): } \\
\text { Sediment-vegetation dynamics, } \\
\text { long-term to short-term changes } \\
\text { and perspective }\end{array}$ & Journal - Article & $\begin{array}{l}\text { Continental Shelf } \\
\text { Research }\end{array}$ & 2006 & $363-384$ & - & 3 & 26 & en \\
\hline $\begin{array}{l}\text { Dimopoulos, } \\
\text { P., Bergmeier, } \\
\text { E., Fischer, P. }\end{array}$ & $\begin{array}{l}\text { Natura } 2000 \text { Habitat Types of } \\
\text { Greece Evaluated in the Light of } \\
\text { Distribution, threat and } \\
\text { Responsibility }\end{array}$ & Journal - Article & $\begin{array}{l}\text { Biology \& } \\
\text { Environment: } \\
\text { Proceedings of the } \\
\text { Royal Irish } \\
\text { Academy }\end{array}$ & 2006 & $175-187$ & - & 3 & 106 & en \\
\hline Evans, D. & $\begin{array}{l}\text { The Habitats of the European } \\
\text { Union Habitats Directive }\end{array}$ & Journal - Article & $\begin{array}{l}\text { Biology \& } \\
\text { Environment: } \\
\text { Proceedings of the } \\
\text { Royal Irish } \\
\text { Academy } \\
\end{array}$ & 2006 & $167-173$ & - & 3 & 106 & en \\
\hline $\begin{array}{l}\text { Frederiksen, L., } \\
\text { Kollmann, J., } \\
\text { Vestergaard, } \\
\text { P., Bruun, H.H. }\end{array}$ & $\begin{array}{l}\text { A multivariate approach to plant } \\
\text { community distribution in the } \\
\text { coastal dune zonation of NW } \\
\text { Denmark }\end{array}$ & Journal - Article & Phytocoenologia & 2006 & $321-342$ & - & 3 & 36 & en \\
\hline $\begin{array}{l}\text { Tagliapietra, } \\
\text { D., Ghirardini } \\
\text { Volpi, A. }\end{array}$ & $\begin{array}{l}\text { Notes on coastal lagoon typology } \\
\text { in the light of the EU Water } \\
\text { Framework Directive: Italy as a } \\
\text { case study }\end{array}$ & Journal - Article & $\begin{array}{c}\text { Aquatic } \\
\text { Conservation: } \\
\text { Marine and } \\
\text { Freshwater } \\
\text { Ecosystems }\end{array}$ & 2006 & $457-467$ & - & 5 & 16 & en \\
\hline $\begin{array}{l}\text { Acosta, A., } \\
\text { Ercole, S., } \\
\text { Stanisci, A., } \\
\text { Pillar, V. D. P., } \\
\text { \& Blasi, C. }\end{array}$ & $\begin{array}{l}\text { Coastal vegetation zonation and } \\
\text { dune morphology in some } \\
\text { Mediterranean ecosystems }\end{array}$ & Journal - Article & $\begin{array}{l}\text { Journal of Coastal } \\
\text { Research }\end{array}$ & 2007 & $\begin{array}{c}1518- \\
1524\end{array}$ & - & - & 236 & en \\
\hline $\begin{array}{l}\text { Costa, J.C., } \\
\text { Monteiro-- } \\
\text { Henriques, T., } \\
\text { Neto, C., } \\
\text { Arsénio, P., } \\
\text { Aguiar, C. } \\
\end{array}$ & $\begin{array}{l}\text { The application of the Habitats } \\
\text { Directive in Portugal }\end{array}$ & Journal - Article & Fitosociologia & 2007 & $23-28$ & - & - & 44 & en \\
\hline $\begin{array}{l}\text { Farris, E, } \\
\text { Pisanu, S, } \\
\text { Secchi, Z, } \\
\text { Bagella, S, }\end{array}$ & $\begin{array}{l}\text { Gli habitat terrestri costieri e } \\
\text { litorali della Sardegna } \\
\text { settentrionale: verifica della loro } \\
\text { attribuzione sintassonomica ai }\end{array}$ & Journal - Article & Fitosociologia & 2007 & $165-180$ & - & 1 & 44 & it \\
\hline
\end{tabular}




\begin{tabular}{|c|c|c|c|c|c|c|c|c|c|}
\hline $\begin{array}{l}\text { Urbani, M, } \\
\text { Filigheddu, R }\end{array}$ & $\begin{array}{l}\text { sensi della Direttiva 43/92/CEE } \\
\text { "Habitat" }\end{array}$ & & & & & & & & \\
\hline $\begin{array}{l}\text { Gardiner, S., } \\
\text { Hanson, S., } \\
\text { Nicholls, R., } \\
\text { Zhang, Z., } \\
\text { Jude, S., Jones, } \\
\text { A., Richards, } \\
\text { J., Williams, } \\
\text { A., Spencer, T., } \\
\text { Cope, S., } \\
\text { Gorczynska, } \\
\text { M., Bradbury, } \\
\text { A., McInnes, } \\
\text { R., Ingleby, A., } \\
\text { Dalton, H. }\end{array}$ & $\begin{array}{l}\text { The Habitats Directive, Coastal } \\
\text { Habitats and Climate Change - } \\
\text { Case Studies from the South Coast } \\
\text { of the UK }\end{array}$ & Journal - Article & $\begin{array}{l}\text { Southampton, } \\
\text { Tyndall Centre for } \\
\text { Climate Change } \\
\text { Research }\end{array}$ & 2007 & $1-17$ & - & - & - & en \\
\hline $\begin{array}{l}\text { Grunewald, R., } \\
\text { Schubert, H. }\end{array}$ & $\begin{array}{l}\text { The definition of a new plant } \\
\text { diversity index "H0 dune", for } \\
\text { assessing human damage on } \\
\text { coastal dunes-Derived from the } \\
\text { Shannon index of entropy H' }\end{array}$ & Journal - Article & $\begin{array}{l}\text { Ecological } \\
\text { indicators }\end{array}$ & 2007 & $1-21$ & - & 1 & 7 & en \\
\hline $\begin{array}{l}\text { Grunewald, R., } \\
\text { Schubert, H. }\end{array}$ & $\begin{array}{l}\text { The definition of a new plant } \\
\text { diversity index "H'dune" for } \\
\text { assessing human damage on } \\
\text { coastal dunes-Derived from the } \\
\text { Shannon index of entropy } \mathrm{H}^{\prime}\end{array}$ & Journal - Article & $\begin{array}{l}\text { Ecological } \\
\text { Indicators }\end{array}$ & 2007 & 44197 & - & 1 & 7 & en \\
\hline $\begin{array}{l}\text { Mehtälä, J., } \\
\text { Vuorisalo, T. }\end{array}$ & $\begin{array}{l}\text { Conservation policy and the EU } \\
\text { Habitats Directive: favourable } \\
\text { conservation status as a measure of } \\
\text { conservation success }\end{array}$ & Journal - Article & $\begin{array}{c}\text { European } \\
\text { Environment }\end{array}$ & 2007 & $363-375$ & - & 6 & 17 & en \\
\hline $\begin{array}{l}\text { Normand, S., } \\
\text { Svenning, J. C., } \\
\text { \& Skov, F. }\end{array}$ & $\begin{array}{l}\text { National and European } \\
\text { perspectives on climate change } \\
\text { sensitivity of the habitats directive } \\
\text { characteristic plant species }\end{array}$ & Journal - Article & $\begin{array}{l}\text { Journal for Nature } \\
\text { Conservation }\end{array}$ & 2007 & $41-53$ & - & 1 & 15 & en \\
\hline $\begin{array}{l}\text { Rodwell, J S, } \\
\text { Morgan, V, } \\
\text { Jefferson, R G, } \\
\text { Moss, D }\end{array}$ & $\begin{array}{l}\text { The Habitats Directive in the UK: } \\
\text { some wider questions raised by the } \\
\text { definition, notification and } \\
\text { monitoring of grassland habitats }\end{array}$ & Journal - Article & Fitosociologia & 2007 & $37-47$ & - & 2 & 44 & en \\
\hline $\begin{array}{l}\text { Acosta, A., } \\
\text { Carranza, M. } \\
\text { L., \& Izzi, C. F. }\end{array}$ & $\begin{array}{l}\text { Community types and alien species } \\
\text { distribution in Italian coastal dunes }\end{array}$ & Journal - Article & $\begin{array}{c}\text { Biological } \\
\text { Invasions: From } \\
\text { Ecology to } \\
\text { Conservation } \\
\end{array}$ & 2008 & 96-104 & - & - & - & en \\
\hline $\begin{array}{l}\text { Acosta, A., } \\
\text { Carranza, M. } \\
\text { L., Di Martino, } \\
\text { L., Frattaroli, } \\
\text { A., Izzi, C. F., } \\
\text { \& Stanisci, A. }\end{array}$ & $\begin{array}{l}\text { Patterns of native and alien plant } \\
\text { species occurrence on coastal } \\
\text { dunes in Central Italy }\end{array}$ & Journal - Article & Plant Invasions & 2008 & $235-248$ & & - & - & en \\
\hline $\begin{array}{l}\text { Carranza, M.L., } \\
\text { Acosta, A.T.R., } \\
\text { Stanisci, A., } \\
\text { Pirone, G., } \\
\text { Ciaschetti, G. }\end{array}$ & $\begin{array}{l}\text { Ecosystem classification for EU } \\
\text { habitat distribution assessment in } \\
\text { sandy coastal environments: An } \\
\text { application in central Italy }\end{array}$ & Journal - Article & $\begin{array}{l}\text { Environmental } \\
\text { Monitoring and } \\
\text { Assessment }\end{array}$ & 2008 & $99-107$ & - & $1-3$ & 140 & en \\
\hline $\begin{array}{l}\text { Carreño, M.F., } \\
\text { Esteve, M.A., } \\
\text { Martinez, J., } \\
\text { Palazón, J.A., } \\
\text { Pardo, M.T. } \\
\end{array}$ & $\begin{array}{l}\text { Habitat changes in coastal } \\
\text { wetlands associated to hydrological } \\
\text { changes in the watershed }\end{array}$ & Journal - Article & $\begin{array}{l}\text { Estuarine, Coastal } \\
\text { and Shelf Science }\end{array}$ & 2008 & $475-483$ & - & 3 & 77 & en \\
\hline
\end{tabular}




\begin{tabular}{|c|c|c|c|c|c|c|c|c|c|}
\hline $\begin{array}{l}\text { Chust, G., } \\
\text { Galparsoro, I., } \\
\text { Borja, Á., } \\
\text { Franco, J., } \\
\text { Uriarte, A. }\end{array}$ & $\begin{array}{l}\text { Coastal and estuarine habitat } \\
\text { mapping, using LIDAR height and } \\
\text { intensity and multi-spectral } \\
\text { imagery }\end{array}$ & Journal - Article & $\begin{array}{l}\text { Estuarine, Coastal } \\
\text { and Shelf Science }\end{array}$ & 2008 & $633-643$ & - & 4 & 78 & en \\
\hline $\begin{array}{l}\text { Hardegen, M., } \\
\text { Bougault, C., } \\
\text { Quéré, E. }\end{array}$ & $\begin{array}{l}\text { La cartographie des habitats dans } \\
\text { les sites Natura } 2000 \text { de Bretagne. } \\
\text { Application aux landes littorales de } \\
\text { l'île de Groix et de la presqu'île de } \\
\text { Crozon }\end{array}$ & Journal - Article & $\begin{array}{l}\text { Acta Botanica } \\
\text { Gallica }\end{array}$ & 2008 & $153-159$ & - & 1 & 155 & $\mathrm{fr}$ \\
\hline $\begin{array}{l}\text { Hardegen, M., } \\
\text { Bougault, C., } \\
\text { Quéré, E. }\end{array}$ & $\begin{array}{l}\text { La cartographie des habitats dans } \\
\text { les sites Natura } 2000 \text { de Bretagne. } \\
\text { Application aux landes littorales de } \\
\text { l'île de Groix et de la presqu'île de } \\
\text { Crozon }\end{array}$ & Journal - Article & $\begin{array}{l}\text { Acta Botanica } \\
\text { Gallica }\end{array}$ & 2008 & $153-159$ & - & 1 & 155 & $\mathrm{fr}$ \\
\hline $\begin{array}{l}\text { Lengyel, S., } \\
\text { Déri, E., Varga, } \\
\text { Z., Horváth, R., } \\
\text { Tóthmérész, } \\
\text { B., Henry, P.- } \\
\text { Y., Kobler, A., } \\
\text { Kutnar, L., } \\
\text { Babij, V., } \\
\text { Seliskar, A., } \\
\text { Christia, C., } \\
\text { Papastergiadou, } \\
\text { E., Gruber, B., } \\
\text { Henle, K., }\end{array}$ & $\begin{array}{l}\text { Habitat monitoring in Europe: a } \\
\text { description of current practices }\end{array}$ & Journal - Article & $\begin{array}{l}\text { Biodiversity and } \\
\text { Conservation }\end{array}$ & 2008 & $\begin{array}{l}3327- \\
3339\end{array}$ & - & 14 & 17 & en \\
\hline $\begin{array}{l}\text { Lengyel, S., } \\
\text { Kobler, A., } \\
\text { Kutnar, L., } \\
\text { Framstad, E., } \\
\text { Henry, P.-Y., } \\
\text { Babij, V., } \\
\text { Gruber, B., } \\
\text { Schmeller, D. } \\
\text { S., Henle, K. }\end{array}$ & $\begin{array}{l}\text { A review and a framework for the } \\
\text { integration of biodiversity } \\
\text { monitoring at the habitat level }\end{array}$ & Journal - Article & $\begin{array}{l}\text { Biodiversity and } \\
\text { Conservation }\end{array}$ & 2008 & $\begin{array}{l}3341- \\
3356\end{array}$ & - & 14 & 17 & en \\
\hline $\begin{array}{l}\text { Stancic, Z., } \\
\text { Brigic, A., } \\
\text { Liber, Z., } \\
\text { Rusak, G., } \\
\text { Franjic, J., } \\
\text { Skvorc, Z. }\end{array}$ & $\begin{array}{l}\text { Adriatic coastal plant taxa and } \\
\text { communities of Croatia and their } \\
\text { threat status }\end{array}$ & Journal - Article & $\begin{array}{l}\text { Acta Botanica } \\
\text { Gallica }\end{array}$ & 2008 & 179-199 & - & 2 & 155 & en \\
\hline Sterr, H. & $\begin{array}{l}\text { Assessment of Vulnerability and } \\
\text { Adaptation to Sea-Level Rise for } \\
\text { the Coastal Zone of Germany }\end{array}$ & Journal - Article & $\begin{array}{l}\text { Journal of Coastal } \\
\text { Research }\end{array}$ & 2008 & $380-393$ & - & - & - & en \\
\hline $\begin{array}{l}\text { Carboni, M., } \\
\text { Carranza, M.- } \\
\text { L., Acosta, A. }\end{array}$ & $\begin{array}{l}\text { Assessing conservation status on } \\
\text { coastal dunes: A multiscale } \\
\text { approach }\end{array}$ & Journal - Article & $\begin{array}{l}\text { Landscape and } \\
\text { Urban Planning }\end{array}$ & 2009 & $17-25$ & - & 1 & 91 & en \\
\hline $\begin{array}{l}\text { Gallet, S., } \\
\text { Bioret, F., } \\
\text { Hélou, A. }\end{array}$ & $\begin{array}{l}\text { Quelles méthodes pour le suivi et } \\
\text { l'évaluation des opérations de } \\
\text { restauration écologique? Exemple } \\
\text { de la Côte Sauvage de Quiberon }\end{array}$ & Journal - Article & $\begin{array}{l}\text { Ingénieries eau- } \\
\text { agriculture- } \\
\text { territoires }\end{array}$ & 2009 & $73-81$ & - & - & - & $\mathrm{fr}$ \\
\hline $\begin{array}{l}\text { Grande, M, } \\
\text { Chust, G, } \\
\text { Fernandes, J A, } \\
\text { Galparsoro, I }\end{array}$ & $\begin{array}{l}\text { Assessment of the discrimination } \\
\text { potential of bathymetric LIDAR } \\
\text { and multispectral imagery for } \\
\text { intertidal and subtidal habitats }\end{array}$ & Journal - Article & $\begin{array}{l}\text { European Master } \\
\text { of Science in } \\
\text { Marine } \\
\text { Enviroment and } \\
\text { Resources }\end{array}$ & 2009 & - & 5 & - & - & en \\
\hline $\begin{array}{l}\text { Kontula, T., } \\
\text { Raunio, A. }\end{array}$ & $\begin{array}{l}\text { New method and criteria for } \\
\text { national assessments of threatened } \\
\text { habitat types }\end{array}$ & Journal - Article & $\begin{array}{l}\text { Biodiversity and } \\
\text { Conservation }\end{array}$ & 2009 & $\begin{array}{c}3861- \\
3876\end{array}$ & - & 14 & 18 & en \\
\hline $\begin{array}{l}\text { Mücher, C.A., } \\
\text { Hennekens, } \\
\text { S.M., Bunce, } \\
\text {.G.H., } \\
\text { Schaminée, } \\
\text { J.H.J., } \\
\text { Schaepman, } \\
\text { M.E. }\end{array}$ & $\begin{array}{l}\text { Modelling the spatial distribution } \\
\text { of Natura } 2000 \text { habitats across } \\
\text { Europe }\end{array}$ & Journal - Article & $\begin{array}{l}\text { Landscape and } \\
\text { Urban Planning }\end{array}$ & 2009 & $148-159$ & - & 2 & 92 & en \\
\hline
\end{tabular}




\begin{tabular}{|c|c|c|c|c|c|c|c|c|c|}
\hline $\begin{array}{l}\text { Carranza, M.- } \\
\text { L., Carboni, } \\
\text { M., Feola, S., } \\
\text { Acosta, A. }\end{array}$ & $\begin{array}{l}\text { Landscape-scale patterns of alien } \\
\text { plant species on coastal dunes: the } \\
\text { case of iceplant in central Italy }\end{array}$ & Journal - Article & $\begin{array}{l}\text { Applied } \\
\text { Vegetation } \\
\text { Science }\end{array}$ & 2010 & $135-145$ & - & 2 & 13 & en \\
\hline $\begin{array}{l}\text { Cutini, M., } \\
\text { Agostinelli, E., } \\
\text { Acosta, T.R.A., } \\
\text { Molina, J.A. }\end{array}$ & $\begin{array}{l}\text { Coastal salt- marsh zonation in } \\
\text { Tyrrhenian central Italy and its } \\
\text { relationship with other } \\
\text { Mediterranean wetlands }\end{array}$ & Journal - Article & $\begin{array}{l}\text { Plant Biosystems - } \\
\text { An International } \\
\text { Journal Dealing } \\
\text { with all Aspects of } \\
\text { Plant Biology }\end{array}$ & 2010 & 43770 & - & 1 & 144 & en \\
\hline $\begin{array}{l}\text { Gutierres, F., } \\
\text { Portela-Pereira, } \\
\text { E., Martins, M., } \\
\text { Neto, C., } \\
\text { Costa, J. C. }\end{array}$ & $\begin{array}{l}\text { Cartografia e Interpretação de } \\
\text { Habitats (Rede Natura 2000). Dois } \\
\text { Exemplos no Portugal } \\
\text { Mediterrânico }\end{array}$ & Journal - Article & \begin{tabular}{|l|} 
Actas do XII \\
Colóquio Ibérico \\
de Geografia. \\
Porto: Faculdade \\
de Letras \\
(Universidade do \\
Porto). \\
\end{tabular} & 2010 & $1-24$ & - & - & - & po \\
\hline $\begin{array}{l}\text { Isermann, M., } \\
\text { Koehler, H., } \\
\text { Mühl, M. }\end{array}$ & $\begin{array}{l}\text { Interactive effects of rabbit grazing } \\
\text { and environmental factors on plant } \\
\text { species-richness on dunes of } \\
\text { Norderney }\end{array}$ & Journal - Article & $\begin{array}{l}\text { Journal of Coastal } \\
\text { Conservation }\end{array}$ & 2010 & $103-114$ & - & 2 & 14 & en \\
\hline $\begin{array}{l}\text { Mclaughlin, } \\
\text { Suzanne, } \\
\text { Cooper, J. } \\
\text { Andrew G. }\end{array}$ & $\begin{array}{l}\text { A multi-scale coastal vulnerability } \\
\text { index: A tool for coastal managers? }\end{array}$ & Journal - Article & $\begin{array}{l}\text { Environmental } \\
\text { Hazards }\end{array}$ & 2010 & $233-248$ & - & 3 & 9 & en \\
\hline $\begin{array}{l}\text { Plus, M., } \\
\text { Dalloyau, S., } \\
\text { Trut, G., Auby, } \\
\text { A., de } \\
\text { Montaudouin, } \\
\text { X., Eric, E., } \\
\text { Noël, C., Viala, } \\
\text { C. }\end{array}$ & $\begin{array}{l}\text { Long-term evolution (1988-2008) } \\
\text { of Zostera spp. meadows in } \\
\text { Arcachon Bay (Bay of Biscay) }\end{array}$ & Journal - Article & $\begin{array}{l}\text { Estuarine, Coastal } \\
\text { and Shelf Science }\end{array}$ & 2010 & $357-366$ & - & 2 & 87 & en \\
\hline $\begin{array}{l}\text { Sipkova, Z., } \\
\text { Balzer, S., } \\
\text { Evans, D., } \\
\text { Ssymank, A. }\end{array}$ & $\begin{array}{l}\text { Assessing the conservation status } \\
\text { of European Union habitats-results } \\
\text { of the Community Report with a } \\
\text { case study of the German National } \\
\text { Report. }\end{array}$ & Journal - Article & Annali di Botanica & 2010 & $1-19$ & - & - & - & en \\
\hline $\begin{array}{l}\text { Bioret, F., } \\
\text { Lazare, J.-J. \& } \\
\text { Géhu J.-M. }\end{array}$ & $\begin{array}{l}\text { Évaluation patrimoniale et } \\
\text { vulnérabilité des associations } \\
\text { végétales du littoral atlantique } \\
\text { français }\end{array}$ & Journal - Article & $\begin{array}{c}\text { Journal de } \\
\text { Botanique de la } \\
\text { Société } \\
\text { Botanique de } \\
\text { France }\end{array}$ & 2011 & $39-67$. & - & - & 56 & $\mathrm{fr}$ \\
\hline $\begin{array}{l}\text { De Luca, E., } \\
\text { Novelli, C., } \\
\text { Barbato, F., } \\
\text { Menegoni, P., } \\
\text { Iannetta, M., } \\
\text { Nascetti, G. }\end{array}$ & $\begin{array}{l}\text { Coastal dune systems and } \\
\text { disturbance factors: monitoring and } \\
\text { analysis in central Italy }\end{array}$ & Journal - Article & $\begin{array}{c}\text { Environmental } \\
\text { Monitoring and } \\
\text { Assessment }\end{array}$ & 2011 & $437-450$ & - & $1-4$ & 183 & en \\
\hline $\begin{array}{l}\text { Donat, M.P., } \\
\text { Martínez Fort, } \\
\text { J. }\end{array}$ & $\begin{array}{l}\text { Evaluación de la vegetación en un } \\
\text { área del litoral mediterráneo en } \\
\text { Alicante (España). }\end{array}$ & Journal - Article & Fitosociologia & 2011 & $55-66$ & - & 2 & 48 & es \\
\hline $\begin{array}{l}\text { Evans, D., \& } \\
\text { Arvela, M. }\end{array}$ & $\begin{array}{l}\text { Assessment and reporting under } \\
\text { Article } 17 \text { of the Habitats } \\
\text { Directive. Explanatory Notes \& } \\
\text { Guidelines for the period 2007- } \\
2012 \\
\end{array}$ & Report & $\begin{array}{l}\text { European } \\
\text { Commission, } \\
\text { Brussels }\end{array}$ & 2011 & 121 & - & - & - & en \\
\hline $\begin{array}{l}\text { Feola, S., } \\
\text { Carranza, M. } \\
\text { L., Schaminée, } \\
\text { J. H. J., } \\
\text { Janssen, J. A. } \\
\text { M., Acosta, A. } \\
\text { T. R. }\end{array}$ & $\begin{array}{l}\text { EU habitats of interest: an insight } \\
\text { into Atlantic and Mediterranean } \\
\text { beach and foredunes }\end{array}$ & Journal - Article & $\begin{array}{l}\text { Biodiversity and } \\
\text { Conservation }\end{array}$ & 2011 & $\begin{array}{l}1457- \\
1468\end{array}$ & - & 7 & 20 & en \\
\hline
\end{tabular}




\begin{tabular}{|c|c|c|c|c|c|c|c|c|c|}
\hline $\begin{array}{l}\text { Galdenzi, D, } \\
\text { Pesaresi, S, } \\
\text { Colosi, L, } \\
\text { Biondi, E }\end{array}$ & $\begin{array}{l}\text { Methodological aspects for the } \\
\text { evaluation of the quality of agro- } \\
\text { ecosystems and landscapes that } \\
\text { give rise. }\end{array}$ & Journal - Article & Fitosociologia & 2011 & $65-76$ & - & 2 & 48 & en \\
\hline $\begin{array}{l}\text { Goberville, E., } \\
\text { Beaugrand, G., } \\
\text { Sautour, B., \& } \\
\text { Tréguer, P. }\end{array}$ & $\begin{array}{l}\text { Evaluation of coastal perturbations: } \\
\text { A new mathematical procedure to } \\
\text { detect changes in the reference } \\
\text { state of coastal systems }\end{array}$ & Journal - Article & $\begin{array}{l}\text { Ecological } \\
\text { Indicators }\end{array}$ & 2011 & $\begin{array}{c}1290- \\
1300\end{array}$ & - & 5 & 11 & en \\
\hline Goffé, L. & $\begin{array}{l}\text { Etat de conservation des habitats } \\
\text { d'intérêt communautaire des dunes } \\
\text { non boisées du littoral atlantique- } \\
\text { Méthode d'évaluation à l'échelle } \\
\text { du site Natura 2000- }\end{array}$ & Report & SPN Rapport & 2011 & 83 & - & - & 18 & fr \\
\hline $\begin{array}{l}\text { Jackson, } \\
\text { D.W.T., } \\
\text { Cooper, J.A.G. }\end{array}$ & $\begin{array}{l}\text { Coastal dune fields in Ireland: } \\
\text { rapid regional response to climatic } \\
\text { change }\end{array}$ & Journal - Article & $\begin{array}{l}\text { Journal of Coastal } \\
\text { Research }\end{array}$ & 2011 & 293-297 & - & - & - & en \\
\hline $\begin{array}{l}\text { Jansen, F., } \\
\text { Ewald, J., } \\
\text { Zerbe, S. }\end{array}$ & $\begin{array}{l}\text { Ecological preferences of alien } \\
\text { plant species in North-Eastern } \\
\text { Germany }\end{array}$ & Journal - Article & $\begin{array}{l}\text { Biological } \\
\text { Invasions }\end{array}$ & 2011 & $\begin{array}{l}2691- \\
2701\end{array}$ & - & 12 & 13 & en \\
\hline $\begin{array}{l}\text { Louette, G., } \\
\text { Adriaens, D., } \\
\text { Adriaens, P., } \\
\text { Anselin, A., } \\
\text { Devos, K., } \\
\text { Sannen, K., } \\
\text { Van Landuyt, } \\
\text { W., Paelinckx, } \\
\text { D., Hoffmann, } \\
\text { M. } \\
\end{array}$ & $\begin{array}{l}\text { Bridging the gap between the } \\
\text { Natura } 2000 \text { regional conservation } \\
\text { status and local conservation } \\
\text { objectives }\end{array}$ & Journal - Article & $\begin{array}{c}\text { Journal for Nature } \\
\text { Conservation }\end{array}$ & 2011 & $224-235$ & - & 4 & 19 & en \\
\hline $\begin{array}{l}\text { Miccadei, E., } \\
\text { Mascioli, F., } \\
\text { Piacentini, T., } \\
\text { Ricci, F. }\end{array}$ & $\begin{array}{l}\text { Geomorphological Features of } \\
\text { Coastal Dunes along the Central } \\
\text { Adriatic Coast (Abruzzo, Italy) }\end{array}$ & Journal - Article & $\begin{array}{l}\text { Journal of Coastal } \\
\text { Research }\end{array}$ & 2011 & $\begin{array}{c}1122- \\
1136\end{array}$ & - & 6 & 27 & en \\
\hline $\begin{array}{l}\text { Nielsen, K. E., } \\
\text { Degn, H. J., } \\
\text { Damgaard, C., } \\
\text { Bruus, M., \& } \\
\text { Nygaard, B. }\end{array}$ & $\begin{array}{l}\text { A Native Species with Invasive } \\
\text { Behaviour in Coastal Dunes: } \\
\text { Evidence for Progressing Decay } \\
\text { and Homogenization of Habitat } \\
\text { Types }\end{array}$ & Journal - Article & AMBIO & 2011 & $819-823$ & - & 7 & 40 & en \\
\hline $\begin{array}{l}\text { Panitsa, M., } \\
\text { Koutsias, N., } \\
\text { Tsiripidis, I., } \\
\text { Zotos, A., } \\
\text { Dimopoulos, P. }\end{array}$ & $\begin{array}{l}\text { Species-based versus habitat-based } \\
\text { evaluation for conservation status } \\
\text { assessment of habitat types in the } \\
\text { East Aegean islands (Greece) }\end{array}$ & Journal - Article & $\begin{array}{l}\text { Journal for Nature } \\
\text { Conservation }\end{array}$ & 2011 & $269-275$ & - & 5 & 19 & en \\
\hline $\begin{array}{l}\text { Provoost, S., } \\
\text { Jones, M. } \\
\text { Laurence M., } \\
\text { Edmondson, } \\
\text { S.E. }\end{array}$ & $\begin{array}{l}\text { Changes in landscape and } \\
\text { vegetation of coastal dunes in } \\
\text { northwest Europe: a review }\end{array}$ & Journal - Article & $\begin{array}{c}\text { Journal of Coastal } \\
\text { Conservation }\end{array}$ & 2011 & $207-226$ & - & 1 & 15 & en \\
\hline $\begin{array}{l}\text { Tortajada, S., } \\
\text { Niquil, N., } \\
\text { Blanchet, H., } \\
\text { Grami, B., } \\
\text { Montanié, H., } \\
\text { David, V., Glé, } \\
\text { C., Saint-Béat, } \\
\text { B., Johnson, } \\
\text { G.A., Marquis, } \\
\text { E., Del Amo, } \\
\text { Y., Dubois, S., } \\
\text { Vincent, D., } \\
\text { Dupuy, C., } \\
\text { Jude, F., } \\
\text { Hartmann, H.J., } \\
\text { Sautour, B. }\end{array}$ & $\begin{array}{l}\text { Variability of fresh- and salt-water } \\
\text { marshes characteristics on the west } \\
\text { coast of France: A spatio-temporal } \\
\text { assessment }\end{array}$ & Journal - Article & Water Research & 2011 & $\begin{array}{l}4152- \\
4168\end{array}$ & - & 14 & 45 & en \\
\hline
\end{tabular}




\begin{tabular}{|c|c|c|c|c|c|c|c|c|c|}
\hline $\begin{array}{l}\text { Williams, A T, } \\
\text { Duck, R W, } \\
\text { Phillips, M R }\end{array}$ & $\begin{array}{l}\text { Coastal dune vulnerability among } \\
\text { selected Scottish systems }\end{array}$ & Journal - Article & $\begin{array}{l}\text { Journal of Coastal } \\
\text { Research }\end{array}$ & 2011 & $\begin{array}{l}1263- \\
1267\end{array}$ & - & 57 & - & en \\
\hline $\begin{array}{l}\text { Baumberger, } \\
\text { T., Affre, L., } \\
\text { Torre, F., } \\
\text { Vidal, E., } \\
\text { Dumas, P.-J., } \\
\text { Tatoni, T. }\end{array}$ & $\begin{array}{l}\text { Plant community changes as } \\
\text { ecological indicator of seabird } \\
\text { colonies' impacts on } \\
\text { Mediterranean Islands }\end{array}$ & Journal - Article & $\begin{array}{l}\text { Ecological } \\
\text { Indicators }\end{array}$ & 2012 & $76-84$ & - & 1 & 15 & en \\
\hline $\begin{array}{l}\text { Biondi, E., } \\
\text { Burrascano, S., } \\
\text { Casavecchia, } \\
\text { S., Copiz, R., } \\
\text { Del Vico, E., } \\
\text { Galdenzi, D., } \\
\text { Gigante, D., } \\
\text { Lasen, C., } \\
\text { Spampinato, } \\
\text { G., Venanzoni, } \\
\text { R., Zivkovic, } \\
\text { L., Blasi, C. }\end{array}$ & $\begin{array}{l}\text { Diagnosis and syntaxonomic } \\
\text { interpretation of Annex I Habitats } \\
\text { (Dir. 92/43/EEC) in Italy at the } \\
\text { alliance level }\end{array}$ & Journal - Article & Plant sociology & 2012 & $5-37$ & - & 1 & 49 & en \\
\hline $\begin{array}{l}\text { Buffa, } \\
\text { Gabriella, } \\
\text { Fantinato, Edy, } \\
\text { Pizzo, } \\
\text { Leonardo }\end{array}$ & $\begin{array}{l}\text { Effects of Disturbance on Sandy } \\
\text { Coastal Ecosystems of N-Adriatic } \\
\text { Coasts (Italy) }\end{array}$ & bookSection & $\begin{array}{l}\text { Biodiversity } \\
\text { Enrichment in a } \\
\text { Diverse World }\end{array}$ & 2012 & $339-372$ & - & - & - & en \\
\hline $\begin{array}{l}\text { de la Vega, L. } \\
\text { C., Favennec, } \\
\text { J., Gallego- } \\
\text { Fernández J., } \\
\text { Pascual Vidal, } \\
\text { C.(eds) }\end{array}$ & $\begin{array}{l}\text { Conservation des dunes côtières } \\
\text { Restauration et gestion durables en } \\
\text { Méditerranée occidentale }\end{array}$ & Report & $\begin{array}{l}\text { Union } \\
\text { Internationale pour } \\
\text { la Conservation de } \\
\text { la Nature et de ses } \\
\text { ressources }\end{array}$ & 2012 & - & 124 & - & - & $\mathrm{fr}$ \\
\hline $\begin{array}{l}\text { Debaine, F., } \\
\text { Robin, M. }\end{array}$ & $\begin{array}{l}\text { A new GIS modelling of coastal } \\
\text { dune protection services against } \\
\text { physical coastal hazards }\end{array}$ & Journal - Article & $\begin{array}{l}\text { Ocean \& Coastal } \\
\text { Management }\end{array}$ & 2012 & $43-54$ & - & - & 63 & en \\
\hline $\begin{array}{l}\text { Fenu, G., } \\
\text { Cogoni, D., } \\
\text { Ferrara, C., } \\
\text { Pinna, M. S., } \\
\text { Bacchetta, G. }\end{array}$ & $\begin{array}{l}\text { Relationships between coastal sand } \\
\text { dune properties and plant } \\
\text { community distribution: The case } \\
\text { of Is Arenas (Sardinia) }\end{array}$ & Journal - Article & $\begin{array}{l}\text { Plant Biosystems - } \\
\text { An International } \\
\text { Journal Dealing } \\
\text { with all Aspects of } \\
\text { Plant Biology }\end{array}$ & 2012 & $586-602$ & - & 3 & 146 & en \\
\hline $\begin{array}{l}\text { Gamito, S., } \\
\text { Patrício, J., } \\
\text { Neto, J. M., } \\
\text { Marques, J. C., } \\
\text { Teixeira, H. }\end{array}$ & $\begin{array}{l}\text { The importance of habitat-type for } \\
\text { defining the reference conditions } \\
\text { and the ecological quality status } \\
\text { based on benthic invertebrates: The } \\
\text { Ria Formosa coastal lagoon } \\
\text { (Southern Portugal) case study }\end{array}$ & Journal - Article & $\begin{array}{l}\text { Ecological } \\
\text { Indicators }\end{array}$ & 2012 & $61-72$ & - & - & 19 & en \\
\hline $\begin{array}{l}\text { Prisco, I. } \\
\text { Carboni, M., } \\
\text { Teresa, A.T.R } \\
\end{array}$ & $\begin{array}{l}\text { VegDunes - a coastal dune } \\
\text { vegetation database for the analysis } \\
\text { of Italian EU habitats }\end{array}$ & Journal - Article & $\begin{array}{l}\text { Biodiversity \& } \\
\text { Ecology }\end{array}$ & 2012 & $191-200$ & - & - & 4 & en \\
\hline $\begin{array}{l}\text { Prisco, I., } \\
\text { Acosta, A. T. } \\
\text { R., Ercole, S. }\end{array}$ & $\begin{array}{l}\text { An Overview of the Italian Coastal } \\
\text { Dune Eu Habitats }\end{array}$ & Journal - Article & Annali di Botanica & 2012 & $39-48$ & - & - & 2 & en \\
\hline $\begin{array}{l}\text { Sancho, F.E., } \\
\text { Freire, P., \& }\end{array}$ & $\begin{array}{l}\text { Coastal dunes vulnerability } \\
\text { indexes: a new proposal and }\end{array}$ & Journal - Article & $\begin{array}{c}\text { Coastal } \\
\text { engineering }\end{array}$ & 2012 & 12 & - & - & - & en \\
\hline
\end{tabular}




\begin{tabular}{|c|c|c|c|c|c|c|c|c|c|}
\hline $\begin{array}{l}\text { Oliveira, } \\
\text { F.S.B.F. }\end{array}$ & $\begin{array}{l}\text { aplication to Ria Formosa coast } \\
\text { (Portugal). }\end{array}$ & & & & & & & & \\
\hline $\begin{array}{l}\text { Schmeller, D., } \\
\text { Maier, A., } \\
\text { Evans, D., } \\
\text { Henle, K. }\end{array}$ & $\begin{array}{l}\text { National responsibilities for } \\
\text { conserving habitats - a freely } \\
\text { scalable method }\end{array}$ & Journal - Article & $\begin{array}{c}\text { Nature } \\
\text { Conservation }\end{array}$ & 2012 & $21-44$ & - & - & 3 & en \\
\hline $\begin{array}{l}\text { Tomaselli, V., } \\
\text { Tenerelli, P., } \\
\text { Sciandrello, S. }\end{array}$ & $\begin{array}{l}\text { Mapping and quantifying habitat } \\
\text { fragmentation in small coastal } \\
\text { areas: a case study of three } \\
\text { protected wetlands in Apulia } \\
\text { (Italy) }\end{array}$ & Journal - Article & $\begin{array}{l}\text { Environmental } \\
\text { Monitoring and } \\
\text { Assessment }\end{array}$ & 2012 & $693-713$ & - & 2 & 184 & en \\
\hline $\begin{array}{l}\text { Angiolini, C., } \\
\text { Landi, M., } \\
\text { Pieroni, G., } \\
\text { Frignani, F., } \\
\text { Finoia, M.-G., } \\
\text { Gaggi, C. }\end{array}$ & $\begin{array}{l}\text { Soil chemical features as key } \\
\text { predictors of plant community } \\
\text { occurrence in a Mediterranean } \\
\text { coastal ecosystem }\end{array}$ & Journal - Article & $\begin{array}{l}\text { Estuarine, Coastal } \\
\text { and Shelf Science }\end{array}$ & 2013 & $91-100$ & - & - & 119 & en \\
\hline $\begin{array}{l}\text { Attorre, F., } \\
\text { Maggini, A., Di } \\
\text { Traglia, M., De } \\
\text { Sanctis, M., } \\
\text { Vitale, M. }\end{array}$ & $\begin{array}{l}\text { A methodological approach for } \\
\text { assessing the effects of disturbance } \\
\text { factors on the conservation status } \\
\text { of Mediterranean coastal dune } \\
\text { systems }\end{array}$ & Journal - Article & $\begin{array}{l}\text { Applied } \\
\text { Vegetation } \\
\text { Science }\end{array}$ & 2013 & $333-342$ & - & 2 & 16 & en \\
\hline $\begin{array}{l}\text { Bessa, F., } \\
\text { Cunha, D., } \\
\text { Gonçalves, } \\
\text { S.C., Marques, } \\
\text { J.C. }\end{array}$ & $\begin{array}{l}\text { Sandy beach macrofaunal } \\
\text { assemblages as indicators of } \\
\text { anthropogenic impacts on coastal } \\
\text { dunes }\end{array}$ & Journal - Article & $\begin{array}{l}\text { Ecological } \\
\text { Indicators }\end{array}$ & 2013 & $196-204$ & - & - & 30 & en \\
\hline $\begin{array}{l}\text { Bunce, R.G.H., } \\
\text { Bogers, } \\
\text { M.M.B., } \\
\text { Evans, D., } \\
\text { Jongman, } \\
\text { R.H.G. }\end{array}$ & $\begin{array}{l}\text { Field identification of habitats } \\
\text { directive Annex I habitats as a } \\
\text { major European biodiversity } \\
\text { indicator }\end{array}$ & Journal - Article & $\begin{array}{l}\text { Ecological } \\
\text { Indicators }\end{array}$ & 2013 & $105-110$ & - & - & 33 & en \\
\hline $\begin{array}{l}\text { Campos, J.A., } \\
\text { Biurrun, I., } \\
\text { García- } \\
\text { Mijangos, I., } \\
\text { Loidi, J., } \\
\text { Herrera, M. }\end{array}$ & $\begin{array}{l}\text { Assessing the level of plant } \\
\text { invasion: A multi-scale approach } \\
\text { based on vegetation plots }\end{array}$ & Journal - Article & $\begin{array}{l}\text { Plant Biosystems - } \\
\text { An International } \\
\text { Journal Dealing } \\
\text { with all Aspects of } \\
\text { Plant Biology }\end{array}$ & 2013 & $\begin{array}{c}1148- \\
1162\end{array}$ & - & 4 & 147 & en \\
\hline $\begin{array}{l}\text { Del Vecchio, } \\
\text { S., Acosta, A., } \\
\text { Stanisci, A. }\end{array}$ & $\begin{array}{l}\text { The impact of Acacia saligna } \\
\text { invasion on Italian coastal dune EC } \\
\text { habitats }\end{array}$ & Journal - Article & $\begin{array}{l}\text { Comptes Rendus } \\
\text { Biologies }\end{array}$ & 2013 & $364-369$ & - & 7 & 336 & en \\
\hline $\begin{array}{l}\text { Eliáš, P., } \\
\text { Sopotlieva, D., } \\
\text { Dítě, D., } \\
\text { Hájková, P., } \\
\text { Apostolova, I., } \\
\text { Senko, D., } \\
\text { Melečková, Z., } \\
\text { Hájek, M. }\end{array}$ & $\begin{array}{l}\text { Vegetation diversity of salt-rich } \\
\text { grasslands in Southeast Europe }\end{array}$ & Journal - Article & $\begin{array}{l}\text { Applied } \\
\text { Vegetation } \\
\text { Science }\end{array}$ & 2013 & $521-537$ & - & 3 & 16 & en \\
\hline $\begin{array}{l}\text { Godet, L., } \\
\text { Thomas, A. }\end{array}$ & $\begin{array}{l}\text { Three centuries of land cover } \\
\text { changes in the largest French } \\
\text { Atlantic wetland provide new } \\
\text { insights for wetland conservation }\end{array}$ & Journal - Article & $\begin{array}{c}\text { Applied } \\
\text { Geography }\end{array}$ & 2013 & 133-139 & - & - & 42 & en \\
\hline $\begin{array}{l}\text { Henle, K., } \\
\text { Bauch, B., } \\
\text { Auliya, M., } \\
\text { Külvik, M., } \\
\text { Pe‘er, G., } \\
\text { Schmeller, D. } \\
\text { S., Framstad, } \\
\text { E. }\end{array}$ & $\begin{array}{l}\text { Priorities for biodiversity } \\
\text { monitoring in Europe: A review of } \\
\text { supranational policies and a novel } \\
\text { scheme for integrative } \\
\text { prioritization }\end{array}$ & Journal - Article & $\begin{array}{l}\text { Ecological } \\
\text { Indicators }\end{array}$ & 2013 & $5-18$ & - & - & 33 & en \\
\hline $\begin{array}{l}\text { Lepareur, F., } \\
\text { Bertrand, S., } \\
\text { Papuga, G., \& } \\
\text { Richeux, M. }\end{array}$ & $\begin{array}{l}\text { État de conservation de l'habitat } \\
1150 \text { «Lagunes côtières»: Méthode } \\
\text { d'évaluation à l'échelle du site } \\
\text { Natura } 2000 \text {-Guide d'application } \\
\text { Version } 1 .\end{array}$ & Report & $\begin{array}{l}\text { Service du } \\
\text { patrimoine naturel, } \\
\text { Muséum national } \\
\text { d'histoire naturelle }\end{array}$ & 2013 & - & 111 & - & - & $\mathrm{fr}$ \\
\hline
\end{tabular}




\begin{tabular}{|c|c|c|c|c|c|c|c|c|c|}
\hline $\begin{array}{l}\text { Malavasi, M., } \\
\text { Santoro, R., } \\
\text { Cutini, M., } \\
\text { Acosta, A.T.R., } \\
\text { Carranza, M.L. }\end{array}$ & $\begin{array}{l}\text { What has happened to coastal } \\
\text { dunes in the last half century? A } \\
\text { multitemporal coastal landscape } \\
\text { analysis in Central Italy }\end{array}$ & Journal - Article & $\begin{array}{l}\text { Landscape and } \\
\text { Urban Planning }\end{array}$ & 2013 & $54-63$ & - & - & 119 & en \\
\hline $\begin{array}{l}\text { Malvárez, G., } \\
\text { Jackson, D., } \\
\text { Navas, F., } \\
\text { Alonso, I., } \\
\text { Hernandez- } \\
\text { Calvento, L. }\end{array}$ & $\begin{array}{l}\text { A Conceptual Model for Dune } \\
\text { Morphodynamics of the Corralejo } \\
\text { Dune System, Fuerteventura, } \\
\text { Spain. }\end{array}$ & Journal - Article & $\begin{array}{l}\text { Journal of Coastal } \\
\text { Research }\end{array}$ & 2013 & $\begin{array}{c}1539- \\
1544\end{array}$ & - & $\mathrm{sp} 2$ & 65 & en \\
\hline $\begin{array}{l}\text { Martins, } \\
\text { Mónica C., } \\
\text { Neto, Carlos S., } \\
\text { Costa, José C. }\end{array}$ & $\begin{array}{l}\text { The meaning of mainland Portugal } \\
\text { beaches and dunes' psammophilic } \\
\text { plant communities: a contribution } \\
\text { to tourism management and nature } \\
\text { conservation }\end{array}$ & Journal - Article & $\begin{array}{l}\text { Journal of Coastal } \\
\text { Conservation }\end{array}$ & 2013 & 279-299 & - & 3 & 17 & en \\
\hline $\begin{array}{l}\text { Robins, N. S., } \\
\text { Pye, K., } \\
\text { Wallace, H. }\end{array}$ & $\begin{array}{l}\text { Dynamic coastal dune spit: the } \\
\text { impact of morphological change on } \\
\text { dune slacks at Whiteford Burrows, } \\
\text { South Wales, UK }\end{array}$ & Journal - Article & $\begin{array}{l}\text { Journal of Coastal } \\
\text { Conservation }\end{array}$ & 2013 & $473-482$ & - & 3 & 17 & en \\
\hline $\begin{array}{l}\text { Rodwell, J., } \\
\text { Janssen, J. A. } \\
\text { M., Gubbay, S., } \\
\text { Schaminée, J. } \\
\text { H. J. } \\
\end{array}$ & $\begin{array}{l}\text { Red List Assessment of European } \\
\text { Habitat Types - A feasibility study } \\
\text { - }\end{array}$ & Report & $\begin{array}{c}\text { Alterra } \\
\text { Wageningen UR }\end{array}$ & 2013 & 79 & - & - & - & en \\
\hline $\begin{array}{l}\text { Ward, R. D., } \\
\text { Burnside, N. } \\
\text { G., Joyce, C. } \\
\text { B., Sepp, K. }\end{array}$ & $\begin{array}{l}\text { The use of medium point density } \\
\text { LiDAR elevation data to determine } \\
\text { plant community types in Baltic } \\
\text { coastal wetlands }\end{array}$ & Journal - Article & $\begin{array}{l}\text { Ecological } \\
\text { Indicators }\end{array}$ & 2013 & $96-104$ & - & - & 33 & en \\
\hline $\begin{array}{l}\text { Bertacchi, A., } \\
\text { Lombardi, T. }\end{array}$ & $\begin{array}{l}\text { Diachronic analysis (1954-2010) } \\
\text { of transformations of the dune } \\
\text { habitat in a stretch of the Northern } \\
\text { Tyrrhenian Coast (Italy) }\end{array}$ & Journal - Article & $\begin{array}{l}\text { Plant Biosystems - } \\
\text { An International } \\
\text { Journal Dealing } \\
\text { with all Aspects of } \\
\text { Plant Biology }\end{array}$ & 2014 & $227-236$ & - & 2 & 148 & en \\
\hline $\begin{array}{l}\text { Brus, D.J., } \\
\text { Slim, P.A., } \\
\text { Heidema, A.H., } \\
\text { van Dobben, } \\
\text { H.F. } \\
\end{array}$ & $\begin{array}{l}\text { Trend monitoring of the areal } \\
\text { extent of habitats in a subsiding } \\
\text { coastal area by spatial probability } \\
\text { sampling }\end{array}$ & Journal - Article & $\begin{array}{l}\text { Ecological } \\
\text { Indicators }\end{array}$ & 2014 & $313-319$ & - & - & 45 & en \\
\hline Chefaoui, R.M. & $\begin{array}{l}\text { Landscape metrics as indicators of } \\
\text { coastal morphology: A multi-scale } \\
\text { approach }\end{array}$ & Journal - Article & $\begin{array}{l}\text { Ecological } \\
\text { Indicators }\end{array}$ & 2014 & $139-147$ & - & - & 45 & en \\
\hline Ciccarelli, D. & $\begin{array}{l}\text { Mediterranean Coastal Sand Dune } \\
\text { Vegetation: Influence of Natural } \\
\text { and Anthropogenic Factors }\end{array}$ & Journal - Article & $\begin{array}{c}\text { Environmental } \\
\text { Management }\end{array}$ & 2014 & 194-204 & - & 2 & 54 & en \\
\hline $\begin{array}{l}\text { García-Madrid, } \\
\text { A.S., Molina, } \\
\text { J.A., Cantó, P. }\end{array}$ & $\begin{array}{l}\text { Classification of habitats highlights } \\
\text { priorities for conservation policies: } \\
\text { The case of Spanish Mediterranean } \\
\text { tall humid herb grasslands }\end{array}$ & Journal - Article & $\begin{array}{l}\text { Journal for Nature } \\
\text { Conservation }\end{array}$ & 2014 & $142-156$ & - & 2 & 22 & en \\
\hline
\end{tabular}




\begin{tabular}{|c|c|c|c|c|c|c|c|c|c|}
\hline $\begin{array}{l}\text { Genovesi, P., } \\
\text { Angelini, P., } \\
\text { Bianchi, E., } \\
\text { Dupre,' E., } \\
\text { Ercole, S., } \\
\text { Giacanelli, V., } \\
\text { Ronchi, F., } \\
\text { Stoch, F. }\end{array}$ & $\begin{array}{l}\text { Specie e habitat di interesse } \\
\text { comunitario in Italia: distribuzione, } \\
\text { stato di conservazione e trend }\end{array}$ & book & $\begin{array}{c}\text { ISPRA, serie } \\
\text { Rapporti 194-2014 }\end{array}$ & 2014 & - & 194 & - & - & it \\
\hline $\begin{array}{l}\text { Hladik C. \& } \\
\text { Alber M. }\end{array}$ & $\begin{array}{l}\text { Classification of salt marsh } \\
\text { vegetation using edaphic and } \\
\text { remote } \\
\text { sensing-derived variables }\end{array}$ & Journal - Article & $\begin{array}{l}\text { Estuarine, Coastal } \\
\text { and Shelf Science }\end{array}$ & 2014 & $47-57$ & - & - & 141 & en \\
\hline $\begin{array}{l}\text { Janssen, } \\
\text { J.A.M., Weeda, } \\
\text { E. J., } \\
\text { Schippers, P., } \\
\text { Bijlsma, R. J., } \\
\text { Schaminée, J. } \\
\text { H. J., Arts, G. } \\
\text { H. P., } \\
\text { Deerenberg C., } \\
\text { Jak, R.G. } \\
\end{array}$ & $\begin{array}{l}\text { Habitattypen in Natura 2000- } \\
\text { gebieden }\end{array}$ & Report & $\begin{array}{l}\text { Wot-technical } \\
\text { report } 8\end{array}$ & 2014 & - & 199 & - & - & en \\
\hline $\begin{array}{l}\text { Pintó, J., Martí, } \\
\text { C., Fraguell, } \\
\text { R.M. } \\
\end{array}$ & $\begin{array}{l}\text { Assessing Current Conditions of } \\
\text { Coastal Dune Systems of } \\
\text { Mediterranean Developed Shores } \\
\end{array}$ & Journal - Article & $\begin{array}{l}\text { Journal of Coastal } \\
\text { Research }\end{array}$ & 2014 & $832-842$ & - & 4 & 30 & en \\
\hline $\begin{array}{l}\text { Pye, K., Blott, } \\
\text { S.J., Howe, } \\
\text { M.A. }\end{array}$ & $\begin{array}{l}\text { Coastal dune stabilization in Wales } \\
\text { and requirements for rejuvenation }\end{array}$ & Journal - Article & $\begin{array}{l}\text { Journal of Coastal } \\
\text { Conservation }\end{array}$ & 2014 & $27-54$ & - & 1 & 18 & en \\
\hline \begin{tabular}{l|} 
Rapinel, S., \\
Clément, B., \\
Magnanon, S., \\
Sellin, V., \\
Hubert-Moy, L. \\
\end{tabular} & $\begin{array}{l}\text { Identification and mapping of } \\
\text { natural vegetation on a coastal site } \\
\text { using a Worldview-2 satellite } \\
\text { image }\end{array}$ & Journal - Article & $\begin{array}{c}\text { Journal of } \\
\text { Environmental } \\
\text { Management }\end{array}$ & 2014 & $236-246$ & - & - & 144 & en \\
\hline $\begin{array}{l}\text { Ruocco, M., } \\
\text { Bertoni, D., } \\
\text { Sarti, G., } \\
\text { Ciccarelli, D. }\end{array}$ & $\begin{array}{l}\text { Mediterranean coastal dune } \\
\text { systems: Which abiotic factors } \\
\text { have the most influence on plant } \\
\text { communities? }\end{array}$ & Journal - Article & $\begin{array}{l}\text { Estuarine, Coastal } \\
\text { and Shelf Science }\end{array}$ & 2014 & $213-222$ & - & - & 149 & en \\
\hline $\begin{array}{l}\text { Ssymank A., } \\
\text { Ellwanger G., } \\
\text { Ihl A. \& } \\
\text { Carsten } \\
\text { Burggraf C. }\end{array}$ & $\begin{array}{l}\text { Krite Öffentlichkeitsbeteiligung } \\
\text { und -information beim } \\
\text { Management des } \\
\text { Schutzgebietsnetzes Natura } 2000\end{array}$ & Journal - Article & $\begin{array}{l}\text { Natur und } \\
\text { Landschaft }\end{array}$ & 2014 & $264-270$ & - & 6 & 89 & de \\
\hline $\begin{array}{l}\text { Stanisci, A., } \\
\text { Acosta, A. T. } \\
\text { R., Carranza, } \\
\text { M. L., De } \\
\text { Chiro, M., Del } \\
\text { Vecchio, S., Di } \\
\text { Martino, L., } \\
\text { Frattaroli A.R., } \\
\text { Fusco S., Izzi } \\
\text { C.F., Pirone G., } \\
\text { Prisco, I. }\end{array}$ & $\begin{array}{l}\text { EU habitats monitoring along the } \\
\text { coastal dunes of the LTER sites of } \\
\text { Abruzzo and Molise (Italy) }\end{array}$ & Journal - Article & Plant Sociology & 2014 & $51-56$ & - & 1 & 51 & en \\
\hline $\begin{array}{l}\text { Ondiviela B., } \\
\text { Recio M., } \\
\text { Juanes J.A. } \\
\end{array}$ & $\begin{array}{l}\text { A management approach for the } \\
\text { ecological integrity of NE Atlantic } \\
\text { estuaries }\end{array}$ & Journal - Article & $\begin{array}{l}\text { Ecological } \\
\text { Indicators }\end{array}$ & 2015 & - & - & - & - & - \\
\hline $\begin{array}{l}\text { Bio, A., Bastos, } \\
\text { L., Granja, H., } \\
\text { Pinho, J.L.S., } \\
\text { Gonçalves, } \\
\text { J.A., } \\
\text { Henriques, R., } \\
\text { Madeira, S., } \\
\text { Magalhães, A., } \\
\text { Rodrigues, D. } \\
\end{array}$ & $\begin{array}{l}\text { Methods for coastal monitoring } \\
\text { and erosion risk assessment: two } \\
\text { Portuguese case studies }\end{array}$ & Journal - Article & $\begin{array}{l}\text { Revista de Gestão } \\
\text { Costeira Integrada }\end{array}$ & 2015 & $47-63$ & - & - & 15 & en \\
\hline $\begin{array}{l}\text { Del Vecchio, } \\
\text { S., Prisco, I., } \\
\text { Acosta, A.T.R., } \\
\text { Stanisci, A. }\end{array}$ & $\begin{array}{l}\text { Changes in plant species } \\
\text { composition of coastal dune } \\
\text { habitats over a } 20 \text {-year period }\end{array}$ & Journal - Article & AoB Plants & 2015 & $1-10$ & - & - & 7 & en \\
\hline Delbosc, P. & $\begin{array}{l}\text { Phytosociologie dynamico-caténale } \\
\text { des végétations de la Corse : }\end{array}$ & Thesis & $\begin{array}{l}\text { Thesis / Doctorat } \\
\text { thesis. Brest. }\end{array}$ & 2015 & - & 698 & - & - & fr \\
\hline
\end{tabular}




\begin{tabular}{|c|c|c|c|c|c|c|c|c|c|}
\hline & $\begin{array}{l}\text { méthodologies typologique et } \\
\text { cartographique }\end{array}$ & & & & & & & & \\
\hline $\begin{array}{l}\text { Gutierres, F., } \\
\text { Gabriel, L., } \\
\text { Emidio, A., } \\
\text { Mendes, P., } \\
\text { Neto, C., Reis, } \\
\text { E. }\end{array}$ & $\begin{array}{l}\text { Modelling the Potential natural } \\
\text { vegetation in the Loures } \\
\text { Municipality (Lisbon Metropolitan } \\
\text { Area) }\end{array}$ & Journal - Article & $\begin{array}{l}\text { Finisterra-Revista } \\
\text { Portuguesa de } \\
\text { Geografia }\end{array}$ & 2015 & $31-62$ & - & 99 & 50 & en \\
\hline $\begin{array}{l}\text { Jiménez- } \\
\text { Alfaro, B., } \\
\text { Marcenò, C., } \\
\text { Guarino, R., } \\
\text { Chytrý, M. }\end{array}$ & $\begin{array}{l}\text { Regional metacommunities in two } \\
\text { coastal systems: spatial structure } \\
\text { and drivers of plant assemblages }\end{array}$ & Journal - Article & $\begin{array}{c}\text { Journal of } \\
\text { Biogeography }\end{array}$ & 2015 & $452-462$ & - & 3 & 42 & en \\
\hline Klemas, V.V. & $\begin{array}{l}\text { Coastal and Environmental Remote } \\
\text { Sensing from Unmanned Aerial } \\
\text { Vehicles: An Overview }\end{array}$ & Journal - Article & $\begin{array}{l}\text { Journal of Coastal } \\
\text { Research }\end{array}$ & 2015 & $\begin{array}{l}1260- \\
1267\end{array}$ & - & 5 & 31 & en \\
\hline $\begin{array}{l}\text { Meyer, S., } \\
\text { Bergmeier, E., } \\
\text { Becker, T., } \\
\text { Wesche, K., } \\
\text { Krause, B., } \\
\text { Leuschner, C. }\end{array}$ & $\begin{array}{l}\text { Detecting long-term losses at the } \\
\text { plant community level - arable } \\
\text { fields in Germany revisited }\end{array}$ & Journal - Article & $\begin{array}{l}\text { Applied } \\
\text { Vegetation } \\
\text { Science }\end{array}$ & 2015 & $432-442$ & - & 3 & 18 & en \\
\hline $\begin{array}{l}\text { Ondiviela, B., } \\
\text { Recio, M., } \\
\text { Juanes, J.A. }\end{array}$ & $\begin{array}{l}\text { A management approach for the } \\
\text { ecological integrity of NE Atlantic } \\
\text { estuaries }\end{array}$ & Journal - Article & $\begin{array}{l}\text { Ecological } \\
\text { Indicators }\end{array}$ & 2015 & $105-115$ & - & - & 52 & en \\
\hline $\begin{array}{l}\text { Pinna, M. S., } \\
\text { Canadas, E. } \\
\text { M., Fenu, G., } \\
\text { \& Bacchetta, } \\
\text { G. }\end{array}$ & $\begin{array}{l}\text { The European Juniperus habitat in } \\
\text { the Sardinian coastal dunes: } \\
\text { Implication for conservation }\end{array}$ & Journal - Article & $\begin{array}{l}\text { Estuarine, Coastal } \\
\text { and Shelf Science }\end{array}$ & 2015 & $214-220$ & - & - & 164 & en \\
\hline $\begin{array}{l}\text { Pinna, M. S., } \\
\text { Cogoni, D., } \\
\text { Fenu, G., \& } \\
\text { Bacchetta, G. }\end{array}$ & $\begin{array}{l}\text { The conservation status and } \\
\text { anthropogenic impacts assessments } \\
\text { of Mediterranean coastal dunes }\end{array}$ & Journal - Article & $\begin{array}{l}\text { Estuarine, Coastal } \\
\text { and Shelf Science }\end{array}$ & 2015 & $25-31$ & - & - & 167 & en \\
\hline $\begin{array}{l}\text { Sciandrello, S., } \\
\text { Tomaselli, G., } \\
\text { Minissale, P. }\end{array}$ & $\begin{array}{l}\text { The role of natural vegetation in } \\
\text { the analysis of the spatio-temporal } \\
\text { changes of coastal dune system: a } \\
\text { case study in Sicily }\end{array}$ & Journal - Article & $\begin{array}{l}\text { Journal of Coastal } \\
\text { Conservation }\end{array}$ & 2015 & $199-212$ & - & 2 & 19 & en \\
\hline $\begin{array}{l}\text { Valentini, E., } \\
\text { Taramelli, A., } \\
\text { Filipponi, F., } \\
\text { Giulio, S. }\end{array}$ & $\begin{array}{l}\text { An effective procedure for EUNIS } \\
\text { and Natura } 2000 \text { habitat type } \\
\text { mapping in estuarine ecosystems } \\
\text { integrating ecological knowledge } \\
\text { and remote sensing analysis }\end{array}$ & Journal - Article & $\begin{array}{l}\text { Ocean \& Coastal } \\
\text { Management }\end{array}$ & 2015 & $52-64$ & - & - & 108 & en \\
\hline $\begin{array}{l}\text { Zlinszky, A., } \\
\text { Deák, B., } \\
\text { Kania, A., } \\
\text { Schroiff, A., \& } \\
\text { Pfeifer, N. } \\
\end{array}$ & $\begin{array}{l}\text { Mapping Natura } 2000 \text { habitat } \\
\text { conservation status in a pannonic } \\
\text { salt steppe with airborne laser } \\
\text { scanning. }\end{array}$ & Journal - Article & Remote Sensing & 2015 & $\begin{array}{l}2991- \\
3019\end{array}$ & - & 7 & 3 & en \\
\hline
\end{tabular}




\begin{tabular}{|c|c|c|c|c|c|c|c|c|c|}
\hline $\begin{array}{l}\text { Adamo, M., } \\
\text { Tarantino, C., } \\
\text { Tomaselli, V., } \\
\text { Veronico, G., } \\
\text { Nagendra, H., } \\
\text { \& Blonda, P. }\end{array}$ & $\begin{array}{l}\text { Habitat mapping of coastal } \\
\text { wetlands using expert knowledge } \\
\text { and Earth observation data }\end{array}$ & Journal - Article & $\begin{array}{c}\text { Journal of Applied } \\
\text { Ecology }\end{array}$ & 2016 & $\begin{array}{l}1521- \\
1532\end{array}$ & - & 5 & 53 & en \\
\hline $\begin{array}{l}\text { Asensi, A., } \\
\text { Díez-Garretas, } \\
\text { B., Pereña, J. }\end{array}$ & $\begin{array}{l}\text { Alien plants of coastal dune } \\
\text { habitats in southern Spain }\end{array}$ & Journal - Article & $\begin{array}{l}\text { Plant Biosystems - } \\
\text { An International } \\
\text { Journal Dealing } \\
\text { with all Aspects of } \\
\text { Plant Biology }\end{array}$ & 2016 & $477-483$ & - & 3 & 150 & en \\
\hline $\begin{array}{l}\text { Bazzichetto, } \\
\text { M., Malavasi, } \\
\text { M., Acosta, } \\
\text { A.T.R., } \\
\text { Carranza, M.L. }\end{array}$ & $\begin{array}{l}\text { How does dune morphology shape } \\
\text { coastal EC habitats occurrence? A } \\
\text { remote sensing approach using } \\
\text { airborne LiDAR on the } \\
\text { Mediterranean coast }\end{array}$ & Journal - Article & $\begin{array}{l}\text { Ecological } \\
\text { Indicators }\end{array}$ & 2016 & $618-626$ & - & - & 71 & en \\
\hline $\begin{array}{l}\text { Bilkovic, D.M., } \\
\text { Mitchell, M., } \\
\text { Mason, P. \& } \\
\text { Duhring, K., }\end{array}$ & $\begin{array}{l}\text { The Role of Living Shorelines as } \\
\text { Estuarine Habitat Conservation } \\
\text { Strategies }\end{array}$ & Journal - Article & $\begin{array}{c}\text { Coastal } \\
\text { Management }\end{array}$ & 2016 & $161-174$ & - & - & 44 & en \\
\hline $\begin{array}{l}\text { Del Vecchio, } \\
\text { S., Slaviero, A., } \\
\text { Fantinato, E., } \\
\text { Buffa, G. } \\
\end{array}$ & $\begin{array}{l}\text { The use of plant community } \\
\text { attributes to detect habitat quality } \\
\text { in coastal environments }\end{array}$ & Journal - Article & AoB Plants & 2016 & $1-14$ & - & - & 8 & en \\
\hline Demartini, C. & $\begin{array}{l}\text { Les végétations des cotes Manche- } \\
\text { Atlantique francaises :essai de } \\
\text { typologie et de cartographie } \\
\text { dynamico-catenales }\end{array}$ & Thesis & $\begin{array}{l}\text { Thesis / Doctorat } \\
\text { thesis. Brest. }\end{array}$ & 2016 & - & 671 & - & - & $\mathrm{fr}$ \\
\hline \begin{tabular}{l|} 
Duarte, I., \\
Rego, F.C., \\
Casquilho, J.P., \\
Arsénio, P. \\
\end{tabular} & $\begin{array}{l}\text { A Relevance Index for the habitat } \\
\text { areas of Natura } 2000 \text { Network } \\
\text { based on their Rarity and } \\
\text { Representativeness }\end{array}$ & Journal - Article & $\begin{array}{l}\text { Ecological } \\
\text { Indicators }\end{array}$ & 2016 & $202-213$ & - & - & 61 & en \\
\hline $\begin{array}{l}\text { European } \\
\text { Commission, } \\
\text { Directorate- } \\
\text { General for the } \\
\text { Environment }\end{array}$ & $\begin{array}{l}\text { Mapping and assessment of } \\
\text { ecosystems and their services } \\
\text { mapping and assessing the } \\
\text { condition of Europe's ecosystems: } \\
\text { progress and challenges : 3rd } \\
\text { report - final, March } 2016 \text {. }\end{array}$ & book & $\begin{array}{l}\text { European Union, } \\
2016\end{array}$ & 2016 & - & 179 & - & - & en \\
\hline $\begin{array}{l}\text { Gigante, D., } \\
\text { Foggi, B., } \\
\text { Venanzoni, R., } \\
\text { Viciani, D., \& } \\
\text { Buffa, G. } \\
\end{array}$ & $\begin{array}{l}\text { Habitats on the grid: The spatial } \\
\text { dimension does matter for red- } \\
\text { listing }\end{array}$ & Journal - Article & $\begin{array}{l}\text { Journal for Nature } \\
\text { Conservation }\end{array}$ & 2016 & $1-9$ & - & - & 32 & en \\
\hline $\begin{array}{l}\text { Gutierres, F., } \\
\text { Teodoro, A. C., } \\
\text { Reis, E., Neto, } \\
\text { C., Costa, J. C. }\end{array}$ & $\begin{array}{l}\text { Remote Sensing Technologies for } \\
\text { the Assessment of Marine and } \\
\text { Coastal Ecosystems }\end{array}$ & Journal - Article & $\begin{array}{l}\text { apping along } \\
\text { Continental } \\
\text { Shelves }\end{array}$ & 2016 & $69-104$ & - & - & 13 & en \\
\hline $\begin{array}{l}\text { Hulisz, P., } \\
\text { Piernik, A., } \\
\text { Mantilla- } \\
\text { Contreras, J., } \\
\text { Elvisto, T. }\end{array}$ & $\begin{array}{l}\text { Main Driving Factors for Seacoast } \\
\text { Vegetation in the Southern and } \\
\text { Eastern Baltic }\end{array}$ & Journal - Article & Wetlands & 2016 & 909-919 & - & 5 & 36 & en \\
\hline $\begin{array}{l}\text { Jasprica, N., } \\
\text { Milović, M., } \\
\text { Kovačić, S., } \\
\text { Stamenković, } \\
\text { V. }\end{array}$ & $\begin{array}{l}\text { Phytocoenotic diversity of the NE- } \\
\text { Adriatic island of Olib }\end{array}$ & Journal - Article & Plant Sociology & 2016 & $53-78$ & - & 1 & 53 & en \\
\hline
\end{tabular}




\begin{tabular}{|c|c|c|c|c|c|c|c|c|c|}
\hline $\begin{array}{l}\text { Maciejewski, } \\
\text { L., Lepareur, } \\
\text { F., Viry, D., } \\
\text { Bensettiti, F., } \\
\text { Puissauve, R., } \\
\text { Touroult, J. }\end{array}$ & $\begin{array}{l}\text { État de conservation des habitats: } \\
\text { propositions de définitions et de } \\
\text { concepts pour l'évaluation à } \\
\text { l'échelle d'un site Natura } 2000 \text {. }\end{array}$ & Journal - Article & Revue d'écologie & 2016 & $3-20$ & - & 1 & 71 & $\mathrm{fr}$ \\
\hline $\begin{array}{l}\text { Mahdavi, P., } \\
\text { Bergmeier, E. }\end{array}$ & $\begin{array}{l}\text { Plant functional traits and diversity } \\
\text { in sand dune ecosystems across } \\
\text { different biogeographic regions }\end{array}$ & Journal - Article & Acta Oecologica & 2016 & $37-45$ & - & - & 74 & en \\
\hline $\begin{array}{l}\text { Malavasi, M., } \\
\text { Santoro, R., } \\
\text { Cutini, M., } \\
\text { Acosta, A.T.R., } \\
\text { Carranza, M.L. }\end{array}$ & $\begin{array}{l}\text { The impact of human pressure on } \\
\text { landscape patterns and plant } \\
\text { species richness in Mediterranean } \\
\text { coastal dunes }\end{array}$ & Journal - Article & $\begin{array}{l}\text { Plant Biosystems - } \\
\text { An International } \\
\text { Journal Dealing } \\
\text { with all Aspects of } \\
\text { Plant Biology }\end{array}$ & 2016 & $73-82$ & - & 1 & 150 & en \\
\hline $\begin{array}{l}\text { Marcenò, C., \& } \\
\text { Jiménez- } \\
\text { Alfaro, B. }\end{array}$ & $\begin{array}{l}\text { The Mediterranean Ammophiletea } \\
\text { Database: a comprehensive dataset } \\
\text { of coastal dune vegetation }\end{array}$ & Journal - Article & Phytocoenologia & 2016 & $2-11$ & - & - & - & en \\
\hline $\begin{array}{l}\text { Prisco, I., } \\
\text { Stanisci, A., } \\
\text { Acosta, A.T.R }\end{array}$ & $\begin{array}{l}\text { Mediterranean dunes on the go: } \\
\text { Evidence from a short term study } \\
\text { on coastal herbaceous vegetation }\end{array}$ & Journal - Article & $\begin{array}{l}\text { Estuarine, Coastal } \\
\text { and Shelf Science }\end{array}$ & 2016 & $40-46$ & - & - & 182 & en \\
\hline $\begin{array}{l}\text { Prisco, Irene, } \\
\text { Carboni, Marta, } \\
\text { Jucker, } \\
\text { Tommaso, } \\
\text { Acosta, Alicia } \\
\text { T.R. }\end{array}$ & $\begin{array}{l}\text { Temporal changes in the } \\
\text { vegetation of Italian coastal dunes: } \\
\text { identifying winners and losers } \\
\text { through the lens of functional traits }\end{array}$ & Journal - Article & $\begin{array}{l}\text { Journal of Applied } \\
\text { Ecology }\end{array}$ & 2016 & $\begin{array}{c}1533- \\
1542\end{array}$ & - & 5 & 53 & en \\
\hline $\begin{array}{l}\text { Šilc, U., } \\
\text { Mullaj, A., } \\
\text { Alegro, A., } \\
\text { Ibraliu, A., } \\
\text { Dajić } \\
\text { Stevanović, Z., } \\
\text { Luković, M., } \\
\text { Stešević, D. }\end{array}$ & $\begin{array}{l}\text { Sand dune vegetation along the } \\
\text { eastern Adriatic coast. }\end{array}$ & Journal - Article & Phytocoenologia & 2016 & $339-355$ & - & 4 & 46 & en \\
\hline $\begin{array}{l}\text { Viciani, D., } \\
\text { Dell'Olmo, L., } \\
\text { Ferretti, G., } \\
\text { Lazzaro, L., } \\
\text { Lastrucci, L., } \\
\text { Foggi, B. }\end{array}$ & $\begin{array}{l}\text { Detailed Natura } 2000 \text { and } \\
\text { CORINE Biotopes habitat maps of } \\
\text { the island of Elba (Tuscan } \\
\text { Archipelago, Italy) }\end{array}$ & Journal - Article & Journal of Maps & 2016 & $492-502$ & - & 3 & 12 & en \\
\hline $\begin{array}{l}\text { Zhao, Q., Bai, } \\
\text { J., Huang, L., } \\
\text { Gu, B., Lu, Q., } \\
\text { \& Gao, Z. }\end{array}$ & $\begin{array}{l}\text { A review of methodologies and } \\
\text { success indicators for coastal } \\
\text { wetland restoration }\end{array}$ & Journal - Article & $\begin{array}{l}\text { Ecological } \\
\text { Indicators }\end{array}$ & 2016 & $442-452$ & - & - & 60 & en \\
\hline $\begin{array}{l}\text { Almeida, D., } \\
\text { Neto, C., \& } \\
\text { Costa, J. C. }\end{array}$ & $\begin{array}{l}\text { Active or passive recovery? } \\
\text { Discussing implications of } \\
\text { vegetation diversity in unmanaged } \\
\text { salt marshes }\end{array}$ & Journal - Article & $\begin{array}{l}\text { Estuarine, Coastal } \\
\text { and Shelf Science }\end{array}$ & 2017 & $201-208$ & - & - & 191 & en \\
\hline $\begin{array}{l}\text { Borre, J. V., } \\
\text { Spanhove, T., } \\
\text { Haest, B. }\end{array}$ & $\begin{array}{l}\text { Towards a Mature Age of Remote } \\
\text { Sensing for Natura } 2000 \text { Habitat } \\
\text { Conservation: Poor Method } \\
\text { Transferability as a Prime Obstacle }\end{array}$ & bookSection & $\begin{array}{c}\text { The Roles of } \\
\text { Remote Sensing in } \\
\text { Nature } \\
\text { Conservation }\end{array}$ & 2017 & $11-37$ & - & - & - & en \\
\hline
\end{tabular}




\begin{tabular}{|c|c|c|c|c|c|c|c|c|c|}
\hline $\begin{array}{l}\text { Brady, A.F. \& } \\
\text { Boda, C.S. }\end{array}$ & $\begin{array}{l}\text { How do we know if managed } \\
\text { realignment for coastal habitat } \\
\text { compensation is successful? } \\
\text { Insights from the implementation } \\
\text { of the EU Birds and Habitats } \\
\text { Directive in England }\end{array}$ & Journal - Article & $\begin{array}{l}\text { Ocean \& Coastal } \\
\text { Management }\end{array}$ & 2017 & $164-174$ & - & - & 143 & en \\
\hline $\begin{array}{l}\text { Brownett, J., } \\
\text { Mills, R. }\end{array}$ & $\begin{array}{l}\text { The development and application } \\
\text { of remote sensing to monitor sand } \\
\text { dune habitats }\end{array}$ & Journal - Article & $\begin{array}{l}\text { Journal of Coastal } \\
\text { Conservation }\end{array}$ & 2017 & $643-656$ & - & 5 & 21 & en \\
\hline $\begin{array}{l}\text { Cappucci, S., } \\
\text { Valentini, E., } \\
\text { Monte, M. Del, } \\
\text { Paci, M., } \\
\text { Filipponi, F., } \\
\text { Taramelli, A. }\end{array}$ & $\begin{array}{l}\text { Detection of Natural and Anthropic } \\
\text { Features on Small Islands }\end{array}$ & Journal - Article & $\begin{array}{l}\text { Journal of Coastal } \\
\text { Research }\end{array}$ & 2017 & $73-87$ & - & - & 77 & en \\
\hline $\begin{array}{l}\text { Ciccarelli, D., } \\
\text { Pinna, M.S., } \\
\text { Alquini, F., } \\
\text { Cogoni, D., } \\
\text { Ruocco, M., } \\
\text { Bacchetta, G., } \\
\text { Sarti, G., Fenu, } \\
\text { G. }\end{array}$ & $\begin{array}{l}\text { Development of a coastal dune } \\
\text { vulnerability index for } \\
\text { Mediterranean ecosystems: A } \\
\text { useful tool for coastal managers? }\end{array}$ & Journal - Article & $\begin{array}{l}\text { Estuarine, Coastal } \\
\text { and Shelf Science }\end{array}$ & 2017 & $84-95$ & - & - & 187 & en \\
\hline $\begin{array}{l}\text { Delbosc, P, } \\
\text { Bioret, F., } \\
\text { Panaïotis, C. }\end{array}$ & $\begin{array}{l}\text { Heritage assessment of vegetation } \\
\text { series of Corsica }\end{array}$ & Journal - Article & Plant sociology & 2017 & $3-12$ & - & 2 & 54 & en \\
\hline $\begin{array}{l}\text { DG } \\
\text { Environment }\end{array}$ & $\begin{array}{l}\text { Reporting under Article } 17 \text { of the } \\
\text { Habitats Directive: Explanatory } \\
\text { notes and guidelines for the period } \\
\text { 2013-2018 }\end{array}$ & Report & Report, Brussels & 2017 & $1-188$ & - & - & - & en \\
\hline $\begin{array}{l}\text { Doxa, A., } \\
\text { Albert, C.H., } \\
\text { Leriche, A., } \\
\text { Saatkamp, A. }\end{array}$ & $\begin{array}{l}\text { Prioritizing conservation areas for } \\
\text { coastal plant diversity under } \\
\text { increasing urbanization }\end{array}$ & Journal - Article & $\begin{array}{c}\text { Journal of } \\
\text { Environmental } \\
\text { Management }\end{array}$ & 2017 & $425-434$ & - & - & 201 & en \\
\hline $\begin{array}{l}\text { Garbutt, A., de } \\
\text { Groot, A., } \\
\text { Smit, C., } \\
\text { Pétillon, J. }\end{array}$ & $\begin{array}{l}\text { European salt marshes: ecology } \\
\text { and conservation in a changing } \\
\text { world }\end{array}$ & Journal - Article & $\begin{array}{l}\text { Journal of Coastal } \\
\text { Conservation }\end{array}$ & 2017 & $405-408$ & - & 3 & 21 & en \\
\hline $\begin{array}{l}\text { García-Ayllón } \\
\text { S. }\end{array}$ & $\begin{array}{l}\text { Diagnosis of complex coastal } \\
\text { ecological systems: Environmental } \\
\text { GIS analysis of a highly stressed } \\
\text { Mediterranean lagoon through } \\
\text { patiotemporal indicators }\end{array}$ & Journal - Article & $\begin{array}{l}\text { Ecological } \\
\text { Indicators }\end{array}$ & 2017 & $451-462$ & - & - & 83 & en \\
\hline $\begin{array}{l}\text { García-Ayllón, } \\
\text { S. }\end{array}$ & $\begin{array}{l}\text { Diagnosis of complex coastal } \\
\text { ecological systems: Environmental } \\
\text { GIS analysis of a highly stressed } \\
\text { Mediterranean lagoon through } \\
\text { spatiotemporal indicators }\end{array}$ & Journal - Article & $\begin{array}{l}\text { Ecological } \\
\text { Indicators }\end{array}$ & 2017 & $451-462$ & - & - & 83 & en \\
\hline $\begin{array}{l}\text { Duhalde, M., } \\
\text { Levrel, H., } \\
\text { Guyader, O., }\end{array}$ & $\begin{array}{l}\text { Is the choice of conservation } \\
\text { measures influenced by the } \\
\text { targeted natural habitats? The case } \\
\text { of French coastal Natura } 2000 \\
\text { sites. }\end{array}$ & book & $\begin{array}{l}\text { Ocean \& Coastal } \\
\text { Management }\end{array}$ & 2017 & $15-27$ & 142 & - & - & en \\
\hline $\begin{array}{l}\text { Hernández- } \\
\text { Cordero, A.I., } \\
\text { Hernández- } \\
\text { Calvento, L., } \\
\text { Espino, E.P.C. }\end{array}$ & $\begin{array}{l}\text { Vegetation changes as an indicator } \\
\text { of impact from tourist development } \\
\text { in an arid transgressive coastal } \\
\text { dune field }\end{array}$ & Journal - Article & Land Use Policy & 2017 & $479-491$ & - & - & 64 & en \\
\hline $\begin{array}{l}\text { Jones, A. R., } \\
\text { Schlacher, T. } \\
\text { A., Schoeman, } \\
\text { D. S., Weston, } \\
\text { M. A., } \\
\text { Withycombe, } \\
\text { G. M. }\end{array}$ & $\begin{array}{l}\text { Ecological research questions to } \\
\text { inform policy and the management } \\
\text { of sandy beaches }\end{array}$ & Journal - Article & $\begin{array}{l}\text { Ocean \& Coastal } \\
\text { Management }\end{array}$ & 2017 & $158-163$ & - & - & 148 & en \\
\hline
\end{tabular}




\begin{tabular}{|c|c|c|c|c|c|c|c|c|c|}
\hline $\begin{array}{l}\text { Kallimanis, A. } \\
\text { S., Panitsa, M., } \\
\text { Dimopoulos, P. }\end{array}$ & $\begin{array}{l}\text { Quality of non-expert citizen } \\
\text { science data collected for habitat } \\
\text { type conservation status } \\
\text { assessment in Natura } 2000 \\
\text { protected areas }\end{array}$ & Journal - Article & Scientific Reports & 2017 & & - & 1 & 7 & en \\
\hline $\begin{array}{l}\text { Mahdavi, P., } \\
\text { Isermann, M., } \\
\text { Bergmeier, E. }\end{array}$ & \begin{tabular}{|l|} 
Sand habitats across \\
biogeographical regions at species, \\
community and functional level \\
\end{tabular} & Journal - Article & Phytocoenologia & 2017 & $139-165$ & - & 2 & 47 & en \\
\hline $\begin{array}{l}\text { Marignani, M., } \\
\text { Bruschi, D., } \\
\text { Astiaso Garcia, } \\
\text { D., Frondoni, } \\
\text { R., Carli, E., } \\
\text { Pinna, M.S., } \\
\text { Cumo, F., } \\
\text { Gugliermetti, } \\
\text { F., Saatkamp, } \\
\text { A., Doxa, A., } \\
\text { Queller, Emi } \\
\text { M., Chaieb, M., } \\
\text { Bou Dagher- } \\
\text { Kharrat, M., El } \\
\text { Zein, R., El } \\
\text { Jeitani, S., } \\
\text { Khater, C., } \\
\text { Mansour, S., } \\
\text { Al-Shami, A., } \\
\text { Harik, G., } \\
\text { Alameddine, I. } \\
\text { el-Fadel, M., } \\
\text { Blasi, C. }\end{array}$ & $\begin{array}{l}\text { Identification and prioritization of } \\
\text { areas with high environmental risk } \\
\text { in Mediterranean coastal areas: A } \\
\text { flexible approach }\end{array}$ & Journal - Article & $\begin{array}{l}\text { Science of The } \\
\text { Total Environment }\end{array}$ & 2017 & $566-578$ & - & - & 590 & en \\
\hline $\begin{array}{l}\text { Mcowen, C., } \\
\text { Weatherdon, } \\
\text { L.n, Bochove, } \\
\text { J.W., Sullivan, } \\
\text { E., Blyth, S., } \\
\text { Zockler, C., } \\
\text { Stanwell- } \\
\text { Smith, D., } \\
\text { Kingston, N., } \\
\text { Martin, C., } \\
\text { Spalding, M., } \\
\text { Fletcher, S. }\end{array}$ & A global map of saltmarshes & Journal - Article & $\begin{array}{l}\text { Biodiversity Data } \\
\text { Journal }\end{array}$ & 2017 & - & - & - & 5 & en \\
\hline $\begin{array}{l}\text { Pakeman R.J., } \\
\text { Hewison R.L. } \\
\text { \& Lewis R.J. }\end{array}$ & $\begin{array}{l}\text { Drivers of species richness and } \\
\text { compositional change in Scottish } \\
\text { coastal vegetation }\end{array}$ & Journal - Article & $\begin{array}{l}\text { Applied } \\
\text { Vegetation } \\
\text { Science } \\
\end{array}$ & 2017 & 183-193 & - & - & - & en \\
\hline $\begin{array}{l}\text { Pakeman, } \\
\text { Robin J., } \\
\text { Hewison, } \\
\text { Richard L., } \\
\text { Lewis, Rob J. }\end{array}$ & $\begin{array}{l}\text { Drivers of species richness and } \\
\text { compositional change in Scottish } \\
\text { coastal vegetation }\end{array}$ & Journal - Article & $\begin{array}{l}\text { Applied } \\
\text { Vegetation } \\
\text { Science }\end{array}$ & 2017 & 183-193 & - & 2 & 20 & en \\
\hline $\begin{array}{l}\text { Pellegrino, D., } \\
\text { Schirpke, U., } \\
\text { Marino, D. }\end{array}$ & $\begin{array}{l}\text { How to support the effective } \\
\text { management of Natura } 2000 \text { sites? }\end{array}$ & Journal - Article & $\begin{array}{c}\text { Journal of } \\
\text { Environmental } \\
\text { Planning and } \\
\text { Management }\end{array}$ & 2017 & 383-398 & - & 3 & 60 & en \\
\hline $\begin{array}{l}\text { Prisco, I., } \\
\text { Berardi, C., } \\
\text { Acosta, A.T.R. }\end{array}$ & $\begin{array}{l}\text { Coastal dune vegetation in central } \\
\text { Campania: an insight on the } \\
\text { Natural Reserve "Foce Sele- } \\
\text { Tanagro" }\end{array}$ & Journal - Article & Plant Sociology & 2017 & $43-50$ & - & 2 & 54 & en \\
\hline $\begin{array}{l}\text { Silan, G., Del } \\
\text { Vecchio, S., } \\
\text { Fantinato, E., } \\
\text { Buffa, G. }\end{array}$ & $\begin{array}{l}\text { Habitat quality assessment through } \\
\text { a multifaceted approach: the case } \\
\text { of the habitat } 2130 * \text { in Italy }\end{array}$ & Journal - Article & Plant Sociology & 2017 & $13-22$ & - & 2 & 54 & en \\
\hline $\begin{array}{l}\text { Sperandii, M. } \\
\text { G., Prisco, I., } \\
\text { Stanisci, A., } \\
\text { Acosta, A.T.R. }\end{array}$ & $\begin{array}{l}\text { RanVegDunes - A random plot } \\
\text { database of Italian coastal dunes }\end{array}$ & Journal - Article & Phytocoenologia & 2017 & $231-232$ & - & 2 & 47 & en \\
\hline
\end{tabular}




\begin{tabular}{|c|c|c|c|c|c|c|c|c|c|}
\hline Stesevic, D. & $\begin{array}{l}\text { Distribution of alien species along } \\
\text { sand dune plant communities } \\
\text { zonation }\end{array}$ & Journal - Article & $\begin{array}{l}\text { Periodicum } \\
\text { Biologorum }\end{array}$ & 2017 & $239-249$ & - & 4 & 119 & en \\
\hline $\begin{array}{l}\text { Tomaselli, V., } \\
\text { Adamo, M., } \\
\text { Veronico, G., } \\
\text { Sciandrello, S., } \\
\text { Tarantino, C., } \\
\text { Dimopoulos, } \\
\text { P., Medagli, P., } \\
\text { Nagendra, H., } \\
\text { Blonda, P. }\end{array}$ & $\begin{array}{l}\text { Definition and application of } \\
\text { expert knowledge on vegetation } \\
\text { pattern, phenology, and seasonality } \\
\text { for habitat mapping, as exemplified } \\
\text { in a Mediterranean coastal site }\end{array}$ & Journal - Article & $\begin{array}{l}\text { Plant Biosystems - } \\
\text { An International } \\
\text { Journal Dealing } \\
\text { with all Aspects of } \\
\text { Plant Biology }\end{array}$ & 2017 & 887-899 & - & 5 & 151 & en \\
\hline $\begin{array}{l}\text { Vanden Borre } \\
\text { J., } \\
\text { SpanhoveaT. \& } \\
\text { Haestb B. }\end{array}$ & $\begin{array}{l}\text { Towards a mature age of remote } \\
\text { sensing for Natura } 2000 \text { habitat } \\
\text { conservation: poor method } \\
\text { transferability as a prime obstacle }\end{array}$ & Journal - Article & $\begin{array}{l}\text { Springer } \\
\text { International } \\
\text { Publishing }\end{array}$ & 2017 & $11-37$ & - & - & - & en \\
\hline $\begin{array}{l}\text { Veronico, G., } \\
\text { Sciandrello, S., } \\
\text { Medagli, P., } \\
\text { Tomaselli, V. }\end{array}$ & $\begin{array}{l}\text { Vegetation survey and plant } \\
\text { landscape mapping of the SCI } \\
\text { IT9140002 "Litorale Brindisino" } \\
\text { (Puglia, Southern Italy) }\end{array}$ & Journal - Article & Plant Sociology & 2017 & $89-106$ & - & 1 & 54 & en \\
\hline $\begin{array}{l}\text { Zhou, X.-Y., } \\
\text { Lei, K. \& } \\
\text { Meng, W., }\end{array}$ & $\begin{array}{l}\text { An approach of habitat degradation } \\
\text { assessment for characterization on } \\
\text { coastal habitat conservation } \\
\text { tendency }\end{array}$ & Journal - Article & $\begin{array}{l}\text { Science of The } \\
\text { Total Environment }\end{array}$ & 2017 & $618-623$ & & & $593-594$ & en \\
\hline $\begin{array}{l}\text { Zivkovic, L., } \\
\text { Biondi, E., } \\
\text { Pesaresi, S., } \\
\text { Lasen, C., } \\
\text { Spampinato, } \\
\text { G., Angelini, P. }\end{array}$ & $\begin{array}{l}\text { The third report on the } \\
\text { conservation status of habitats } \\
\text { (Directive 92/43/EEC) in Italy: } \\
\text { processes, methodologies, results } \\
\text { and comments }\end{array}$ & Journal - Article & Plant Sociology & 2017 & $51-64$ & - & 2 & 54 & en \\
\hline $\begin{array}{l}\text { Agrillo E., } \\
\text { Alessi N., } \\
\text { Jiménez-Alfaro } \\
\text { B., Casella L., } \\
\text { Angelini P., } \\
\text { Argagnon O., } \\
\text { Crespo G., } \\
\text { Fernandez } \\
\text { Gonzalez F., } \\
\text { Monteiro } \\
\text { Henriques T., } \\
\text { Silva Neto C., } \\
\text { Attorre F., }\end{array}$ & $\begin{array}{l}\text { The use of large databases to } \\
\text { characterize habitat types: the case } \\
\text { of Quercus suber woodlands in } \\
\text { Europe }\end{array}$ & Journal - Article & $\begin{array}{l}\text { Rendiconti Lincei. } \\
\text { Scienze Fisiche e } \\
\text { Naturali }\end{array}$ & 2018 & $283-293$ & - & 2 & 29 & en \\
\hline $\begin{array}{l}\text { Álvarez- } \\
\text { Martínez, J.-M, } \\
\text { Jiménez- } \\
\text { Alfaro, B., } \\
\text { Barquín, J., } \\
\text { Ondiviela, B., } \\
\text { Recio, M., } \\
\text { Silió-Calzada, } \\
\text { A., Juanes, J.- } \\
\text { A. }\end{array}$ & $\begin{array}{l}\text { Modelling the area of occupancy of } \\
\text { habitat types with remote sensing }\end{array}$ & Journal - Article & $\begin{array}{l}\text { Methods in } \\
\text { Ecology and } \\
\text { Evolution }\end{array}$ & 2018 & $580-593$ & - & 3 & 9 & en \\
\hline $\begin{array}{l}\text { Angelini, P., } \\
\text { Chiarucci, A., } \\
\text { Nascimbene, J., } \\
\text { Cerabolini, B.- } \\
\text { E.-L, Fratte, } \\
\text { M.-Dalle, } \\
\text { Casella, L. }\end{array}$ & $\begin{array}{l}\text { Plant assemblages and } \\
\text { conservation status of habitats of } \\
\text { Community interest (Directive } \\
\text { 92/43/EEC): definitions and } \\
\text { concepts }\end{array}$ & Journal - Article & $\begin{array}{l}\text { Ecological } \\
\text { Qustions }\end{array}$ & 2018 & $87-97$ & - & 3 & 29 & en \\
\hline
\end{tabular}




\begin{tabular}{|c|c|c|c|c|c|c|c|c|c|}
\hline $\begin{array}{l}\text { Angiolini, C., } \\
\text { Bonari, G., } \\
\text { Landi, M. }\end{array}$ & $\begin{array}{l}\text { Focal plant species and soil factors } \\
\text { in Mediterranean coastal dunes: An } \\
\text { undisclosed liaison? }\end{array}$ & Journal - Article & $\begin{array}{l}\text { Estuarine, Coastal } \\
\text { and Shelf Science }\end{array}$ & 2018 & $248-258$ & - & - & 211 & en \\
\hline $\begin{array}{l}\text { Bezzi, A., } \\
\text { Pillon, S., } \\
\text { Martinucci, D., } \\
\text { Fontolan, G. }\end{array}$ & $\begin{array}{l}\text { Inventory and conservation } \\
\text { assessment for the management of } \\
\text { coastal dunes, Veneto coasts, Italy }\end{array}$ & Journal - Article & $\begin{array}{l}\text { Journal of Coastal } \\
\text { Conservation }\end{array}$ & 2018 & $503-518$ & - & - & 22 & en \\
\hline $\begin{array}{l}\text { Bonari, G., } \\
\text { Acosta, A. } \\
\text { Teresa R., } \\
\text { Angiolini, C. }\end{array}$ & $\begin{array}{l}\text { EU priority habitats: rethinking } \\
\text { Mediterranean coastal pine forests }\end{array}$ & Journal - Article & $\begin{array}{l}\text { Rendiconti Lincei. } \\
\text { Scienze Fisiche e } \\
\text { Naturali }\end{array}$ & 2018 & 295-307 & - & 2 & 29 & en \\
\hline $\begin{array}{l}\text { Cabello, J., } \\
\text { Mairota, P., } \\
\text { Alcaraz- } \\
\text { Segura, D., } \\
\text { Arenas-Castro, } \\
\text { S., Escribano, } \\
\text { P., Leitao, P.J., } \\
\text { Martinez- } \\
\text { Lopez, J., } \\
\text { Regos, A., } \\
\text { Requena- } \\
\text { Mullor, J.M. }\end{array}$ & $\begin{array}{l}\text { Satellite Remote Sensing of } \\
\text { Ecosystem Functions: } \\
\text { Opportunities and Challenges for } \\
\text { Reporting Obligations of the EU } \\
\text { Habitats Directive }\end{array}$ & conferencePaper & $\begin{array}{l}\text { IGARSS } 2018 \text { - } \\
2018 \text { IEEE } \\
\text { International } \\
\text { Geoscience and } \\
\text { Remote Sensing } \\
\text { Symposium }\end{array}$ & 2018 & $\begin{array}{c}6604- \\
6607\end{array}$ & - & - & - & en \\
\hline $\begin{array}{l}\text { Campagnaro, } \\
\text { T., Trentanovi, } \\
\text { G., Sitzia, T. }\end{array}$ & $\begin{array}{l}\text { Identifying Habitat Type } \\
\text { Conservation Priorities under the } \\
\text { Habitats Directive: Application to } \\
\text { Two Italian Biogeographical } \\
\text { Regions } \\
\end{array}$ & Journal - Article & Sustainability & 2018 & $1-20$ & - & 4 & 10 & en \\
\hline $\begin{array}{l}\text { Carli, E. } \\
\text { Frondoni, R., } \\
\text { Pinna, M.S., } \\
\text { Bacchetta, G., } \\
\text { Fenu, G., Fois, } \\
\text { M., Marignani, } \\
\text { M., Puddu, S., } \\
\text { Blasi, C. }\end{array}$ & $\begin{array}{l}\text { Spatially assessing plant diversity } \\
\text { for conservation: A Mediterranean } \\
\text { case study }\end{array}$ & Journal - Article & $\begin{array}{l}\text { Journal for Nature } \\
\text { Conservation }\end{array}$ & 2018 & $35-43$ & - & - & 41 & en \\
\hline $\begin{array}{l}\text { Caro, C., Pinto, } \\
\text { R., Marques, J. } \\
\text { C. }\end{array}$ & $\begin{array}{l}\text { Use and usefulness of open source } \\
\text { spatial databases for the } \\
\text { assessment and management of } \\
\text { European coastal and marine } \\
\text { ecosystem services }\end{array}$ & Journal - Article & $\begin{array}{l}\text { Ecological } \\
\text { Indicators }\end{array}$ & 2018 & $41-52$ & - & - & 95 & en \\
\hline $\begin{array}{l}\text { Del Vecchio, } \\
\text { S., Fantinato, } \\
\text { E., Janssen, } \\
\text { J.A.M., Bioret, } \\
\text { F., Acosta, A., } \\
\text { Prisco, I., } \\
\text { Tzonev, R., } \\
\text { Marcenò, C., } \\
\text { Rodwell, J., } \\
\text { Buffa, G. } \\
\end{array}$ & $\begin{array}{l}\text { Biogeographic variability of } \\
\text { coastal perennial grasslands at the } \\
\text { European scale }\end{array}$ & Journal - Article & $\begin{array}{l}\text { Applied } \\
\text { Vegetation } \\
\text { Science }\end{array}$ & 2018 & $312-321$ & - & 2 & 21 & en \\
\hline $\begin{array}{l}\text { Delaney, A., } \\
\text { Stout, J.C. }\end{array}$ & $\begin{array}{l}\text { Principles of cross congruence do } \\
\text { not apply in naturally disturbed } \\
\text { dune slack habitats: Implications } \\
\text { for conservation monitoring }\end{array}$ & Journal - Article & $\begin{array}{l}\text { Ecological } \\
\text { Indicators }\end{array}$ & 2018 & $358-364$ & - & - & 93 & en \\
\hline
\end{tabular}




\begin{tabular}{|c|c|c|c|c|c|c|c|c|c|}
\hline $\begin{array}{l}\text { Ellwanger, } \\
\text { Götz, Runge, } \\
\text { Stephan, } \\
\text { Wagner, } \\
\text { Melanie, } \\
\text { Ackermann, } \\
\text { Werner, } \\
\text { Neukirchen, } \\
\text { Melanie, } \\
\text { Frederking, } \\
\text { Wenke, Müller, } \\
\text { Christina, } \\
\text { Ssymank, Axel, } \\
\text { Sukopp, Ulrich }\end{array}$ & $\begin{array}{l}\text { Current status of habitat } \\
\text { monitoring in the European Union } \\
\text { according to Article } 17 \text { of the } \\
\text { Habitats Directive, with an } \\
\text { emphasis on habitat structure and } \\
\text { functions and on Germany }\end{array}$ & Journal - Article & $\begin{array}{c}\text { Nature } \\
\text { Conservation }\end{array}$ & 2018 & $57-78$ & - & - & 29 & en \\
\hline $\begin{array}{l}\text { Friedrichs, M., } \\
\text { Hermoso, V., } \\
\text { Bremerich, V., } \\
\text { \& Langhans, S. } \\
\text { D. }\end{array}$ & $\begin{array}{l}\text { Evaluation of habitat protection } \\
\text { under the European Natura } 2000 \\
\text { conservation network - The } \\
\text { example for Germany }\end{array}$ & Journal - Article & PLOS ONE & 2018 & e0208264 & - & 12 & 13 & en \\
\hline $\begin{array}{l}\text { Garcia-Lozano, } \\
\text { C., Pintó, J. }\end{array}$ & $\begin{array}{l}\text { Current status and future } \\
\text { restoration of coastal dune systems } \\
\text { on the Catalan shoreline (Spain, } \\
\text { NW Mediterranean Sea) }\end{array}$ & Journal - Article & $\begin{array}{c}\text { Journal of Coastal } \\
\text { Conservation }\end{array}$ & 2018 & $519-532$ & - & 3 & 22 & en \\
\hline $\begin{array}{l}\text { Gigante, D., } \\
\text { Acosta, A. T. } \\
\text { R., Agrillo, E., } \\
\text { Armiraglio, S., } \\
\text { Assini, S., } \\
\text { Attorre, F., } \\
\text { Bagella, S., } \\
\text { Buffa, G., } \\
\text { Casella, L., } \\
\text { Giancola, C., } \\
\text { Giusso del } \\
\text { Galdo, G. P., } \\
\text { Marcenò, C., } \\
\text { Pezzi, G., } \\
\text { Prisco, I., } \\
\text { Venanzoni, R., } \\
\text { Viciani, D. }\end{array}$ & $\begin{array}{l}\text { Habitat conservation in Italy: the } \\
\text { state of the art in the light of the } \\
\text { first European Red List of } \\
\text { Terrestrial and Freshwater Habitats }\end{array}$ & Journal - Article & $\begin{array}{l}\text { Rendiconti Lincei. } \\
\text { Scienze Fisiche e } \\
\text { Naturali }\end{array}$ & 2018 & $251-265$ & - & 2 & 29 & en \\
\hline $\begin{array}{l}\text { Le Mauff, B., } \\
\text { Juigner, M., } \\
\text { Ba, A., Robin, } \\
\text { M., Launeau, } \\
\text { P., Fattal, P. }\end{array}$ & $\begin{array}{l}\text { Coastal monitoring solutions of the } \\
\text { geomorphological response of } \\
\text { beach-dune systems using multi- } \\
\text { temporal LiDAR datasets (Vendée } \\
\text { coast, France) }\end{array}$ & Journal - Article & Geomorphology & 2018 & $121-140$ & - & - & 304 & en \\
\hline $\begin{array}{l}\text { Lengyel, S., } \\
\text { Kosztyi, B., } \\
\text { Schmeller, D. } \\
\text { S., Henry, P. } \\
\text { Y., Kotarac, } \\
\text { M., Lin, Y. P., } \\
\text { Henle, K. }\end{array}$ & $\begin{array}{l}\text { Evaluating and benchmarking } \\
\text { biodiversity monitoring: Metadata- } \\
\text { based indicators for sampling } \\
\text { design, sampling effort and data } \\
\text { analysis }\end{array}$ & Journal - Article & $\begin{array}{l}\text { Ecological } \\
\text { Indicators }\end{array}$ & 2018 & $624-633$ & - & - & 85 & en \\
\hline $\begin{array}{l}\text { Malavasi, M., } \\
\text { Bartak, V., } \\
\text { Carranza, M.L., } \\
\text { Simova, P., } \\
\text { Acosta, A.T.R. }\end{array}$ & $\begin{array}{l}\text { Landscape pattern and plant } \\
\text { biodiversity in Mediterranean } \\
\text { coastal dune ecosystems: Do } \\
\text { habitat loss and fragmentation } \\
\text { really matter? }\end{array}$ & Journal - Article & $\begin{array}{c}\text { Journal of } \\
\text { Biogeography }\end{array}$ & 2018 & $\begin{array}{c}1367- \\
1377\end{array}$ & - & 6 & 45 & en \\
\hline
\end{tabular}




\begin{tabular}{|c|c|c|c|c|c|c|c|c|c|}
\hline $\begin{array}{l}\text { Marcenò, C, } \\
\text { Guarino, R, } \\
\text { Loidi, J, } \\
\text { Herrera, M, } \\
\text { Isermann, M, } \\
\text { Knollová, I, } \\
\text { Tichý, L, } \\
\text { Tzonev, RT, } \\
\text { Acosta, ATR, } \\
\text { FitzPatrick, U,, } \\
\text { Iakushenko, D, } \\
\text { Janssen, JAM, } \\
\text { Jiménez- } \\
\text { Alfaro, B, } \\
\text { Kącki, Z, } \\
\text { Keizer- } \\
\text { Sedláková, I, } \\
\text { Kolomiychuk, } \\
\text { V, Rodwell, JS, } \\
\text { Schaminée, } \\
\text { JHJ, Šilc, U, } \\
\text { Chytrý M. }\end{array}$ & $\begin{array}{l}\text { Classification of European and } \\
\text { Mediterranean coastal dune } \\
\text { vegetation }\end{array}$ & Journal - Article & $\begin{array}{l}\text { Applied } \\
\text { Vegetation } \\
\text { Science }\end{array}$ & 2018 & $533-559$ & - & 3 & 21 & en \\
\hline $\begin{array}{l}\text { Muñoz- } \\
\text { Reinoso, J.C. }\end{array}$ & $\begin{array}{l}\text { Doñana mobile dunes: what is the } \\
\text { vegetation pattern telling us? }\end{array}$ & Journal - Article & $\begin{array}{l}\text { Journal of Coastal } \\
\text { Conservation }\end{array}$ & 2018 & $605-614$ & - & 4 & 22 & en \\
\hline $\begin{array}{l}\text { Pennetta, M., } \\
\text { Corbelli, V., } \\
\text { Gattullo, V., } \\
\text { Nappi, R., } \\
\text { Brancato, } \\
\text { V.M., Gioia, D. }\end{array}$ & $\begin{array}{l}\text { Beach vulnerability assessment of } \\
\text { a protected area of the Northern } \\
\text { Campania coast (Southern Italy) }\end{array}$ & Journal - Article & $\begin{array}{l}\text { Journal of Coastal } \\
\text { Conservation }\end{array}$ & 2018 & $\begin{array}{c}1017- \\
1029\end{array}$ & - & 5 & 22 & en \\
\hline Rodwell, J.S. & $\begin{array}{l}\text { The UK National Vegetation } \\
\text { Classification }\end{array}$ & Journal - Article & Phytocoenologia & 2018 & $133-140$ & - & 2 & 48 & en \\
\hline $\begin{array}{l}\text { Sarika, M.A., } \\
\text { Christopoulou, } \\
\text { A.N., Zervou, } \\
\text { S.D., Zikos, } \\
\text { A.C. }\end{array}$ & $\begin{array}{l}\text { Vegetation units of wetland and } \\
\text { terrestrial habitats: the case study } \\
\text { of Spercheios River and Maliakos } \\
\text { Gulf (Sterea Ellas, Greece), a } \\
\text { Natura } 2000 \text { Site }\end{array}$ & Journal - Article & Hacquetia & 2018 & $189-220$ & - & 2 & 17 & en \\
\hline $\begin{array}{l}\text { Sperandii, } \\
\text { M.G., Prisco, } \\
\text { I., Acosta, } \\
\text { A.T.R. }\end{array}$ & $\begin{array}{l}\text { Hard times for Italian coastal } \\
\text { dunes: insights from a diachronic } \\
\text { analysis based on random plots }\end{array}$ & Journal - Article & $\begin{array}{l}\text { Biodiversity and } \\
\text { Conservation }\end{array}$ & 2018 & $633-646$ & - & 3 & 27 & en \\
\hline $\begin{array}{l}\text { Tordoni, E., } \\
\text { Napolitano, R., } \\
\text { Maccherini, S., } \\
\text { Da Re, D., } \\
\text { Bacaro, G. } \\
\end{array}$ & $\begin{array}{l}\text { Ecological drivers of plant } \\
\text { diversity patterns in remnants } \\
\text { coastal sand dune ecosystems } \\
\text { along the northern Adriatic } \\
\text { coastline }\end{array}$ & Journal - Article & $\begin{array}{l}\text { Ecological } \\
\text { Research }\end{array}$ & 2018 & $\begin{array}{c}1157- \\
1168\end{array}$ & - & 6 & 33 & en \\
\hline $\begin{array}{l}\text { Tsiripidis, I., } \\
\text { Xystrakis, F., } \\
\text { Kallimanis, A., } \\
\text { Panitsa, M., } \\
\text { Dimopoulos, P. }\end{array}$ & $\begin{array}{l}\text { A bottom-up approach for the } \\
\text { conservation status assessment of } \\
\text { structure and functions of habitat } \\
\text { types }\end{array}$ & Journal - Article & $\begin{array}{l}\text { Rendiconti Lincei. } \\
\text { Scienze Fisiche e } \\
\text { Naturali }\end{array}$ & 2018 & $267-282$ & - & 2 & 29 & en \\
\hline $\begin{array}{l}\text { Viciani, D., } \\
\text { Dell'Olmo, L., } \\
\text { Foggi, B., } \\
\text { Ferretti, G., } \\
\text { Lastrucci, L., } \\
\text { Gennai, M. }\end{array}$ & $\begin{array}{l}\text { Natura } 2000 \text { habitat of Mt. } \\
\text { Argentario promontory (southern } \\
\text { Tuscany, Italy) }\end{array}$ & Journal - Article & Journal of Maps & 2018 & $447-454$ & - & 2 & 14 & en \\
\hline $\begin{array}{l}\text { Wood, Claire } \\
\text { M., Bunce, } \\
\text { Robert G. H., } \\
\text { Norton, Lisa } \\
\text { R., Smart, } \\
\text { Simon M., } \\
\text { Barr, Colin J. }\end{array}$ & $\begin{array}{l}\text { Land cover and vegetation data } \\
\text { from an ecological survey of } \\
\text { \&quot;key habitat\&quot; } \\
\text { landscapes in England, 1992-1993 }\end{array}$ & Journal - Article & $\begin{array}{l}\text { Earth System } \\
\text { Science Data }\end{array}$ & 2018 & $899-918$ & - & 2 & 10 & en \\
\hline
\end{tabular}




\begin{tabular}{|c|c|c|c|c|c|c|c|c|c|}
\hline $\begin{array}{l}\text { Chefaoui, } \\
\text { R.M., Chozas, } \\
\text { S. }\end{array}$ & $\begin{array}{l}\text { Abandonment of traditional } \\
\text { saltworks facilitates degradation of } \\
\text { halophytic plant communities and } \\
<\text { i }>\text { Carpobrotus edulis }</ i> \\
\text { invasion }\end{array}$ & Journal - Article & $\begin{array}{l}\text { Applied } \\
\text { Vegetation } \\
\text { Science }\end{array}$ & 2019 & $444-453$ & - & 3 & 22 & en \\
\hline $\begin{array}{l}\text { Damgaard, C., } \\
\text { Nygaard, B., } \\
\text { Ejrnæs, R., } \\
\text { Bruus, M., } \\
\text { Strandberg, B., } \\
\text { Strandberg, M., } \\
\text { Timmermann, } \\
\text { A., Ehlers, B.K }\end{array}$ & $\begin{array}{l}\text { Has the frequency of invasive } \\
\text { higher plants stabilized? Results } \\
\text { from a long- term monitoring } \\
\text { program of Danish habitats. }\end{array}$ & Journal - Article & $\begin{array}{l}\text { Applied } \\
\text { Vegetation } \\
\text { Science }\end{array}$ & 2019 & $292-299$ & - & 2 & 22 & en \\
\hline $\begin{array}{l}\text { Del Vecchio, } \\
\text { S., Fantinato, } \\
\text { E., Silan, G., \& } \\
\text { Buffa, G. }\end{array}$ & $\begin{array}{l}\text { Trade-offs between sampling effort } \\
\text { and data quality in habitat } \\
\text { monitoring }\end{array}$ & Journal - Article & $\begin{array}{c}\text { Biodiversity and } \\
\text { conservation }\end{array}$ & 2019 & $55-73$ & - & 1 & 28 & en \\
\hline $\begin{array}{l}\text { Díez-Garretas, } \\
\text { B., Comino, O., } \\
\text { Pereña, J., } \\
\text { Asensi, A. }\end{array}$ & $\begin{array}{l}\text { Spatio-temporal changes (1956- } \\
\text { 2013) of coastal ecosystems in } \\
\text { Southern Iberian Peninsula (Spain) }\end{array}$ & Journal - Article & $\begin{array}{l}\text { Mediterranean } \\
\text { Botany }\end{array}$ & 2019 & $111-119$ & - & 1 & 40 & en \\
\hline $\begin{array}{l}\text { Drius, M., } \\
\text { Jones, L., } \\
\text { Marzialetti, F., } \\
\text { de Francesco, } \\
\text { M. C., Stanisci, } \\
\text { A., Carranza, } \\
\text { M. L. }\end{array}$ & $\begin{array}{l}\text { Not just a sandy beach. The multi- } \\
\text { service value of Mediterranean } \\
\text { coastal dunes }\end{array}$ & Journal - Article & $\begin{array}{l}\text { Science of The } \\
\text { Total Environment }\end{array}$ & 2019 & $\begin{array}{r}1139- \\
1155\end{array}$ & - & - & 668 & en \\
\hline $\begin{array}{l}\text { García- } \\
\text { Romero, L., } \\
\text { Delgado- } \\
\text { Fernández, I., } \\
\text { Hesp, P. A., } \\
\text { Hernández- } \\
\text { Calvento, L., } \\
\text { Hernández- } \\
\text { Cordero, A. I., } \\
\text { Viera-Pérez, } \\
\text { M. }\end{array}$ & $\begin{array}{l}\text { Biogeomorphological processes in } \\
\text { an arid transgressive dunefield as } \\
\text { indicators of human impact by } \\
\text { urbanization }\end{array}$ & Journal - Article & $\begin{array}{l}\text { Science of The } \\
\text { Total Environment }\end{array}$ & 2019 & $73-86$ & - & - & 650 & en \\
\hline $\begin{array}{l}\text { Lopes, C. L., } \\
\text { Mendes, R., } \\
\text { Caçador, I., \& } \\
\text { Dias, J. M. }\end{array}$ & $\begin{array}{l}\text { Evaluation of long-term estuarine } \\
\text { vegetation changes through } \\
\text { Landsat imagery }\end{array}$ & Journal - Article & $\begin{array}{l}\text { Science of The } \\
\text { Total Environment }\end{array}$ & 2019 & $512-522$ & - & - & 653 & en \\
\hline $\begin{array}{l}\text { Pätsch, R., } \\
\text { Bruchmann, I., } \\
\text { Schellenberg, J. } \\
\text { Meisert, A., } \\
\text { Bergmeier, E. }\end{array}$ & $\begin{array}{l}\text { Elytrigia repens co-occurs with } \\
\text { glycophytes rather than } \\
\text { characteristic halophytes in low- } \\
\text { growing salt meadows on the } \\
\text { southern Baltic Sea coast }\end{array}$ & Journal - Article & Biologia & 2019 & $385-394$ & - & 4 & 74 & en \\
\hline $\begin{array}{l}\text { Pinna, M. S., } \\
\text { Bacchetta, G., } \\
\text { Cogoni, D., } \\
\text { Fenu, G. }\end{array}$ & $\begin{array}{l}\text { Is vegetation an indicator for } \\
\text { evaluating the impact of tourism on } \\
\text { the conservation status of } \\
\text { Mediterranean coastal dunes? }\end{array}$ & Journal - Article & $\begin{array}{l}\text { Science of The } \\
\text { Total Environment }\end{array}$ & 2019 & $255-263$ & - & - & 674 & en \\
\hline $\begin{array}{l}\text { Rincón, V., } \\
\text { Velázquez, J., } \\
\text { Gutiérrez, J., } \\
\text { Sánchez, B., } \\
\text { Hernando, A., } \\
\text { García-Abril, } \\
\text { A., Santamaría, } \\
\text { T., Sánchez- } \\
\text { Mata, D. }\end{array}$ & $\begin{array}{l}\text { Evaluating European Conservation } \\
\text { Areas and Proposal of New Zones } \\
\text { of Conservation under the Habitats } \\
\text { Directive. Application to Spanish } \\
\text { Territories }\end{array}$ & Journal - Article & Sustainability & 2019 & 398 & - & 2 & 11 & en \\
\hline $\begin{array}{l}\text { Šilc, U., } \\
\text { Stešević, D., } \\
\text { Rozman, A., } \\
\text { Caković, D., } \\
\text { Küzmič, F. }\end{array}$ & $\begin{array}{l}\text { Alien Species and the Impact on } \\
\text { Sand Dunes Along the NE Adriatic } \\
\text { Coast }\end{array}$ & bookSection & $\begin{array}{l}\text { Impacts of } \\
\text { Invasive Species } \\
\text { on Coastal } \\
\text { Environments }\end{array}$ & 2019 & $113-143$ & - & - & 29 & en \\
\hline $\begin{array}{l}\text { Sperandii, M. } \\
\text { G., } \\
\text { Bazzichetto, } \\
\text { M., Acosta, A. } \\
\text { T. R., Barták, } \\
\text { V., Malavasi, } \\
\text { M. }\end{array}$ & $\begin{array}{l}\text { Multiple drivers of plant diversity } \\
\text { in coastal dunes: A Mediterranean } \\
\text { experience }\end{array}$ & Journal - Article & $\begin{array}{l}\text { Science of The } \\
\text { Total Environment }\end{array}$ & 2019 & $\begin{array}{l}1435- \\
1444\end{array}$ & - & - & 652 & en \\
\hline
\end{tabular}




\begin{tabular}{|c|c|c|c|c|c|c|c|c|c|}
\hline $\begin{array}{l}\text { Sperandii, M. } \\
\text { G., } \\
\text { Bazzichetto, } \\
\text { M., Gatti, F., \& } \\
\text { Acosta, A. T. } \\
\text { R. }\end{array}$ & $\begin{array}{l}\text { Back into the past: Resurveying } \\
\text { random plots to track community } \\
\text { changes in Italian coastal dunes }\end{array}$ & Journal - Article & $\begin{array}{l}\text { Ecological } \\
\text { Indicators }\end{array}$ & 2019 & $572-578$ & - & - & 96 & en \\
\hline $\begin{array}{l}\text { Torca, M., } \\
\text { Campos, J. A., } \\
\text { \& Herrera, M. }\end{array}$ & $\begin{array}{l}\text { Changes in plant diversity patterns } \\
\text { along dune zonation in south } \\
\text { Atlantic European coasts }\end{array}$ & Journal - Article & $\begin{array}{l}\text { Estuarine, Coastal } \\
\text { and Shelf Science }\end{array}$ & 2019 & $39-47$ & - & - & 218 & en \\
\hline $\begin{array}{l}\text { Torca, M., } \\
\text { Campos, J. A., } \\
\text { \& Herrera, M. }\end{array}$ & $\begin{array}{l}\text { Species composition and plant } \\
\text { traits of south Atlantic European } \\
\text { coastal dunes and other } \\
\text { comparative data }\end{array}$ & Journal - Article & Data in Brief & 2019 & $207-213$ & - & - & 22 & en \\
\hline
\end{tabular}

634

635

636 
The selection of keywords was carried out according to the PICO (Population-Intervention-Comparison-Outcome) strategy, which allows for highlighting thematic groups of words and identifying records for an overview (Higgins and Green, 2011).

An initial list of potential keywords for the components of the PICO (Population-Intervention-ComparisonOutcome) approach was developed from a list of reference articles on the topics. In our study, "Habitats Directive" was defined as "population", "conservation status" as "intervention", "methodology" as "comparison" and "management" as "outcome". From the first list of keywords, searches were made on the SciVerse Scopus database. New potential keywords identified during the literature search were added. This list of keywords was improved as the searches progressed using an iterative approach. After checking a first list of the records found, we highlighted keywords relevant to the literature search. We then checked the results of this new search and verified the inclusion or exclusion of pre-identified and new keywords. In a third step, we restarted the search from the new selection of keywords. Since the list of keywords may differ from one publication to another, we selected the most common keywords. The literature search is based on keywords and Bolean operators (AND, OR and NOT). Each keyword was inserted in a hierarchical manner, according to its relevance, and for each term added, we evaluated the relevance of the first 20 references obtained.

Our final database contained 225 records: 208 articles, 8 reports, 6 books, 2 theses and 1 conference paper (Appendix A). For each study, we recorded a number of information such as year of publication, type of records, type of research, country and biogeographic regions (Continental, Atlantic, Boreal, Mediterranean, Black sea) in which the studies were conducted. Several studies came from several biogeographic regions and/or countries, they were also taken into account and classified. We also sorted the records according to the scale they used to assess the conservation status : (1) at the scale of the Natura 2000 site; (2) or at the biogeographic scale. We then classified the coastal habitat types recognized by the Annex I of the Habitats Directive: Cliff, dune, stuary, Lagoon, Salt marshes, Salty steppes. Some studies took into account several habitat types, they were classified in accordance. In order to meet our two research objectives, we analyzed the content of the records selected to identify the most frequent words used in the record summaries (Tab. 1).

In order to examine the extent to which European countries have built their methodology to assess and monitor conservation status of coastal habitat, we have classified the typologies used to describe habitats: (1) CORINE biotope which is a catalog of identifiable biotopes, biotopes formed by flora and fauna in connection with a certain abiotic environment, with relationships between these various elements; (2) EUNIS which is a classification of natural, semi-natural and anthropogenic habitats of terrestrial and marine areas of Europe; (3) Natura 2000, i.e. the list of habitats of Community interest listed in Annex 1 of the Habitats Directive; (4) Phytosociology, i.e. the typology of syntaxons or taxonomic units of indeterminate rank (association, alliance, order, class and their subunits); (5) Corine Land Cover corresponding to a biophysical inventory of land use and its evolution. Several studies were based on different typologies and were classified accordingly.

The types of methods were also recorded for each publication, either quantitative or qualitative and analytical methods. Some studies used both approaches and were classified accordingly. We also classified the types of surveys to determine the field methods used: (1) mapping (field mapping and remote sensing); (2) floristic surveys; (3) Phytosociological surveys; (4) Landscape surveys; (5) Transect; (6) Quadrat. Some studies were based on several types of surveys and were classified accordingly. Finally, we recorded the context in which the study was conducted: (1) assessment; (2) monitoring.

Our second aim was to examine what parameters and categories have been taking into account by european countries to assess and monitor conservation status of coastal habitat. To address this issue we classified the records according to whether they dealt with the parameters recommended by the Habitats Directive (range, area, structure and functions, future prospects). For the parameter Structure and functions, we classified the criteria as follows: (1) Ecological erosion/ecological process; (2) Landscape fragmentation/plant landscape; (3) Plant communities composition; (4) Typical species; (5) Floristic composition; (6) Alien species; (7) Vegetation cover; (9) Functional traits. Some studies took into account several criteria and were also categorized consequently.

Finally, for the Future prospects parameter, we have classified the approaches as follows: (1) Typology, which consists of a list of threats observed in the field or that would be likely to alter the habitat in the long term; (2) Indexes used to quantify anthropogenic impacts; (3) Diachronic analyses to identify dynamic habitat trends; (5) Human pressures, which consists of identifying threats that are solely anthropogenic in origin; (7) Vulnerability is the assessment of the long-term vulnerability of the habitat; (8) Naturalness is the assessment of the naturalness of the habitat; (9) Artificialisation is the quantitative and qualitative assessment of the anthropogenic impacts of the habitat. Some studies have considered several criteria and have been categorized consequently. 
We also sorted our records according to the PICO (Population-Intervention-Comparator-Outcome) components. Our target population included records that focused on all applications of the Habitats Directive in assessing the conservation status and monitoring of habitats. In 1992, the European Union adopted the European Habitats Directive (92/43/EEC) recognizing the importance of habitat types and species to be conserved. A set of habitats that require specific conservation measures by Member States is listed in Annex I of the Directive. The list of habitats was compiled by experts who selected habitat types whose main concern is conservation under the European CORINE Biotopes Programme, recently reclassified in the EUNIS classification (Davies et al. 2004). The intervention component focused on the assessment of conservation status, defined as the assessment of the floristic, faunistic and functional state of the habitats defined in Annex 1 of the Habitats Directive (Evans and Arvela 2011). The Habitats Directive has defined 4 parameters to assess the conservation status of a typical habitat: range, area, structures and functions, future prospects. The "comparison" part focused on the methodologies used to evaluate the 4 parameters mentioned above. The "results" component focused on habitat management, assessment and monitoring.

We took into account records written in English, French, Spanish or Portuguese (when English keywords were at least mentioned in the title of the notice).

\section{References}

Davies, C. E., Moss, D., \& Hill, M. O., 2004. EUNIS habitat classification revised 2004. Report to: European Environment Agency-European Topic Centre on Nature Protection and Biodiversity, 127-143.

Evans, D., Arvela, M., 2011. Assessment and reporting under Article 17 of the Habitats Directive. Explanatory Notes \& Guidelines for the period 2007-2012. European Commission, Brussels.

Higgins, J.P., Green, S. (Eds.)., 2011. Cochrane handbook for systematic reviews of interventions (Vol. 4). John Wiley \& Sons. 
Table 1. Aim of the study, hypotheses, with respective categories and subcategories, and classes used in the literature review.
Hypotheses
Categories
Description
Sub-
categories
Aim

Aim 1. to examine the extent to which european countries have build their methodology to assess and monitor conservation status of coastal habitat

\begin{tabular}{|c|c|c|}
\hline $\begin{array}{c}\text { H1 - Typologies to } \\
\text { define "habitat" are } \\
\text { diversified }\end{array}$ & Typology & $\begin{array}{l}\text { Accuracy of the } \\
\text { "habitat" (sensu } \\
\text { biotope, sensu } \\
\text { floristico-ecologica }\end{array}$ \\
\hline
\end{tabular}

H2- The whole of coastal habitats are studied

Type of coastal
habitat

Biogeographica Biogeographical scale I region of the study

H3 - Conservation status are assessed at different scales

\section{Type of coastal} habitats studied

To track down what
typologies are used to

Accuracy of the
"habitat" (sensu
biotope, sensu
loristico-ecological)
Type of coastal
habitats studied
iogeographical scale
of the study

Accuracy scale in
assessing the
Spatial scale
conservation status
criteria

H4 - Types of methods and criterias used to assess conservation status are not standardized

$\begin{array}{ccc}\begin{array}{c}\text { Type of } \\ \text { research }\end{array} & \text { Type of contributions } & \begin{array}{r}\text { To } \\ \text { the } \\ \text { auth }\end{array} \\ & & \text { To } \\ \text { Types of } & \text { Methods used to } & \text { the } \\ \text { surveys } & \text { evaluate criterias } & \text { th } \\ & & \text { a }\end{array}$

Conservation
status Type of contributions
typologies are used to describe habitat types

To track down what habitat types are studied

To track down what biogeographical regions are concerned by studies on conservation status of costal habitats

To track down what scales are used to assess and monitor conservation status

To track down what are the type of research that authors used to assess conservation status

To track down what are the methods and tools that authors used to assess conservation status

To track down the purpose for which the authors assessed the conservation status
CORINE Biotope, EUNIS,

EUR 28, Phytosicology, CORINE LAND COVER

Cliff, Dune, Estuary, Salt marshes, Salty steppes, Lagoon

Alpine, Continental, Atlantic, Boreal, Mediterranean, Black sea

Natura 2000 site, Biogeography

Quantitative study, Qualitative and analytical approach

Mapping, Floristic relevés, Phytosociological relevés, Landscape relevés, Transect, Quadrat

by european countries to assess and monitor Aim 2. to examine what parameters a
conservation status of coastal habitat

\begin{tabular}{|c|c|c|c|c|c|}
\hline \multirow{6}{*}{$\begin{array}{l}\text { H5 - The research } \\
\text { geographically (per } \\
\text { european coutries) and } \\
\text { methodologically } \\
\text { changed along time }\end{array}$} & Range & $\begin{array}{c}\text { Range of habitat } \\
\text { within its } \\
\text { biogeographical area }\end{array}$ & - & $\begin{array}{l}\text { To track down how } \\
\text { assess the current and } \\
\text { potential distribution of } \\
\text { habitats within their } \\
\text { biogeographic region }\end{array}$ & \\
\hline & Area & Habitat area (in ha) & - & $\begin{array}{l}\text { To track down how } \\
\text { map areas of habitats }\end{array}$ & \\
\hline & \multirow{4}{*}{$\begin{array}{l}\text { Structure and } \\
\text { fonctions }\end{array}$} & \multirow{4}{*}{$\begin{array}{l}\text { Structure corresponds } \\
\text { to the physical } \\
\text { organization, the } \\
\text { arrangement of the } \\
\text { elements within the } \\
\text { habitat, its biotic } \\
\text { characteristics, its } \\
\text { environment (soil, } \\
\text { geomorphology, } \\
\text { macro and micro- } \\
\text { climate, etc.). }\end{array}$} & $\begin{array}{l}\text { Ecological } \\
\text { system }\end{array}$ & \multirow{4}{*}{$\begin{array}{l}\text { To track down hiw } \\
\text { assess the changes of } \\
\text { ecological process } \\
\text { landscape, vegetation } \\
\text { and Flora }\end{array}$} & $\begin{array}{c}\text { Ecological erosion, ecological } \\
\text { processus }\end{array}$ \\
\hline & & & Landscape & & $\begin{array}{c}\text { Landscape fragmentation } \\
\text { Plant landscape }\end{array}$ \\
\hline & & & $\begin{array}{l}\text { Vegetation } \\
\text { and } \\
\text { syntaxon }\end{array}$ & & Plant communitis composition \\
\hline & & & Flora & & $\begin{array}{c}\text { Typical species } \\
\text { Floristic composition }\end{array}$ \\
\hline
\end{tabular}


The function corresponds to the intrinsic functioning of Alien species the habitat, i.e. all the biological actions and Vegetation cover processes that occur naturally in the habitat and result from the interaction between all

Functionnal traits these compartments: exchanges.

\section{Typology}

Index

Prospective trends include criteria and

Prospective trends indicators to assess the long-term viability of a habitat
To track down how authors have beeargeting methods, threats types and environment quality
Methods

Threats

types

Environmen

tal quality
Diachronic analysis

Human pressures Natural pressures Vulnerability Naturalness Artificialization 
Appendix C. Typology and distribution of the number of publications concerning coastal habitats by biogeographic region and by European countries.

Table. C.1. List of coastal habitats that are considered in the records reviewed in this paper. According to the habitats of the European Environment Agency (2019), all coastal habitats have been studied. They have been grouped by major types of coastal habitats.

\begin{tabular}{llc}
$\begin{array}{l}\text { Habitat } \\
\text { types }\end{array}$ & Definitions & Number of publications \\
Cliff & $\begin{array}{l}\text { Vegetated sea cliffs of the Atlantic, Baltic, Mediterranean } \\
\text { and Macaronesian coasts }\end{array}$ & 70 \\
Dune & $\begin{array}{l}\text { Sea dunes of the Atlantic, North Sea, Baltic and } \\
\text { Mediterranean coasts }\end{array}$ & 181 \\
Lagoon & $\begin{array}{l}\text { Shallow coastal salt water of Atlantic, Black sea, Boreal, } \\
\text { Continental, Mediterranean and Macaronesian coasts }\end{array}$ & 50 \\
Estuary & $\begin{array}{l}\text { Atlantic and continental salt marshes and salt meadows } \\
\text { Salt marshes }\end{array}$ & Mediterranean and Atlantic salt marshes and salt meadows \\
Salty steppes & Salt and gypsum inland steppes & 52 \\
\hline
\end{tabular}


Fig. C.1. Distribution of the number of records among coastal habitat types within EU biogeographic regions: a) Atlantic, b) Boreal, c) Continental, d) Mediterranean, e) Black Sea. Papers covering several biogeographic regions ( 44 records) have been included here. There were no publications entirely confined to the Alpine, Macaronesian and Steppic biogeographical regions only. Nested circles allow to represent hierarchies and compare values. This visualization is particularly effective to show the proportion between elements through their areas and their position inside a hierarchical structure.

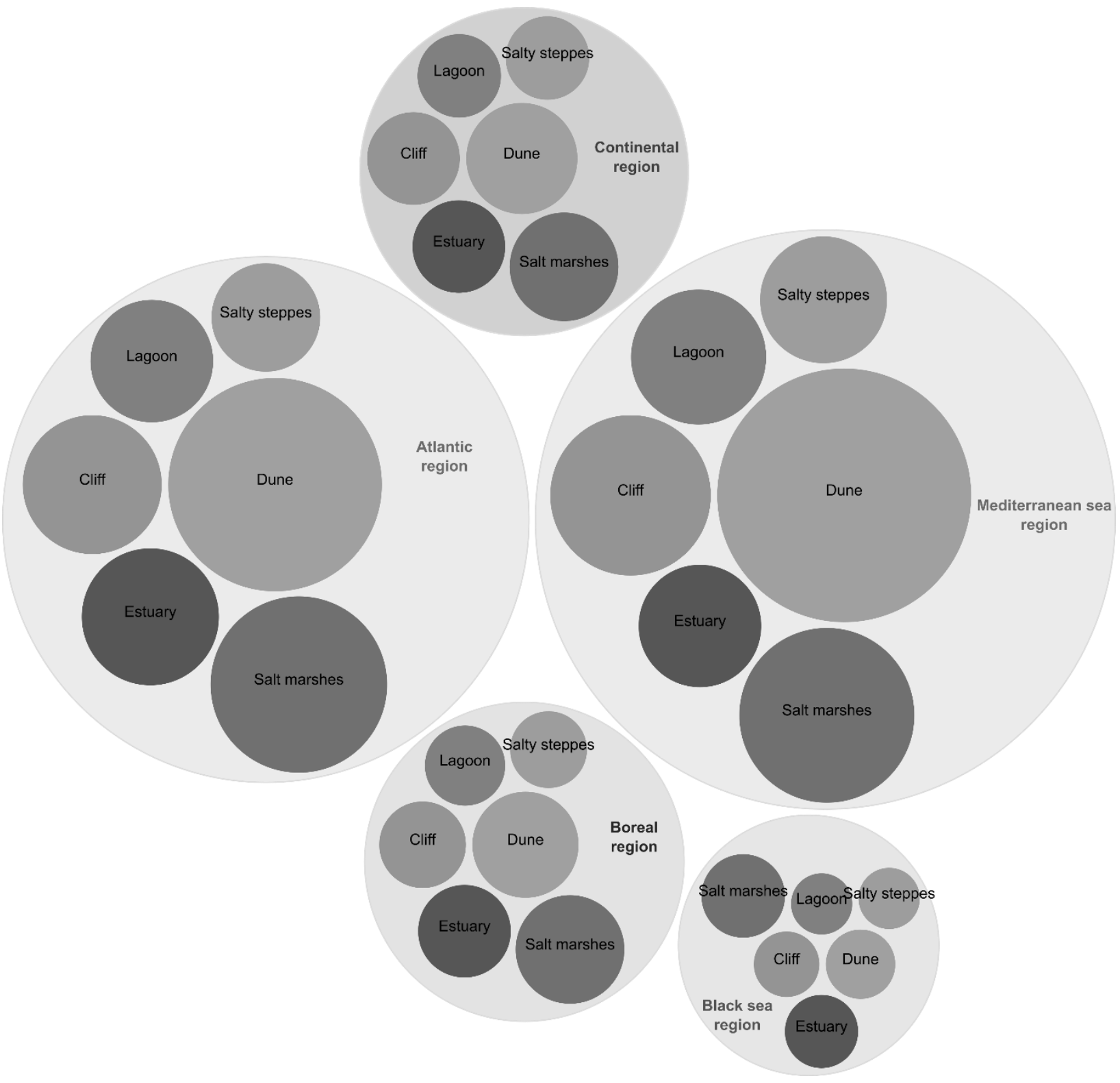

Fig. C.2. Distribution of the number of records among coastal habitat types by European country. Among European countries comprising coastal habitats, no publications were found in Romania, 
Bulgaria, Slovenia, Cyprus, Malta, Latvia and Lithuania. This bar chart presents grouped data with rectangular bars with heights proportional to the values that they represent.

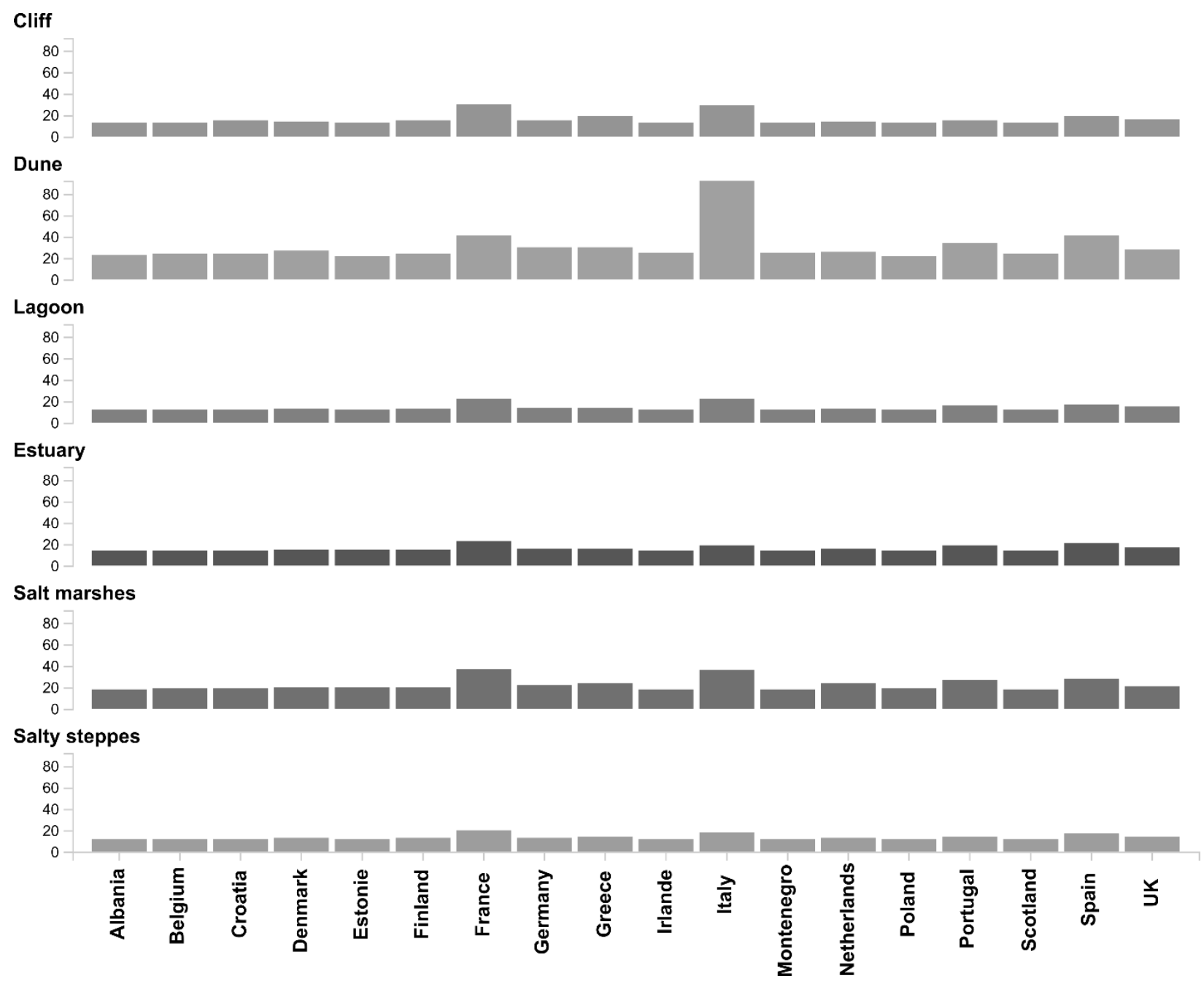

\section{References}

European Environment Agency (EEA), 2019. Welcome to EUNIS, the European Nature Information System. Available on : https://eunis.eea.europa.eu/. 


\section{Appendix D. Supplementary analysis}

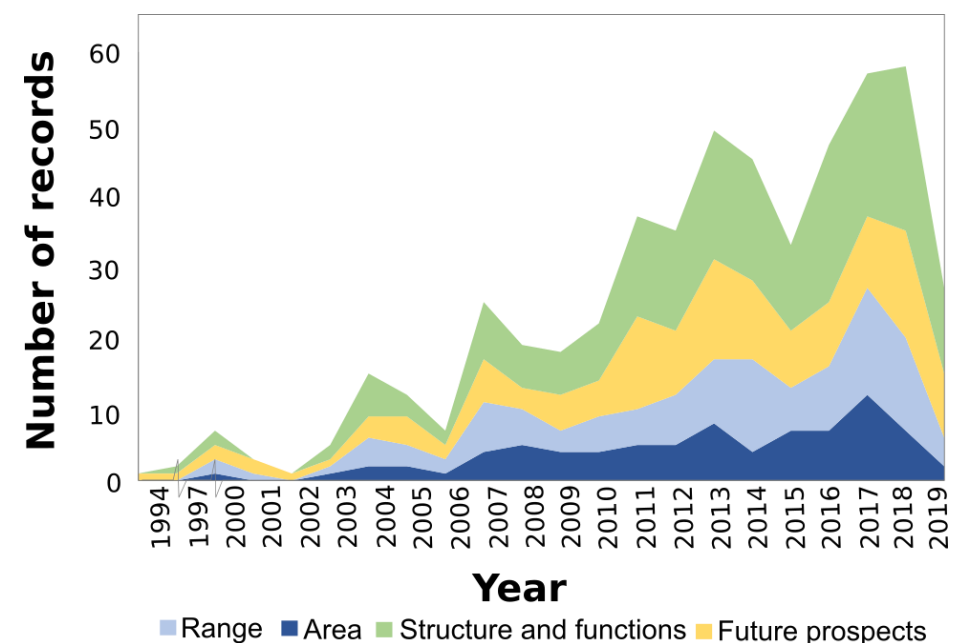

Fig. D.1. Temporal trends in the number of published records resulting from our search on parameters (Range, Area, Structure and functions, Future prospects) used to assess conservation status for coastal habitat. Emergence of steep increase of publications on four parameters since 2007. 


\section{Highlights}

- The implementation of HD remains complicated today to assess and monitor the conservation status.

- Methodological disparities exist between coastal habitats, between countries and between biogeographic regions.

- Currently, methodological approaches remain mainly based on expert judgments.

- Recent and innovative methods for automatic and objective modelling can help to assess habitat range and area.

- Concerted and multiscalar approaches can help to improve knowledge on structure, fonctions and future prospects. 